\title{
Vascular remodeling in pulmonary hypertension
}

Citation for published version (APA):

van Suylen, R. J. (1999). Vascular remodeling in pulmonary hypertension. [Doctoral Thesis, Maastricht University]. Universiteit Maastricht. https://doi.org/10.26481/dis.19990930rs

Document status and date:

Published: 01/01/1999

DOI:

10.26481/dis.19990930rs

Document Version:

Publisher's PDF, also known as Version of record

\section{Please check the document version of this publication:}

- A submitted manuscript is the version of the article upon submission and before peer-review. There can be important differences between the submitted version and the official published version of record.

People interested in the research are advised to contact the author for the final version of the publication, or visit the DOI to the publisher's website.

- The final author version and the galley proof are versions of the publication after peer review.

- The final published version features the final layout of the paper including the volume, issue and page numbers.

Link to publication

\footnotetext{
General rights rights.

- You may freely distribute the URL identifying the publication in the public portal. please follow below link for the End User Agreement:

www.umlib.nl/taverne-license

Take down policy

If you believe that this document breaches copyright please contact us at:

repository@maastrichtuniversity.nl

providing details and we will investigate your claim.
}

Copyright and moral rights for the publications made accessible in the public portal are retained by the authors and/or other copyright owners and it is a condition of accessing publications that users recognise and abide by the legal requirements associated with these

- Users may download and print one copy of any publication from the public portal for the purpose of private study or research.

- You may not further distribute the material or use it for any profit-making activity or commercial gain

If the publication is distributed under the terms of Article $25 \mathrm{fa}$ of the Dutch Copyright Act, indicated by the "Taverne" license above, 
Vascular remodeling in

pulmonary hypertension 
(C) van Suylen, Robert Jan, Maastricht 1999 ISBN 90-9012902-2

Vormgeving en druk: Datawyse | Universitaire Pers Maastricht 


\title{
Vascular remodeling in pulmonary hypertension
}

\author{
Proefschrift
}

ter verkrijging van de graad van doctor

aan de Universiteit Maastricht, op gezag van de Rector Magnificus, Prof. dr. A.C. Nieuwenhuijzen Kruseman volgens het besluit van het College van Decanen, in het openbaar te verdedigen op donderdag 30 september 1999 om 14.00 uur

door

Robert Jan van Suylen geboren te Prabumulih (Indonesië) 


\section{Promotores}

Prof. dr. M.J.A.P. Daemen

Prof. dr. J.F.M. Smits

Beoordelingscommissie

Prof. dr. J.G.R De Mey, voorzitter

Prof. dr. C.E. Blanco

Prof. dr. P.W. de Leeuw

Prof. dr. W.J. Mooi (Erasmus Universiteit Rotterdam)

Dr. G.J. Wesseling

Printing of this thesis was financially supported by the Netherlands Asthma Foundation and Boston Scientific. 
There's only one thing worse than losing a good fish-and that's losing someone else Adapted from: Trout and Salmon

$S$. Leventon (editor)

Voor Dorien, Maud, Puck en mijn ouders 



\section{Contents}

\section{CHAPTER 1}

General introduction $\quad 11$

1.1 Introduction 11

1.2 Normal pulmonary circulation 12

1.2.1 Structural differences between pulmonary and systemic circulation 13

1.2.2 Functional differences between pulmonary and systemic circulation 13

1.3 Pulmonary hypertension 13

1.3.1 Pulmonary hypertension in congenital heart disease $\quad 15$

1.3.2 Pulmonary hypertension in chronic obstructive pulmonary disease 16

1.4 Animal models of pulmonary hypertension 18

1.5 Humoral and cellular factors involved in pulmonary vascular remodeling 19

1.5.1 Environmental influences 19

1.5.2 Genetic influences 20

1.5.3 Changes in pulmonary artery composition during the development of pulmonary hypertension 21

1.5.4 The role of angiotensin II in pulmonary hypertension 22

1.5.5 The role of nitric oxide in pulmonary hypertension 24

1.6 Hypothesis 25

\section{CHAPTER 2}

Evaluation of pulmonary vascular hemodynamics and structure and their relation with clinical outcome in children with congenital heart disease 41

\section{CHAPTER 3}

Pulmonary artery remodeling differs in hypoxia- and monocrotaline-induced pulmonary hypertension $\quad 53$

\section{CHAPTER 4}

Dissociation of pulmonary vascular remodeling and right ventricular pressure in tissue ACE-deficient mice in conditions of chronic alveolar hypoxia $\quad 71$ 


\section{CHAPTER 5}

The DD genotype of the angiotensin converting enzyme gene is negatively associated with right ventricular hypertrophy in male patients with chronic obstructive pulmonary disease $\quad 83$

\section{CHAPTER 6}

Endothelial nitric oxide synthase gene polymorphisms and right ventricular hypertrophy in patients with chronic obstructive pulmonary disease $\quad 97$

\section{CHAPTER 7}

General discussion 109

Summary 119

Samenvatting 121

Dankwoord 125

Publications 127

Curriculum Vitae 128 


\section{List of abbreviations}

ACE Angiotensin I-converting-enzyme

AGT Angiotensinogen

AI Angiotensin I

AII Angiotensin II

ANP Atrial natriuretic peptide

ASD Atrial septal defect

CAVSD Complete atrioventricular septal defect

AT1 Angiotensin II-receptor type I

COPD Chronic obstructive pulmonary disease

eNOS Endothelial nitric oxide synthase

ET-I Endothelin I

$\mathrm{FEV}_{1} \quad$ Forced expiratory volume in one second

HIF-1 Hypoxia-inducible factor 1

$\mathrm{Hr} \quad$ Hematocrit

HIV Human immunodeficiency virus

iNOS Inducible nitric oxide synthase

LTOT Long-term oxygen therapy

$\mathrm{LV}+\mathrm{S} \quad$ Left ventricle and ventricular septum

MA/LA Ratio media area to lumen area

MCT Monocrotaline

MRVP Mean right ventricular pressure

nNOS Neuronal nitric oxide synthase

NO Nitric oxide synthase

PAP Pulmonary artery pressure

PAPVC Partial abnormal pulmonary venous connection

PCR Polymerase chain reaction

PDGF Platelet derived growth factor

PPH Primary pulmonary hypertension

RAS Renin-angiotensin-system

RV Right ventricle

TAPVC Total abnormal pulmonary venous connection

TGA Transposition of the great arteries

VEGF Vascular endothelial growth factor

VSD Ventricular septal defect 


\section{CHAPTER 1}

\section{General introduction}

\subsection{INTRODUCTION}

Pulmonary hypertension develops in response to a large variety of diseases (1). Regardless of its etiology, chronic pulmonary hypertension leads to structural alterations of the lung circulation, commonly called pulmonary vascular remodeling $(2,3)$. In the early phases of plexogenic arteriopathy, a characteristic form of pulmonary vascular remodeling frequently associated with congenital heart defects, and hypoxia-induced arteriopathy, these structural pulmonary vascular changes are quite similar, despite clear differences between the inciting mechanisms. In later stages of the remodeling process, increased pulmonary blood flow in patients with congenital heart disease or chronic alveolar hypoxia in patients with chronic obstructive pulmonary disease (COPD) may induce more disease specific structural patterns. A classic feature of the remodeling process in chronic hypoxia-induced pulmonary hypertension is muscularization of normally non-muscular arterioles and the presence of longitudinal smooth muscle cells in the intima of small pulmonary arteries $(4,5)$. Longstanding pulmonary hypertension in patients with COPD will lead to right ventricular dilatation and hypertrophy ('cor pulmonale') and may finally cause right ventricular failure $(6,7)$. The development of pulmonary hypertension is associated with an increased morbidity and mortality in patients with COPD (7-9).

In patients with a left-to-right shunt due to congenital heart disease the remodeling process is characterized by plexogenic arteriopathy $(10,11)$. In the early phase this type of remodeling is, like in hypoxia-induced pulmonary hypertension, characterized by medial hypertrophy and extension of smooth muscle cells into normally nonmuscular arterioles (12). In the more advanced stages intimal hyperplasia occurs, whereas plexiform intimal lesions have developed in the irreversible stage (13). It is believed that structural pulmonary vascular changes constitute an important determinant in the management and prognosis of children with congenital heart defects. Several studies, however, indicate important discrepancies berween pulmonary vascular structure and hemodynamic data in individual patients with a congenital heart defect $(12,14-17)$. This discrepancy may point to a lack of understanding of flow/structure relationships.

The pathogenesis of pulmonary vascular remodeling in patients with COPD and congenital heart defects is poorly understood. Pulmonary vascular remodeling is an active process that involves changes in several cellular processes like pulmonary vascular smooth muscle cell growth and migration, pulmonary vascular smooth muscle cell 
death, and production and degradation of extra-cellular matrix components (18). The pulmonary vasculature is capable of sensing changes within its milieu, integrating these signals via intercellular communications, and adapting through the local production of mediators that influence structure as well as function $(19,20)$. Especially the pulmonary endothelial cell, lining the inner vessel wall, is suited to detect changes in hemodynamic forces, such as shear stress and hydrostaric pressures, changes in $\mathrm{PO}_{2}$, vasoactive mediaturs and toxins. The variations in pulmonary vascular changes are probably explained by the rype and intensity of signals affecting endothelial cell function, the mediators generated by the endothelial cells, their effect on the pulmonary vascular smooth muscle cells and the underlying genetic predisposition of the patient. Geneticallydetermined differences in (pulmonary) vascular reactivity have been shown in animals and are likely to occur in man as well $(21,22)$. Polymorphisms of genes of mediators involved in vascular remodeling could be one of the explanations for these differences in susceptibility for the development of pulmonary hypertension. For instance, in the systemic circulation polymorphisms of genes of the renin angiotensin system (RAS) (23-32) and endothelial nitric oxide synthase (eNOS) (33-37) have been associated with an increased risk of cardiovascular diseases. With respect to the pulmonary circulation, only very few data exist about an association between gene polymorphism and the development of pulmonary hypertension.

This thesis aims at increasing insights into the mechanisms of pulmonary vascular remodeling, in 1 . children with congenital heart defects, 2 . two rat models and 3. a model of chronic hypoxia-induced pulmonary hypertension in genetically modified mice. We investigated the role of angiotensin II (AII) in this remodeling process, the correlation between pulmonary vascular remodeling and pulmonary artery pressure and the potential role of polymorphisms of genes of the RAS and ENOS in the development of pulmonary hypertension induced right ventricular hypertrophy in patients with severe COPD.

\subsection{NORMAL PULMONARY CIRCULATION}

The circulation of the lung is complex and differs both functionally and structurally from that in any other organ. The primary function of the pulmonary circulation is the exchange of oxygen and carbon dioxide and not nutrients as in most other organs. Optimal conditions for the exchange between blood and inspired air require a low pulmonary artery pressure. The normal mean pulmonary artery pressure is around 15 $\mathrm{mmHg}(38)$. Moreover, the pulmonary circulation is unique in that it receives the whole cardiac output, and in that it has the capaciry to adapt to an increase in cardiac output, without large alterations in pulmonary vascular pressure (39). Thus, the normal pulmonary circulation is characterized by a high flow, low pressure and low resistance. Compared to the systemic circulation it has unique structural and functional properties. 


\subsubsection{Structural differences between the pulmonary and systemic circulation}

The most important structural differences between the pulmonary and systemic circulation are: 1 . that for a given caliber, the medial thickness of pulmonary arteries is considerably less than that of systemic arteries and 2. that their lumina are relatively wider. These features reflect the high flow and low resistance in the pulmonary circulation. Arterioles similar to those in the systemic circulation are not present in the pulmonary circulation. In the acinus, a completely muscular pulmonary artery gives way to a partially muscular artery and finally becomes a non-muscular artery. This small non-muscular artery $(<90-100 \mu \mathrm{m},>10 \mu \mathrm{m})$, which is still larger than a capillary, is often referred to as arteriole or precapillary artery (40).

Also the capillary network of the lung differs from that of the systemic circulation (41). In peripheral organs the arterioles break down into a brush-like bundle of capillaries, which collect into a venule, whereas in the lung, capillaries form a dense anastomosing hexagonal network without an obvious beginning or end.

Apart from pulmonary arteries that accompany the bronchi there are additional branches known as supernumerary arteries, which do not follow the airways, but sharply bend off the main artery and head straight for the alveolar parenchyma (42).

Bronchial arteries originate from the systemic circulation and provide nutrient blood supply to the bronchi and major blood vessels. The media of bronchial arteries is thicker than that of pulmonary arteries, although slightly thinner than that of systemic arteries.

\subsubsection{Functional differences between the pulmonary and systemic circulation}

A major functional difference between the systemic and pulmonary circulation is the response to a decrease in $\mathrm{PO}_{2}$. In the systemic circulation, a local decrease in $\mathrm{PO}_{2}$ induces vasodilatation, allowing perfusion to increase and restore tissue $\mathrm{PO}_{2}$. In contrast, in the pulmonary circulation, a local decrease in $\mathrm{PO}_{2}$ induces vasoconstriction, causing a decreased perfusion and thereby restoring the ventilation/perfusion ratio.

Although the observation of hypoxia-induced pulmonary vasoconstriction is more than 50 years old, its biochemical mechanism remains largely unknown (43). It is now becoming clear that the endothelium of the lung vessels plays an important role in producing several different vasoactive substances like for instance AII, nitric oxide (NO) and endothelin I (ET-I) which not only play a role in modulating pulmonary vascular tone, but also in pulmonary vascular remodeling.

\subsection{PULMONARY HYPERTENSION}

Pulmonary hypertension is a frequent and serious, often fatal disorder. Clinical symptoms include dyspnoea on exertion, fatigue and angina-like pain. Pulmonary hyper- 
Table 1. - Causes of plexogenic and hypoxic arteriopathy.
Plexogenic arteriopathy
- Congenital cardiovascular disease with a:
- left-to-right shunt
- transposition with intact ventricular septum
- Hepatic disease, portal hypertension
- Schistosomiasis
- Anorexigens
- HIV infection
- Primary (unknown)
Hypoxic arteriopathy
- Chronic obstructive pulmonary disease
- Upper airway obstruction
- Alveolar hypoventilation
- on a central or
- neuromuscular basis
- Thoracic skeletal disorders
- High altitude

Adapted from Wagenvoort and Mooi $(10,178)$

tension is defined as mean pulmonary artery pressures in excess of $25 \mathrm{mmHg}$ at rest or in excess of $30 \mathrm{mmHg}$ during exercise (44).

Pulmonary hypertension can be the result of multiple and diverse etiologies which include congenital heart defects, chronic lung disease, autoimmune disease, HIV infection, hepatic disorders, thrombotic, pulmonary vasculitis, longstanding left ventricular failure, mitral valve stenosis/insufficiency, drugs, etc. Moreover, it can be a rapidly progressive and fatal illness of unexplained etiology (primary pulmonary hypertension $[\mathrm{PPH}])(45,46)$. All patients with longstanding pulmonary hypertension will have structural pulmonary vascular changes. However, depending on the etiology different structural patterns of pulmonary vascular lesions may develop. Plexogenic and hypoxic arteriopathy are two common patterns of pulmonary vascular remodeling. Their main causes are summarized in table 1.

If the primary etiology is known and the patient can be treared in time (correction of a congenital heart defect, etc) elevation of pulmonary artery pressure may regress. Estimates of survival in PPH are often poor, although considerable variation in these estimates does occur (47). Because it is out of the scope of this thesis to discuss all causes of pulmonary hypertension in detail we will focus on pulmonary hypertension in patients with congenital hearr defects and in patients with COPD, two common causes of pulmonary hypertension. 


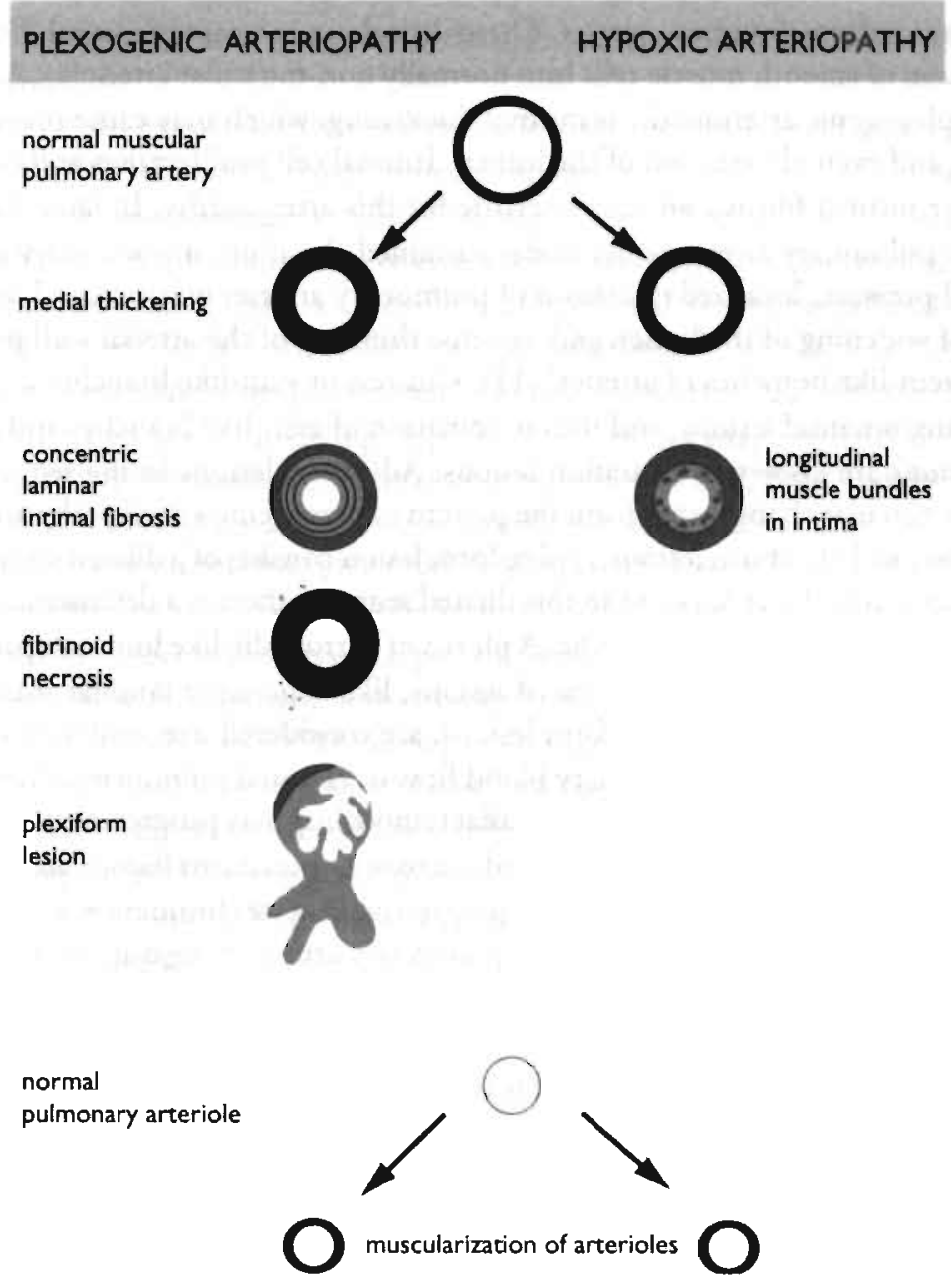

Figure 1.

\subsubsection{Pulmonary hypertension in congenital heart disease}

Plexogenic arteriopathy is a characteristic type of pulmonary vascular remodeling which may occur in congenital heart disease associated with an increased pulmonary blood flow. Plexogenic arteriopathy is a sequence of structural pulmonary arterial changes. In the final stage it includes the characteristic plexiform lesions (Figure 1) (48). This type of structural pulmonary vascular changes may also be found in conditions orher than increased pulmonary blood flow due to congenital heart disease. These conditions are summarized in table 1 . The first structural changes in patients with congenital heart disease associated with an increased pulmonary blood flow appear in 
the small muscular pulmonary arteries. These include an increase in medial thickness and extension of smooth muscle cells into normally non-muscular arterioles. Another feature of plexogenic arteriopathy is intimal thickening, which may cause progressive narrowing and even obliteration of the lumen. Intimal cell proliferation and concentric-laminar intimal fibrosis are characteristic for this arteriopathy. In later stages of plexogenic pulmonary arteriopathy, under sustained elevation of pulmonary arterial transmural pressure, localized dilatarion of pulmonary arteries may occur. The combination of widening of the lumen and extreme thinning of the arterial wall produce so called 'vein-like branches of arteries' (11). Clusters of vein-like branches are referred to as 'angiomatoid lesions' and the combination of vein-like branches and angiomatoid lesions are known as dilatation lesions. Advanced lesions in the sequence of pulmonary vascular changes that form the pattern of plexogenic arteriopathy are fibrinoid necrosis and plexiform lesions. A plexiform lesion consists of a dilated segment of a pulmonary artery. In or adjacent to this dilated segment there is a destruction of the arterial wall with thinning of the media. A plexus of narrow slit-like luminal spaces develops within a dilated lumen. Advanced lesions, like concentric laminar intimal fibrosis, fibrinoid necrosis and plexiform lesions, are considered irreversible (13).

As long as increased pulmonary blood flow or elevated pulmonary artery pressure persists, the process of pulmonary vascular remodeling may progress to irreversible structural vascular changes. When fibrinoid necrosis or plexiform lesions are present, plexogenic arteriopathy may even become progressive despite elimination of the cause (13). Histological evaluation of structural pulmonary artery changes in an open lung biopsy and hemodynamic evaluation by cardiac catheterization are two techniques commonly used to asses the stare of the pulmonary vasculature and to determine operability. The grading system described by Heath and Edwards is most commonly used to evaluate structural pulmonary changes in patients with a congenital heart defect (11). However, in individual patients with congenital heart disease, preoperative hemodynamic findings and postoperative clinical outcome do not always correlate with structural pulmonary artery changes $(14,16,17)$.

In summary, the pathophysiology of plexogenic arteriopathy in parients with congenital heart defects is poorly understood. Moreover, structural pulmonary vascular changes in patients with congenital heart disease do not always correlate with hemodynamic data.

\subsubsection{Pulmonary hypertension in COPD}

In 1946, Von Euler and Liljestrand were the first to report that a decrease in alveolar oxygen tension causes a rise in pulmonary arterial pressure (43). Since that time the effects of acute and chronic alveolar hypoxia on the pulmonary vasculature and the mechanisms mediating this effect have been extensively studied. Up till now, however, ir is nor completely clear which substances and cells are involved in the regula- 
tion of hypoxia-induced vasoconstriction. Potential candidates will be discussed in paragraph 1.5 .

Alveolar hypoxia occurs in a great variety of conditions which are summarized in table 1. COPD is by far the major cause of respiratory insufficiency in the industrialized countries and probably accounts for $90 \%$ of the cases of hypoxic pulmonary hypertension (49,50). As mentioned above alveolar hypoxia-induced vasoconstriction minimizes the blood flow to hypoxic areas. Blood is directed to better ventilated areas of the lungs, which restores the ventilation perfusion balance. However, if alveolar hypoxia becomes chronic and more generalized, as in patients with COPD, the combination of vasoconstriction and remodeling of pulmonary arteries may eventually cause severe pulmonary hypertension, right ventricular hypertrophy and, finally, right ventricular failure. Hypoxia-induced pulmonary arterial vasoconstricrion and remodeling are main factors responsible for this elevation of pulmonary artery pressure. Other factors like mechanical compression of blood vessels by a high alveolar pressure, loss of alveolar capillaries as occurs in emphysema, post-thromboric lesions, an increased hemarocrit and dysfunctional endothelium may be additional causes (51-54).

If patients with COPD develop pulmonary hypertension and overload of the right ventricle, they have developed a so called 'cor pulmonale', a descriptive term used to denote enlargement of the right ventricle by eirher hypertrophy, dilatation, or both, as a consequence of disorders and diseases of the respiratory system (55).

Alveolar hypoxia induces vasoconstriction but mainly in the small musculdr and pre-capillary arteries. As a consequence the most striking structural valsular ch.ınges reside in the small pulmonary arteries, al though functional as well as structural changes have been described in pulmonary veins (56-58). The most characteristic pulmonary vascular lesions in chronic hypoxic arteriopathy consist of an increased medial thickness of small muscular pulmonary arteries and peripheral extension of smooth muscle cells into normally non-muscular arterioles (muscularization of arterioles) (59). Another feature is the presence of longitudinal smooth muscle cells in the intima and sometimes in the media of arterioles. Small pulmonary veins may show similar changes although to a lesser extent. Large muscular arteries may show mild medial thickening (Figure 1).

Hypoxic pulmonary hypertension may be reversible when the oxygen content of the alveolar air is restored to normal, as has been shown in high-altitude dwellers during a stay at sea level (60). In rats, hypoxia-induced structural vascular changes disappear upon restoring normoxia $(61,62)$. Although pulmonary hypertension progresses slowly in patients with COPD, its presence implies a poor prognosis. The 5 -year survival rate is about $50 \%$ in most of the studies. In patients with COPD it is evident that most of the vasodilator trials are of marginal benefit (63). Long-term oxygen therapy (LTOT) may decrease pulmonary artery pressure (PAP) at rest and during exercise and can reverse the progression of pulmonary hypertension, although structural pulmonary changes and PAP rarely return to normal (64-66). LTOT can 
reduce mortality in parients with COPD, although this improvement in survival is not clearly associated with an improvement in pulmonary hemodynamics $(67,68)$.

\subsection{ANIMAL MODELS OF PULMONARY HYPERTENSION}

Much of the progress in understanding the mechanisms of chronic pulmonary hypertension comes from studies in animal models. Molecular and cellular biology rechniques have been successfully used to gain insights in pulmonary vascular biology (69). Especially pharmacological and generic interventions in these models may provide information on mediators and growth factors that play a crucial role in the regulation of the remodeling process of pulmonary arteries. Several animal models of pulmonary hypertension have been used like high pulmonary blood flow produced by systemic-to-pulmonary shunts, venous obstruction, lung injury and chronic embolic obstruction of the vessel lumen $(70,71)$. In this thesis we will focus on two classic models of pulmonary hypertension, the chronic hypoxia and monocrotaline (MCT) models.

\section{Chronic hypoxia}

High altitude-exposed $(4300 \mathrm{~m})$ calves and rats or rats exposed to chronic normobaric hypoxia $\left(10 \% \mathrm{O}_{2}\right)$ develop pulmonary hypertension and marked structural changes in small pulmonary arteries and arterioles that are comparable with those developing in humans under hypoxic conditions, and include right ventricular hypertrophy and an increased hematocrit. Longitudinal smooth muscle cells in the intima of small arteries, a classic feature of human hypoxic pulmonary vascular remodeling, however, has not been observed in chronic hypoxic rats. For this reason some authors believe that the rat is a poor animal model for the study of human pulmonary hypertension (72).

\section{Monocrotaline}

Metabolic pyrolles of monocrotaline (MCT) are known to cause inflammation of pulmonary vessels and endothelial damage (73-75). The net result is severe pulmonary hypertension, which develops within 4 weeks after the administration of a single dose of MCT (76). Structural pulmonary vascular changes resemble those described under hypoxic conditions (77). The development of longitudinal smooth muscle cells in the intima in this model has recently been described by Okada (78). However, these authors could only show this after performing an additional unilateral pneumectomy.

\section{Genetically altered mice}

Genetically altered mice in which the expression of genes is either suppressed or enhanced have recently been used to elucidate the mechanisms of pulmonary vascular remodeling. For instance, eNOS deficient mice show enhanced hypoxic pulmonary vascular remodeling, pulmonary hypertension and right ventricular hypertrophy 
$(79,80)$, indicating that $\mathrm{NO}$ plays a crucial role in the counterbalance mechanism of hypoxia-induced pulmonary hypertension and pulmonary artery remodeling. Chronic hypoxic mice partially deficient for hypoxia-inducible factor $1 \alpha$ show impaired physiological responses to chronic hypoxia (81).

Elevation of plasma atrial natriuretic peptide (ANP), a potent vasodilator, attenuates the development of pulmonary hypertension and right ventricular hypertrophy in rats exposed to chronic hypoxia $(82,83)$. Transgenic mice that overexpress ANP, also develop less pulmonary hypertension when exposed to chronic hypoxia compared to their nontransgenic littermates (84), showing the decisive role of ANP in the development of pulmonary hypertension.

\subsection{HUMORAL AND CELLULAR FACTORS INVOLVED IN PULMONARY VASCULAR REMODELING}

Chronic pulmonary hypertension is associated with changes in the production and release of porent vasoactive substances by the endothelium. Several vasoactive agents possess growth-regulatory properties. As already suggested above, pulmonary vascular remodeling may be the result of an imbalance of growth-inhibitory vasodilators and growth-promoting vasoconstrictors.

\subsubsection{Environmental influences}

A variety of signals, acting on specific receptor sites of the pulmonary endothelial cell, may alter the local production of mediators that influence pulmonary vascular structure as well as function (Figure 2). The endothelial cells seem to play a key role in maintaining the dynamic structure/function relation.

Signals that activate endothelial cells range from hemodynamic forces, like shear stress and hydrostatic pressures, to vasoactive mediarors and toxins (85).

Recent data indicate that shear stress activates a genetic program that alters the balance of mediators of remodeling by activating the transcription of genes of factors such as nitric oxide synthase, transforming growth factor $\beta 1$ and platelet-derived growth factor $(19,86,87)$. Also chronic hypoxia cin alter the expression of genes. Hypoxia causes an increase in the mRNA contents of the genes encoding for vascular endothelial growth factor (VEGF) and VEGF receptors in isolated perfused rat lung preparations (88). Hypoxia-inducible factor-1 (HIF-1) is a potential mediator of pulmonary vascular responses to hypoxia. HIF-1 is a transcription factor that is expressed in response to hypoxia and that activates expression of genes involved in erychropoiesis, angiogenesis, glycolysis, and modulation of vascular tone (81,89-92). Among the hypoxia-inducible genes that contain functionally important HIF-1 binding sites are those encoding VEGF (93), inducible NOS (91) and endothelin 1 (94). 


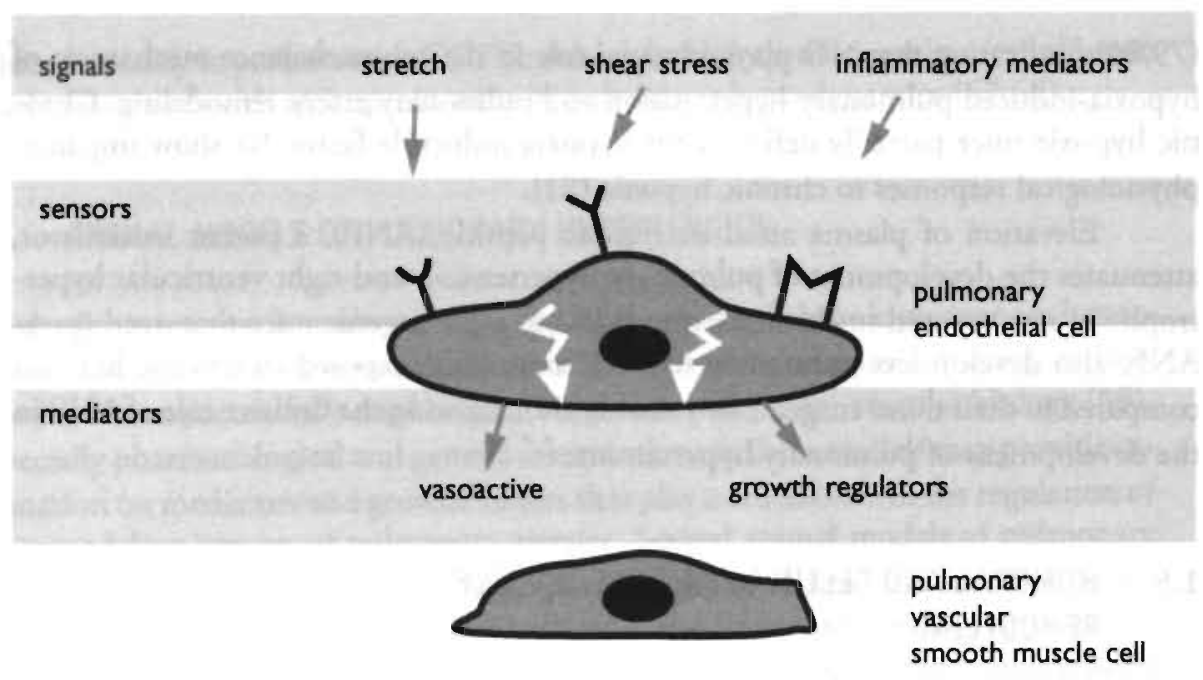

Figure 2. - Signals, sensors and mediators of vascular remodeling.

Although many mediators are known to play a role in the regulation of pulmonary vascular remodeling we will focus in this thesis on AII (paragraph 1.5.4) and NO (paragraph 1.5.5) because they are important examples of mediators with vasoconstrictive/growth promoring and vasodilarory/growth inhibitory properties respectively.

\subsubsection{Genetic influences}

Several studies indicare a generic component in the development of (primary) pulmonary hypertension. A familial form of PPH has been described and characterized with linkage to chromosome $2 \mathrm{q} 31-\mathrm{q} 32$, suggesting a genetic predisposition in some instances of PPH (95). Moreover, women are affected twice as often as men (96). An increased incidence of PPH associated with appetite-suppressant drugs has been described and raises the question whether these patients have a genetic predisposition to develop pulmonary hypertension (97). In genetically distinct strains of rats, differences in pulmonary vascular reactivity are a consequence of a different susceptibility to hypoxia $(98,99)$. A heterogeneous susceptibility to chronic hypoxia has also been described in human victims of chronic mountain sickness (22) and in cattle with Brisket disease (100). Some patients with COPD develop pulmonary hypertension and cor pulmonale whereas others do not. Again, this heterogeneity in susceptibility may be due to inherited differences in pulmonary vascular reactivity.

In the systemic circulation, recent studies have shown that polymorphisms of the renin angiotensin system (RAS) and eNOS are associated with a number of cardiovascular diseases. Polymorphisms of genes encoding for components of the renin angio- 
tensin system include, for instance, the $\mathrm{M}^{235} \mathrm{~T}$ polymorphism in the angiotensinogen gene, the 287-base-pair insertion (I) / deletion (D) polymorphism at intron 16 of the $\mathrm{ACE}$ gene and the $\mathrm{A}^{1166} \mathrm{C}$ polymorphism in the angiotensin II type 1 receptor gene. Polymorphisms of the eNOS gene include a 27-bp repeat polymorphism in intron 4 of the $\mathrm{eNOS}$ gene $(\mathrm{eNOS} \mathrm{a} / \mathrm{b}$ ) and a G894T polymorphism in exon 7 of the eNOS gene. The ACE DD genotype has been associated with left ventricular hypertrophy, increased risk of myocardial infarction, cardiomyopathy and coronary artery disease (23-27). Also polymorphisms in other genes of the renin angiotensin system, like the $\mathrm{M}^{235} \mathrm{~T}$ polymorphism in the angiotensinogen $(A G T)$ gene and the $\mathrm{A}^{1{ }^{16}{ }^{6} \mathrm{C} \text { polymor- }}$ phism in the angiotensin II type 1 receptor $\left(A G T_{1} R\right)$ gene have been associated with cardiovascular disease like essential hypertension, coronary heart disease and myocardial infarction (28-32). With respect to the pulmonary circulation one study reports that the ACE DD genotype is more prevalent in patients with PPH (101). However, Morrell and co-workers have shown that people living at high altitude and who develop hypoxia-induced pulmonary hypertension have a 6-fold higher frequency of the ACE II genotype compared with those without (102).

Polymorphisms of the eNOS gene could be another explanation for differences in susceptibility to develop pulmonary hypertension. As discussed in paragraph 1.5.5 alterations of eNOS gene expression in the lung may play a role in the pathogenesis of pulmonary hypertension. Individuals with the eNOS aa genotype have significantly higher levels of circulating plasma NO metabolites compared to individuals with the eNOS $a b$ and bb genotype (103) and may therefore be less susceptible to develop pulmonary hypertension. Like polymorphisms of the RAS genes, polymorphisms of the $\mathrm{NOS}$ gene have been associated with cardiovascular diseases. The $\mathrm{NOS}$ aa genotype has been associated with the development of coronary artery disease (33). The TT genotype of the eNOS gene G894T variant has been reported to be a strong risk factor for essential hypertension, myocardial infarction and coronary spasm (34-37). There are, however, no reports indicaring an associarion berween a/b and G894T polymorphisms of the eNOS gene and the development of pulmonary hypertension and/or right ventricular hypertrophy in patients with $\mathrm{PPH}$ or secondary pulmonary hypertension.

\subsubsection{Changes in pulmonary artery composition during the development of pulmonary hypertension}

The earliest structural changes in experimental models of pulmonary hypertension are found in the adventitia of pulmonary arteries. Adventitial fibroblasts proliferate, hypertrophy, increase the production of matrix proteins and convert into a contractile-like cell in response to hypoxia or mechanical stress (104-107). These structural changes of the adventitia may have functional effects on the ability of the pulmonary vasculature to respond to vasoconstrictor and vasodilator stimuli. Several studies have shown that vascular wall cells in adult organisms express genes or gene products cha- 
racteristic of earlier developmental states. In response to injury these include tropoelastin, fibronectin, tenascin, etc. (108-110). Moreover, genes such as those for smooth muscle-specific $\alpha$-actin, desmin or myosin are down-regulated when adult cells proliferate and migrate following injury $(111,112)$. Thus, a series of changes in smooth muscle cell phenotype occurs during the vascular remodeling process and also during pulmonary vascular remodeling. In the distal pulmonary vasculature, precursor cells differentiate into mature smooth muscle cells and migrate, so that normally non-muscular arterioles become abnormally muscular (113). In the more proximal vasculature, medial thickening of larger pulmonary arteries is caused by smooth muscle cell hypertrophy, hyperplasia and deposition of extracellular matrix components. A subset of vascular smooth muscle cells increase their replicating and matrix protein synthesizing properties (114-117). For instance, hypoxia selectively induces proliferation in a subset of (meta-vinculin-negative) cells in the bovine neonatal pulmonary arterial media (118). Smooth muscle cells of the media may differentiate into a more synthetic phenotype, producing extracellular matrix components, like elastin, collagen and glycoproteins (119-121). Finally, intimal proliferation occurs as a result of migration of smooth muscle cells from the media into the subintima, where they produce extracellular matrix components. In advanced plexogenic arteriopathy, proliferation of endothelial cells and collagen synthesis has been demonstrated within plexiform lesions $(121,122)$. Some studies have shown that activation of vascular elastase plays a role in the development of structural pulmonary artery changes (123). Fragmentation of the internal elastic lamina is one of the first structural events observed in pulmonary hypertension, which implies the activation of elastases in the pulmonary artery (124). Inhibition of elastase activity with serine elastase inhibitors has been shown to prevent or attenuate structural pulmonary vascular changes in both hypoxia- and MCT-induced pulmonary hypertension $(125,126)$.

Thus, in response to injury, pulmonary vascular wall cells express genes or gene products characteristic of earlier developmental states. A subset of vascular wall cells increases their replicating and matrix protein synthesizing properties and thus contribute to pulmonary vascular remodeling that characterizes chronic pulmonary hypertension.

\subsubsection{The role of angiotensin II (AII) in pulmonary hypertension}

An important function of the pulmonary vascular endothelium is the cleavage of circulating, inactive angiotensin $\mathrm{I}(\mathrm{AI})$ to the potent vasoconstrictor $\mathrm{AII}$, by the action of angiotensin I converting enzyme (ACE). It is known that the renin angiotensin system (RAS) is activated in PPH and secondary pulmonary hypertension $(127,128)$. The most important effects of AII in the pulmonary circulation are summarized in table 2. Apart from its vasoconstrictive action, AII is known to induce structural arterial changes, like matrix protein synthesis and smooth muscle cell hypertrophy and proliferation (129-132). Right ventricular ACE expression is upregulated during the deve- 


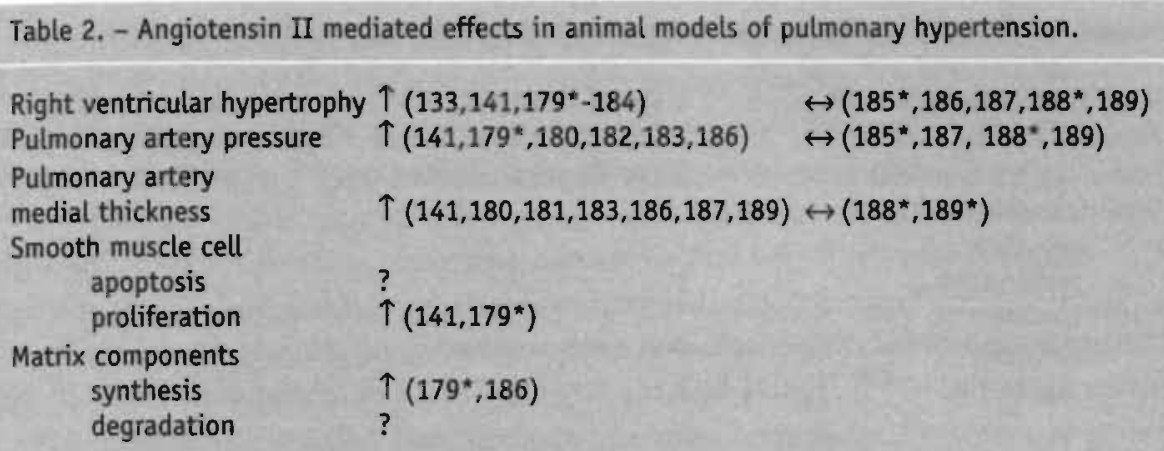

Studies in chronic hypoxia- and MCT * - induced pulmonary hypertension

lopment of hypoxia-induced right ventricular hypertrophy and may play a role in the pathogenesis of right ventricular hypertrophy secondary to hypoxic pulmonary hypertension (133). In animal models, most workers report a decrease in whole lung ACE activity during the development of pulmonary hypertension (77,134-137). Morrell and co-workers, however, showed thar ACE expression is increased in the wall of small pulmonary arteries during the development of hypoxic pulmonary hypertension (138). In addition, marked longitudinal variation in ACE expression along the normal vasculature was demonstrated. The highest ACE levels were found in small pulmonary arteries. Also in patients with $\mathrm{PPH}$ it has been shown that ACE immunoreactivity is markedly increased in the endothelium and subendothelial neointimal regions of pulmonary arteries compared to normal pulmonary arteries (139). Thus, local overproduction of AII by ACE could play an important role in pulmonary artery remodeling (140), probably via stimulation of proliferative activity of pulmonary smooth muscle cells (141). Borh ACE inhibitors and AT1 receptor blockers are known to attenuate the development of pulmonary hypertension, medial thickening of pulmonary arteries and right ventricular hypertrophy, especially in rats exposed to chronic hypoxia. In MCT induced pulmonary hypertension most studies show no effect of ACE inhibition or ATl receptor blockade on pulmonary vascular remodeling, right ventricular hypertrophy and PAP (see table 2).

In conclusion, there is increasing evidence that AII plays a crucial role in the development of hypoxia-induced pulmonary hypertension. Early intervention with ACE inhibitors could, in theory, prevent the development of pulmonary vascular remodeling and the advent of associated right heart failure. However, no improvement in functional capacity or survival has been demonstrated with ACE inhibitors in patients with COPD $(63,142-147)$, again showing the divergence between pulmonary vascular structure and function. 
Table 3. - NO mediated effects in animal models of pulmonary hypertension.

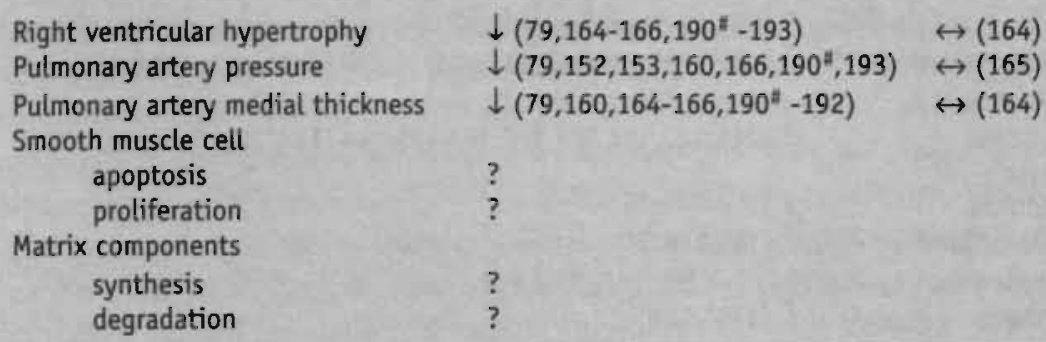

"Studies in both chronic hypoxia and MCT induced pulmonary hypertension

\subsubsection{The role of NO in pulmonary hypertension}

Nitric oxide is a potent vasodilator, which is synthesized from L-arginine by nitric oxide synthase (NOS) (148). There are three isoforms of NOS: neuronal constitutive nitric oxide synthase (nNOS), endothelial nitric oxide synthase (eNOS) and inducible nitric oxide synthase (iNOS) (148). The role of NO in the systemic circulation is well described. Its role in the pulmonary circulation, particularly in modulating the response to hypoxia is, however, less well documented. The most important effects of $\mathrm{NO}$ in the control of pulmonary vascular structure and function are summarized in table 3.

Under normal conditions, most studies report that basal NO production by pulmonary endothelial cells contributes to the maintenance of basal pulmonary vascular tone and is involved in the decline of the pulmonary vascular resistance during exercise $(149,150)$. Inhibition of the synthesis of NO markedly enhances the pulmonary pressor response to acure hypoxic challenges $(151,152)$. From these experiments it was concluded that an increased NO activity during acute hypoxia probably represents a physiological defence mechanism, limiting an excessive vasoconstrictive response of the pulmonary vasculature.

Studies in experimental animals and in humans have yielded contradictory results with respect to $\mathrm{NOS}$ expression under chronic hypoxic conditions. Endothelium-dependent pulmonary artery relaxation is impaired in rats exposed to chronic hypoxia and in patients with COPD $(54,153,154)$, suggesting reduced expression of eNOS. In patients with PPH and secondary pulmonary hypertension, however, both an increased and decreased expression of eNOS has been reported (155-157). In lungs of chronic hypoxic rats several studies have shown an increased expression of nNOS, eNOS and iNOS mRNA's (158-160). One study shows that in chronic hypoxia a rise in PAP is associated with continuing release of $N O(161)$. However, hypoxia decreases the expression of eNOS mRNA in human pulmonary endothelial cells in culture $(162,163)$. 
Mice with a congenital deficiency in the NOS gene show an enhanced pulmonary vascular remodeling, right ventricular hypertrophy and pulmonary hypertension as compared to wild-type animals indicating a pivotal (counterbalancing) role for $\mathrm{NO}$ in the development of hypoxia-induced pulmonary hypertension (79).

Chronic inhalation of NO attenuates pulmonary vascular remodeling in chronic hypoxic rats (164-166). The mechanism by which inhaled NO attenuates hypoxic remodeling is believed to be secondary to the decrease in PAP. NO itself is a vasodilator, but has also been shown to induce vasodilatation by inhibiting endothelial production of the potent vasoconstrictors ET-I and PDGF-B (167). An alternative explanation is that inhaled NO alters cellular mechanisms involved in pulmonary vascular remodeling. NO donors have been demonstrated to be antimitogenic in aortic vascular smooth muscle cell cultures (168-170). Attenuation of the muscularization of the pulmonary arterioles could be a result of a direct inhibitory effect on pulmonary artery smooth muscle cell growth. In humans, inhalation of NO has been shown to be beneficial in some but not all conditions complicated by elevated pulmonary vascular resistance (171-174). For instance, in COPD, where hypoxic vasoconstriction is important in maintaining the ventilation/perfusion matching, NO inhalation may worsen pulmonary gas exchange (175-177).

\subsection{HYPOTHESIS}

Our main hypothesis is that mediators that control the growth of pulmonary vascular smooth muscle cells are also involved in the development of pulmonary vascular remodeling in pulmonary hypertension.

From this main hypothesis we deduced the following sub-hypotheses:

1. Angiotensin II is an important mediator of vascular remodeling in pulmonary hypertension.

2. Vascular remodeling in pulmonary hypertension correlates with pulmonary artery pressure.

3. Polymorphisms of genes that contribute to vascular remodeling are risk factors for the development of pulmonary hypertension.

The role of AII in pulmonary vascular remodeling was studied in chapters 3 and 4. The correlation of pulmonary vascular structure and pulmonary artery pressure was investigated in chapter 2 (children with congenital heart disease), chapter 3 (chronic hypoxic and MCT treated rats) and chapter 4 (rissue ACE-deficient mice). The role of gene polymorphisms in the development of pulmonary hypertension in patients with COPD was investigated in chapter 5 ( $A C E I / D, A G T_{1} R A^{1166} C_{\text {and } A G T ~} M^{235} \mathrm{~T}$ ) and chapter 6 (eNOS G894T and $\mathrm{a} / \mathrm{b}$ ). In chapter 7 the data obtained in the studies will be discussed. 


\section{REFERENCES}

1. Wagenvoort CA, Mooi WJ. Physiology and pathophysiology of the pulmonary circulation. In: Biopsy pathology of the pulmonary vascularure. London: Chapman and Hall Medical, 1989.

2. Botney MD, Bahadori L, Gold LI. Vascular remodeling in primary pulmonary hyper tension. Potential role for transforming growth factor-beta. Am. J. Pathol 1994:144:286-295.

3. Rabinovitch M. Elastase, remodeling of extracellular matrix, and pulmonary hypertension. Semin. Respir. Crit. Care Med. 1994;15:199-205.

4. Hicken P, Heath D, Brewer DB, Whitaker W. The small pulmonary arteries in emphysema. J. Pathol. Bacteriol 1965;90:107-114.

5. Wagenvoort $C A$, Wagenvoort $N$. Hypoxic pulmonary vascular lesions in man at high altitude and in patients with chronic respiratory disease. Pathol. Microbiol. (Basel) 1973;39:276-282.

6. Fishman AP. State of the art: chronic cor pulmonale. Am. Rev. Respir. Dis. 1976;114:775-794.

7. Weitzenblum E, Hirth C, Ducolone A, Mirhom R, Rasaholinjanahary J, Ehrhart M. Prognostic value of pulmonary artery pressure in chronic obstructive pulmonary disease. Thorax 1981:36:752-758.

8. Boushy SF, Thompson HK, North LB, Beale AR, Snow TR. Prognosis in chronic obstructive pulmonary disease. Am. Rev. Respir. Dis. 1973;108:1373-1383.

9. Jandova R, Widimsky J, Nikodymova L. Long-term prognosis of pulmonary hypertension in chronic lung disease. In: Widimsky J, Herget J, Mlczoch J, eds. Pulmonary circulation in chronic lung disease; experimental and clinical approach. : Basal, New York, Karger, 1985.

10. Wagenvoort CA, Mooi WJ. Plexogenic arteriopathy. In: Biopsy pathology of the pulmonary vascularure. London: Chapman and Hall Medical, 1989.

11. Heath D, Edwards J. The pathology of hypertensive pulmonary vascular disease. A description of six grades of structural changes in the pulmonary arteries with special reference to congenital cardiac septal defects. Circulation 1958;18:533-547.

12. Rabinovitch M, Haworth SG. Castaneda AR, Nadas AS, Reid LM. Lung biopsy in congenital heart disease: a morphometric approach to pulmonary vascular disease. Circulation 1978;58:1107-1122.

13. Wagenvoort CA. Open lung biopsies in congenital heart disease for evaluation of pulmonary vascular disease. Predictive value with regard to corrective operability. Histopathology 1985:9:417-436.

14. Bush A, Busst CM, Haworth SG, Hislop AA, Knight WB, Corrin B, Shinebourne EA. Correlations of lung morphology, pulmonary vascular resistance, and outcome in children with congenital heart disease. Br. Heart J. 1988;59:480-485. 
15. Frescura C, Thiene G, Franceschini E, Talenti E, Mazzucco A. Pulmonary vascular disease in infants with complete atrioventricular septal defect. Int. J. Cardiol. 1987;15:91-103.

16. Haworth SG. Pulmonary vascular disease in ventricular sepral defect: Structural and functional correlations in lung biopsies from 85 patients, with outcome of intracardiac repair. J. Pathol. 1987;152:157-168.

17. Haworth SG. Pulmonary vascular bed in children with complete atrioventricular septal defect: Relation between structural and hemodynamic abnormalities. Am. J. Cardiol. 1986;57:833-839.

18. Stenmark KR, Mecham RP. Cellular and molecular mechanisms of pulmonary vascular remodeling. Annu. Rev. Physiol. 1997;59:89-144.

19. Resnick N, Gimbrone MA Jr. Hemodynamic forces are complex regulators of endothelial gene expression. Faseb J. 1995;9:874-882.

20. Gibbons GH, Dzau VJ. The emerging concept of vascular remodeling. N. Engl. J. Med. 1994;330:1431-1438.

21. Weir EK, Tucker A, Reeves JT, Will DH, Grover RF. The genetic factor influencing pulmonary hypertension in catcle at high alritude. Cardiovasc. Res. 1974;8:745-749.

22. Penaloza D, Sime F. Chronic cor pulmonale due to loss of altitude acclimatization (chronic mountain sickness). Am. J. Med.1971;50:728-743.

23. Busjahn A, Knoblauch H, Knoblauch M, Bohlender J, Menz M, Faulhaber HD, Becker A, Schuster H, Luft FC. Angiotensin-converting enzyme and angiotensinogen gene polymorphisms, plasma levels, cardiac dimensions. A twin study. Hypertension 1997;29:165-170.

24. Cambien F, Poirier O, Lecerf L, Evans A, Cambou JP, Arveiler D, Luc G, Bard IM, Bara L, Ricard S, Tiret L, Amouyel P, Alhenc-Gelas F, Soubrier F. Deletion polymorphism in the gene for angiotensin-converting enzyme is a potent risk factor for myocardial infarction. Nature 1992;359:641-644.

25. Raynolds MV, Bristow MR, Bush EW, Abraham WT, Lowes BD, Zisman LS, Taft CS, Perryman MB. Angiotensin-converting enzyme DD genotype in parients with ischaemic or idiopathic dilated cardiomyopathy. Lancet 1993;342:1073-1075.

26. Nakai K, Itoh C, Miura Y, Hotta K, Musha T, Itoh T, Miyakawa T, Iwasaki R, Hiramori $K$. Deletion polymorphism of the angiotensin I-converting enzyme gene is associated with serum ACE concentration and increased risk for CAD in the Japanese. Circulation 1994;90:2199-2202.

27. Schunkert H, Hense HW, Holmer SR, Stender M, Perz S, Keil U, Lorell BH, Riegger GA. Association between a deletion polymorphism of the angiotensin-convertingenzyme gene and left ventricular hypertrophy. N. Engl.J. Med. 1994;330:1634-1638.

28. Jeunemaitre X, Soubrier F, Kotelevtsev YV, Lifton RP, Williams CS, Charru A, Hunt SC, Hopkins PN, Williams RR, Lalouel JM, Corvol P. Molecular basis of human hypertension: role of angiotensinogen. Cell 1992;71:169-180. 
29. Bonnardeaux A, Davies E, Jeunemaitre X, Fery I, Charru A, Clauser E, Tirer L, Cambien F, Corvol P, Soubrier F. Angiorensin II type l recepror gene polymorphisms in human essential hyperension. Hypertension 1994;24:63-69.

30. Tiret L, Bonnardeaux A, Poirier O, Ricard S, Marques-Vidal P, Evans A, Arveiler D, Luc G, Kee F, Ducimetiere P, Soubrier F, Cambien F. Synergistic effects of angiotensinconverting enzyme and angiotensin-II type 1 recepror gene polymorphisms on risk of myocardial infarcrion. Lancet 1994:344:910-913.

31. Caulfield M, Lavender P, Farrall M, Munroe P, Lawson M, Turner P, Clark AJ. Linkage of the angiotensinogen gene to essential hypertension. N. Engl. J. Med. 1994;330:1629-1633.

32. Katsuya T, Koike G, Yee TW, Sharpe N, Jackson R, Norton R, Horiuchi M, Pratt RE, Dzau VJ, MacMahon S. Associacion of angiotensinogen gene T235 variant with increased risk of coronary hearr disease. Lancet 1995;345:1600-1603.

33. Wang XI, Sim AS, Badenhop RF, McCredie RM, Wilcken DE. A smoking-dependent risk of coronary artery disease associared with a polymorphism of the endothelial nitric oxide synthase gene. Nat. Med. 1996;2:41-45.

34. Hibi K, Ishigami T, Tamura K, Mizushima S, Nyui N, Fujita T, Ochiai H, Kosuge M, Watanabe Y, Yoshii Y, Kihara M, Kimura K, Ishii M, Umemura S. Endothelial nitric oxide synthase gene polymorphism and acute myocardial infarction. Hypertension 1998;32:521-526.

35. Miyamoto Y, Saito Y, Kajiyama N, Yoshimura M, ShimasakiY, Nakayama M, Kamitani S, Harada M, Ishikawa M, Kuwahara K, Ogawa E, Hamanaka I, Takahashi N, Kaneshige T, Teraoka H, Akamizu T, Azuma N, Yoshimasa Y, Yoshimasa T, Itoh H, Masuda $\mathrm{I}$, Yasue $\mathrm{H}$, Nakao K. Endothelial nitric oxide synthase gene is positively associated with essential hypertension. Hypertension 1998;32:3-8.

36. Shimasaki Y, Yasue H, Yoshimura M, Nakayama M, Kugiyama K, Ogawa H, Harada E, Masuda T, Koyama W, Saito Y, Miyamoro Y, Ogawa Y, Nakao K. Association of the missense Glu298Asp variant of the endothelial nitric oxide synthase gene with myocardial infarction. J. Am. Coll. Cardiol. 1998;31:1506-1510.

37. Yoshimura M, Yasue H, Nakayama M, Shimasaki Y, Sumida H, Sugiyama S, Kugiyama K, Ogawa H, Ogawa Y, Saito Y, Miyamoto Y, Nakao K. A missense Glu298Asp variant in the endothelial nitric oxide synthase gene is associated with coronary spasm in the Japanese. Hum. Genet. 1998;103:65-69.

38. Naeije R. Hypoxic pulmonary vasoconstriction in normal man [Thesis]. Free University of Brussels, 1983.

39. Reeves JT, Dempsey LA, Grover RF. Pulmonary circulation during exercise. In: Weir EK, Reeves JT, eds. Pulmonary Vascular Physiology and Physiopathology. New York: Marcel Dekker, 1989:107-33.

40. Reid L. The pulmonary circulation: remodeling in growth and disease. Am. Rev. Respir. Dis. 1979;119:531-546.

41. Weibel ER Morphomerry of the human lung. New York: Springer Verlag, Berlin and Academic Press, 1963. 
42. Ellior FM, Reid L. Some new facts about the pulmonary artery and its branching pattern. Clin. Radiol. 1965;16:193-198.

43. Euler US v, Liljestrand G. Observation on the pulmonary arterial blood pressure in the cat. Acta Physiol. Scand 1946;12:301-320.

44. Rubin LJ. Primary pulmonary hypertension. Chest 1993;104:236-250.

45. Rich S, Dantzker DR, Ayers SM, Bergofsky EH, Brundage BH, Detre KM, Fishman AP, Goldring RM, Groves BM, Koerner SK, Levy PC, Reid LM, Vreim CE, Williams GW. Primary pulmonary hypertension: a national prospective study. Ann. Intern. Med. 1987;107:216-223.

46. Dresdale DT, Schultz M, Michtom RJ. Primary pulmonary hypertension: I. Clinical and hemodynamic study. Am. J. Med. 1951;11:686-694.

47. D’Alonzo GE, Barst RJ, Ayres SM, Bergofsky EH, Brundage BH, Detre KM, Fishman AP, Goldring RM, Groves BM, Kernis JT, Levy PS, Pierra GG, Reid LM, Reefes JT, Rich S, Vreim CE, Williams GW, Wu M. Survival in patients with primary pulmonary hypertension. Results from a national prospective registry. Ann. Intern. Med. 1991;115:343-349.

48. Hatano S, Strasser T. Primary pulmonary hypertension. Report of Committee. World Health Organisation, Geneva. 1975.

49. Heath D, Smith P. Pulmonary vascular disease secondary to lung disease. In: Moser KM, ed. Pulmonary vascular disease. New York: Marcel Dekker Inc, 1979:387-426.

50. Reid LM. Chronic obstructive pulmonary disease. In: Fishman AP, ed. Pulmonary diseases and disorders. 2nd ed. New York: McGraw-Hill International Book CO, 1988:1247-72.

51. Harris P, Segel N, Green I, Housley E. The influence of the airways resistance and alveolar pressure on the pulmonary vascular resistance in chronic bronhciris. Cardiovasc. Res. 1968;2:84-92.

52. Segel N, Bishop JM. The circulation in patients with chronic bronchitis and emphysema at rest and during exercise, with special reference to the influence of changes in blond viscosity and blood volume on the pulmonary circulation. J. Clin. Invest. 1966; $45: 1555-1568$.

53. Harris $P$, Heath $D$. The human pulmonary circulation. Its form and function in health and disease. 3rd ed. Edinburgh: Churchill Livingstone, 1986.

54. Dinh-Xuan AT, Higenbottam TW, Clelland CA, Pepke-Zaba J, Cremona G, Butt AY, Large SR, Wells FC, Wallwork J. Impairment of endothelium-dependent pulmonaryartery relaxation in chronic obstructive lung disease. N. Engh J. Med. 1991;324:1539-1547.

55. Chronic cor pulmonale: Report of an expert commitree. Circulation 1963;27:594-615.

56. Zhao Y, Packer CS, Rhoades RA. Pulmonary vein contracts in response to hypoxia. Am. J. Physio.l1993;265:L87-L92.

57. Wagenvoort CA, Wagenvoort N. Pulmonary venous changes in chronic hypoxia. Virchows Arch. A. Pathol. Anat. Histol. 1976;372:51-56. 
58. Wagenvoort CA, Wagenvoort N. Pulmonary veins in high-altitude residents: a morphometric study. Thorax 1982;37:931-935.

59. Semmens M, Reid L. Pulmonary arterial muscularity and right ventricular hypertrophy in chronic bronchitis and emphysema. Br. J. Dis. Chest. 1974;68:253-263.

60. Penaloza D, Sime F, Banchero N, Gamboa R. Pulmonary hypertension in healthy man born and living at high altitudes. Medic. Thorac. 1962;19:449-456.

61. Abraham AS, Kay JM, Cole RB, Pincock AC. Haemodynamic and pathological study of the effect of chronic hypoxia and subsequent recovery of the heart and pulmonary vasculature of the rat. Cardiovasc. Res. 1971;5:95-102.

62. Heath D, Edwards C, Winson M, Smith P. Effects on the right ventricle, pulmonary vascularure, and carotid bodies of the rat of exposure to, and recovery from, simulated high altitude. Thorax 1973;28:24-28.

63. Klinger JR, Hill NS. Right ventricular dysfunction in chronic obstructive pulmonary disease. Evaluation and management. Chest 1991;99:715-723.

64. Wilkinson M, Langhorne CA, Heath D, Barer GR, Howard P. A pathophysiological study of 10 cases of hypoxic cor pulmonale. Q. J. Med. 1988;66:65-85.

65. Timms RM, Khaja FU, Williams GW. Hemodynamic response to oxygen therapy in chronic obstructive pulmonary disease. Ann. Intern. Med. 1985;102:29-36.

66. Weitzenblum E, Kessler R, Oswald M, Fraisse P. Medical treatment of pulmonary hypertension in chronic lung disease. Eur. Respir. J. 1994;7:148-152.

67. Medical Research Council Working Party. Long-term domiciliary oxygen therapy in chronic hypoxic cor pulmonale complicating chronic bronchitis and emphysema. Lancet 1981;1:681-686.

68. Nocturnal Oxygen Therapy Trial Group. Continuous or nocturnal oxygen therapy in hypoxemic chronic obstructive lung disease. Ann. Intern. Med. 1980;93:391-398.

69. Herger J. Animal models of pulmonary hypertension. Eur. Respir. Rev. 1993;3:559-563.

70. Rabinovitch M. Mechanisms of pulmonary hypertension in chronic high flow states. In: Weir EK, Reeves JT, eds. Pulmonary vascular physiology and pathophysiology. New York: Marcel Dekker, 1989:469-511.

71. Herget J, Palecek F. Experimental chronic pulmonary hypertension. Int. Rev. Exp. Pathol. 1978;18:347-406.

72. Heath $D$. The rat is a poor animal model for the study of human pulmonary hypertension. Cardioscience 1992:3:1-6.

73. Molteni A, Ward WF, Ts'ao C, Porr CD, Solliday NH. Monocrotaline-induced endothelial dysfunction in rats (41847). Proc. Soc. Exp. Bio.l Med. 1984;176:88-94.

74. Kay JM, Harris P, Heath D. Pulmonary hypertension produced in rats by ingestion of Crotalaria spectabilis seeds. Thorax 1967;22:176-179.

75. Sugita T, Hyers TM, Dauber IM, Wagner WW, McMurtry IF, Reeves JT. Lung vessel leak precedes right ventricular hypertrophy in monocrotaline-treated rats. J. Appl. Pbysiol 1983:54:371-374.

76. Meyrick B, Gamble W, Reid L. Development of Crotalaria pulmonary hypertension: hemodynamic and structural study. Am. J. Physiol. 1980;239:H692-H702. 
77. Kay JM, Keane PM, Suyama KL, Gauthier D. Angiotensin converting enzyme activin and evolution of pulmonary vascular disease in rats with monocroraline pulmonary hypertension. Thorax 1982;37:88-96.

78. Okada K, Tanaka Y, Bernstein M. Zhang W. Patterson G, Botney MD. Pulmunary hemodynamics modify the rat pulmonary artery response to injury. A neointimal model of pulmonary hypertension. Am. J. Pathol. 1997:151:1019-1025.

79. Steudel W, Scherrer-Crosbie M, Bloch KD, Weimann J, Huang PL. Jones RC, Picard $\mathrm{MH}$, Zapol WM. Sustained pulmonary hypertension and right ventricular hypertrophy after chronic hypoxia in mice with congenital deficiency of nitric oxide synthase 3 . J. Clin. Invest. 1998;101:2468-2477.

80. Steudel W, Ichinose F, Huang PL, Hurford WE, Jones RC, Bevan JA, Fishman MC, Zapol WM. Pulmonary vasoconstriction and hypertension in mice with rargeted disruption of the endothelial nitric oxide synthase (NOS 3) gene. Circ. Res. 1997;81:34-41.

81. Yu AY, Shimoda LA, Iyer NV, Huso DL, Sun X, McWilliams R, Beaty T, Sham JS, Wiener CM, Sylvester JT, Semenza GL. Impaired physiological responses to chronic hypoxia in mice partially deficient for hypoxia-inducible factor lalpha. J. Clin. Invest. 1999;103:691-696.

82. Jin HK, Yang RH, Thornton RM, Chen YF, Jackson R, Oparil S. Atrial natriuretic peptide lowers pulmonary arterial pressure in hypoxia-adapted rats. J. Appl. Physiol. 1988;65:1729-1735.

83. Jin H, Yang RH, Chen YF, Jackson RM, Oparil S. Atrial natriuretic pepride atrenuates the development of pulmonary hypertension in rats adapted to chronic hypoxia.J. Clin. Invest. 85:115-20.

84. Klinger JR, Petit RD, Curtin LA, Warburton RR, Wrenn DS, Steinhelper ME, Field LJ, Hill NS. Cardiopulmonary responses to chronic hypoxia in transgenic mice that overexpress ANP. J. Appl. Physiol. 1993;75:198-205.

85. Kolpakov V, Rekhter MD, Gordon D, Wang WH, Kulik TJ. Effect of mechanical forces on growth and matrix protein synthesis in the in vitro pulmonary artery. Analysis of the role of individual cell types. Circ. Res. 1995;77:823-831.

86. Langille BL. O'Donnel] F. Reductions in arterial diameter produced by chronic decreases in blood flow are endothelium-dependent. Science 1986;231:405-407.

87. Hsieh HJ, Li NQ. Frangos JA. Shear stress increases endorhelial platelet-derived growth factor mRNA levels. Am. J. Physiol. 1991;260:H642-H646.

88. Tuder RM, Flook BE, Voelkel NF. Increased gene expression for VEGF and the VEGF receptors KDR/FIk and Flt in lungs exposed to acute or to chronic hypoxia. Modulation of gene expression by nitric oxide. J. Clin. Invest. 1995:95:1793-1807.

89. Wang GL, Jiang BH, Rue EA. Semenza GL. Hypoxia-inducible factor 1 is a basic-helixloop-helix-PAS heterodimer regulated by cellular O2 tension. Proc. Natl. Acad. Sci. USA 1995;92:5510-5514. 
90. Yu AY, Frid MG, Shimoda LA, Wiener CM, Stenmark K, Semenza GL. Temporal, spatial, and oxygen-regulated expression of hypoxia-inducible factor-1 in the lung. $\mathrm{Am}$. J. Physiol. 1998;275:L818-L826.

91. Palmer LA, Semenza GL, Stoler MH, Johns RA. Hypoxia induces type II NOS gene expression in pulmonary artery endothelial cells via HIF-1. Am. J. Physiol. 1998;274:L212-L219.

92. Carmeliet P, Dor Y, Herbert JM, Fukumura D, Brusselmans K, Dewerchin M, Neeman M, Bono F, Abramovitch R, Maxwell P, Koch CJ, Ratcliffe P, Moons L, Jain RK, Collen D, Keshert E. Role of HIF-lalpha in hypoxia-mediated apoptosis, cell proliferation and tumour angiogenesis. Nature 1998;394:485-490.

93. Liu Y, Cox SR, Morita T, Kourembanas S. Hypoxia regulares vascular endorhelial growth factor gene expression in endothelial cells. Circ. Res. 1995;77:638-643.

94. Hu J, Discher DJ, Bishopric NH, Webster KA. Hypoxia regulates expression of the endothelin-1 gene through a proximal hypoxia-inducible factor-1 binding site on the antisense strand. Biochem. Biophys. Res. Commun. 1998;245:894-899.

95. Morse JH, Jones AC, Barst RJ, Hodge SE, Wilhelmsen KC, Nygaard TG. Mapping of familial primary pulmonary hypertension locus (PPH1) to chromosome 2q31-q32. Circulation 1997;95:2603-2606.

96. Loyd JE, Primm RK, Newman JH. Familial primary pulmonary hypertension: clinical patterns. Am. Rev. Respir. Dis. 1984;129:194-197.

97. Abenhaim L, Moride Y, Brenot F, Rich S, Benichou J, Kurz X, Higenbottam T, Oakley C, Wouters E, Aubier M, Simonneau G, Begaud B. Appetite-Suppressant Drugs and the Risk of Primary Pulmonary Hypertension. N. Engl. J. Med. 1996:335:609-616.

98. He LS, Chang SW, Voelkel NF. Pulmonary vascular reactivity in Fischer rats. J. Appl. Physiol. 1991;70:1861-1866.

99. Ou LC, Smith RP. Probable strain differences of rats in susceptibilities and cardioput monary responses to chronic hypoxia. Respir. Physiol. 1983;53:367-377.

100. Glover GH, Newsome IE. Brisket disease (dropsy of high altitudes). Colorado Agriculture Experimental Station Bulletin 1915;204.

101. Abraham WT, Raynolds MV, Gortschall B, Badesch DB, Wynne KM, Groves BM, Lowes BD, Bristow MR, Perryman MB, Voelkel NF. Importance of angiotensinconverting enzyme in pulmonary hypertension. Cardiology 1995;86 Suppl 1:9-15.

102. Morrell NW, Sarybaev AS, Alikhan A, Mirrakhimov MM, Aldashev AA. ACE genotype and risk of high altitude pulmonary hypertension in Kyrghyz highlanders. Lancet 1999;353:814.

103. Wang XI, Mahaney MC, Sim AS, Wang J, Wang J, Blangero J, Almasy L, Badenhop $\mathrm{RB}$, Wilcken DE. Genetic contribution of the endothelial constitutive nitric oxide synthase gene to plasma nitric oxide levels. Arterioscler. Thromb. Vasc. Biol. 1997;17:3147-3153.

104. Durmowicz AG, Parks WC, Hyde DM, Mecham RP, Stenmark KR. Persistence, re-expression, and induction of pulmonary arterial fibronectin, tropoelastin, and type I 
procollagen mRNA expression in neonatal hypoxic pulmonary hypertension. Am. J. Pathol. 1994;145:1411-1420.

105. Meyrick B, Reid L. Hypoxia and incorporation of $3 \mathrm{H}$-thymidine by cells of the rat pulmonary arteries and alveolar wall. Am. J. Pathol. 1979;96:51-70.

106. Meyrick B, Reid L. Hypoxia-induced structural changes in the media and adventitia of rat hilar pulmonary artery and their regression. Am. J. Pathol. 1980;100:151-178.

107. Stenmark KR, Fasules J, Hyde DM, Voelke! NF, Henson J, Tucker A, Wilson H, Reeves JT. Severe pulmonary hypertension and arterial adventitial changes in newborn calves at 4,300 m. J. Appl. Physiol 1987;62:821-830.

108. Hedin U, Holm J, Hansson GK. Induction of tenascin in rat arterial injury. Relationship to altered smooth muscle cell phenotype. Am. J. Pathol. 1991;139:649-656.

109. Kim DK, Zhang L, Dzau VJ, Pratt RE. H19, a developmentally regulated gene, is reexpressed in rat vascular smooth muscle cells after injury. J. Clin. Invest. 1994;93:355-360.

110. Li X, Tsai P, Wieder ED, Kribben A, Van Putten V, Schrier RW, Nemenoff RA. Vascular smooth muscle cells grown on Matrigel. A model of the contractile phenotype with decreased activation of mitogen-activated protein kinase. J. Biol. Chem. 1994;269:19653-19658.

111. Kocher O, Gabbiani G. Expression of actin mRNAs in rat aortic smoorh muscle cells during development, experimental intimal thickening, and culture. Differentiation 1986;32:245-251.

112. Kocher O, Skalli O, Bloom WS, Gabbiani G. Cytoskeleron of rat aortic smooth muscle cells. Normal conditions and experimental intimal thickening. Lab. Invest. 1984;50:645-652.

113. Meyrick B, Reid L. Ultrastructural findings in lung biopsy material from children with congenital heart defects. Am. J. Pathol. 1980;101:527-542.

114. Prosser IW, Stenmark KR, Suthar M, Crouch EC, Mecham RP, Parks WC. Regional heterogeneity of elastin and collagen gene expression in intralobar arteries in response to hypoxic pulmonary hypertension as demonstrated by in situ hybridization. Am. J. Pathol. 1989;135:1073-1088.

115. Stenmark KR, Dempsey EC, Badesch DB, Frid M, Mecham RP, Parks WC. Regulation of pulmonary vascular wall cell growth: developmental and site-specific heterogeneity. Eur. Respir. Rev. 1993:3:629-637.

116. Frid MG, Moiseeva EP, Stenmark KR. Multiple phenotypically distinct smooth muscle cell populations exist in the adult and developing bovine pulmonary arterial media in vivo. Circ. Res. 1994;75:669-681.

117. Frid MG, Dempsey EC, Durmowicz AG, Stenmark KR. Smooth muscle cell heterogeneity in pulmonary and systemic vessels. Importance in vascular disease: Arterioscler. Thromb. Vasc. Biol 1997;17:1203-1209.

118. Wohrley JD, Frid MG, Moiseeva EP, Orron EC, Belknap JK, Stenmark KR. Hypoxia selectively induces proliferation in a specific subpopulation of smooth muscle cells in the bovine neonatal pulmonary arterial media. J. Clin. Invest. 1995;96:273-281. 
119. Mecham RP, Stenmark KR, Parks WC. Connective tissue production by vascular smooth muscle in development and disease. Chest 1991;99:43S-47S.

120. Rabinovitch M. Investigational approaches to pulmonary hypertension. Toxicol. Pathol. 1991;19:458-469.

121. Botney MD, Liptay MJ, Kaiser LR, Cooper JD, Parks WC, Mecham RP. Active collagen synthesis by pulmonary arteries in human primary pulmonary hypertension. Am. J. Pathol. 1993;143:121-129.

122. Tuder RM, Groves B, Badesch DB, Voelkel NF. Exuberant endothelial cell growth and elements of inflammation are present in plexiform lesions of pulmonary hypertension. Am. J. Pathol. 1994;144:275-285.

123. Rabinovitch M. Elastase and the pathobiology of unexplained pulmonary hypertension. Chest 1998;114(Suppl):213S-224S.

124. Todorovich-Hunter L, Dodo H, Ye C, McCready L, Keeley FW, Rabinovitch M. Increased pulmonary artery elastolytic activity in adult rats with monocrotaline-induced progressive hypertensive pulmonary vascular disease compared with infant rats with nonprogressive disease. Am. Rev. Respir. Dis. 1992;146:213-223.

125. Ilkiw R, Todorovich-Hunter L, Maruyama K, Shin J, Rabinovitch M. SC-39026, a serine elastase inhibitor, prevents muscularization of peripheral arteries, suggesting a mechanism of monocrotaline-induced pulmonary hypertension in rats. Circ. Res. 1989;64:814-825.

126. Maruyama K, Ye CL, Woo M, Venkatacharya H, Lines LD, Silver MM, Rabinovitch M. Chronic hypoxic pulmonary hypertension in rats and increased elastolytic activity. $\mathrm{Am}$. J. Physiol. 1991;261:H1716-H1726.

127. Farber MO, Roberts LR, Weinberger MH, Robertson GL, Fineberg NS, Manfredi F. Abnormalities of sodium and $\mathrm{H} 2 \mathrm{O}$ handling in chronic obstructive lung disease. Arch. Intern. Med. 142:1326-30.

128. Ikram H, Maslowski AH, Nicholls MG, Espiner EA, Hull FT. Haemodynamic and hormonal effects of captopril in primary pulmonary hypertension. Br. Heart $J$. 1982;48:541-545.

129. Geisterfer AAT, Peach MJ, Owens GK. Angiotensin II induces hypertrophy, not hyperplasia, of cultured rat aorric smooch muscle cells. Circ. Res . 1988;62:749-756.

130. Gibbons GH, Pratt RE, Dzau VJ. Vascular smooth muscle cell hypertrophy vs. hyperplasia. Autocrine transforming growth factor-beta 1 expression determines growth response to angiotensin II. J. Clin. Invest. 1992;90:456-461.

131. Scott-Burden T. Hahn AWA, Resink TJ, Buhler FR. Modulation of extracellular matrix by angiotensin II: Stimulared glycoconjugate synthesis and growth in vascular smooth muscle cells. J. Cardiovasc. Pharmacol. 1990;16(Suppl. 4):S36-S41.

132. Chiu AT, Roscoe WA, McCall DE, Timmermans PB. Angiotensin II-1 receptors mediate both vasoconstrictor and hypertrophic responses in rat aortic smooth muscle cells. Receptor 1991;1:133-140. 
133. Morrell NW, Danilov SM, Satyan KB, Morris KG, Stenmark KR. Right ventricular angiotensin converting enzyme activity and expression is increased during hypoxic pulmonary hypertension. Cardiovasc. Res. 1997;34:393-403.

134. Keane PM, Kay JM, Suyama KL, Gaurhier D, Andrew K. Lung angiotensin converting enzyme activity in rats with pulmonary hypertension. Thorax 1982;37:198-204.

135. Caldwell RW, Blatteis CM. Effect of chronic hypoxia on angiotensin-induced pulmonary vasoconstriction and converting enzyme activity in the rat. Proc. Soc. Exp. Biol Med. 1983;172:346-350.

136. Jackson RM, Narkates AJ, Oparil S. Impaired pulmonary conversion of angiotensin I to angiotensin II in rats exposed to chronic hypoxia. J. Appl. Physiol 1986;60:1 121-1127.

137. Kay JM, Keane PM, Suyama KL, Gauthier D. Lung angiotensin converting enzyme activity in chronically hypoxic rats. Thorax 1985;40:587-591.

138. Morrell NW, Atochina EN, Morris KG, Danilov SM, Stenmark KR. Angiotensin converting enzyme expression is increased in small pulmonary arteries of rats with hypoxia-induced pulmonary hypertension. J. Clin. Invest. 1995;96:1823-1833.

139. Schuster DP, Crouch EC, Parks WC, Johnson T, Botney MD. Angiotensin converting enzyme expression in primary pulmonary hypertension. Am. J. Respir. Crit. Care Med. 1996;154:1087-1091.

140. Morishita R, Gibbons GH, Ellison KE, Lee W, Zhang L, Yu H, Kaneda Y, Ogihara T, Dzau VJ. Evidence for direct local effect of angiotensin in vascular hypertrophy. In vivo gene transfer of angiotensin converting enzyme. J. Clin. Invest. 1994;94:978-984.

141. Nong Z, Stassen J-M, Moons L, Collen D, Janssens S. Inhibition of tissue angiotensinconverring enzyme with quinapril reduces hypoxic pulmonary hypertension and pulmonary vascular remodeling. Circulation 1996;94:1941-1947.

142. Bertoli L, Lo Cicero S, Busnardo I, Rizzato G, Montanari G. Effects of captopril on hemodynamics and blood gases in chronic obstructive lung disease with pulmonary hypertension. Respiration 1986;49:251-256.

143. Zielinski J, Hawrylkiewicz I, Gorecka D, Gluskowski ], Koscinska M. Captopril effects on pulmonary and systemic hemodynamics in chronic cor pulmonale. Chest 1986;90:562-565.

144. Patakas D, Georgopoulos D, Rodini H, Christaki P. Effects of captopril in parients with chronic obstructive pulmonary disease and secondary pulmonary hypertension. Postgrad. Med. J. 1988;64:193-195.

145. Peacock AJ, Matthews A. Transpulmonary angiotensin II formation and pulmonary haemodynamics in stable hypoxic lung disease: the effect of captopril. Respir. Med. 1992;86:21-26.

146. Burke CM, Harte M, Duncan J, Connolly HM, Horgan JH, Theodore J, Callaghan B. Captopril and domiciliary oxygen in chronic aifflow obstruction. Br. Med. J. 1985;290:1251.

147. Pison CM, Wolf JE, Levy PA, Dubois F, Brambilla CG, Paramelle B. Effects of captopril combined with oxygen therapy at rest and on exercise in patients with chronic bronchitis and pulmonary hypertension. Respiration 1991;58:9-14. 
148. Moncada S, Higgs A. The L-arginine-nitric oxide pathway. N. Engl. J. Med. 1993;329:2002-2012.

149. Celermajer DS, Dollery C, Burch M, Deanfield JE. Role of endorhelium in the maintenance of low pulmonary vascular tone in normal children. Circulation 1994;89:2041-2044.

150. Stamler JS, Loh E, Roddy MA, Currie KE, Creager MA. Nitric oxide regulates basal systemic and pulmonary vascular resistance in healthy humans. Circulation 1994;89:2035-2040.

151. Robertson BE, Warren JB, Nye PC. Inhibition of nitric oxide synthesis potentiates hypoxic vasoconstriction in isolated rat lungs. Exp. Physiol. 1990;75:255-257.

152. Liu SF, Crawley DE, Barnes PJ, Evans TW. Endothelium-derived relaxing factor inhibits hypoxic pulmonary vasoconstriction in rats. Am. Rev. Respir. Dis. 1991;143:32-37.

153. Adnot S, Raffestin B, Eddahibi S, Braquet P, Chabrier PE. Loss of endotheliumdependent relaxant acrivity in the pulmonary circulation of rats exposed to chronic hypoxia. J. Clin. Invest. 1991;87:155-162.

154. Peinado VI, Barbera JA, Ramirez J, Gomez FP, Roca J, Jover L, Gimferrer JM, Rodriguez-Roisin R. Endothelial dysfunction in pulmonary arteries of patients with mild COPD. Am. J. Physiol. 1998;274:L908-L913.

155. Xue C, Johns RA. Endorhelial nitric oxide synthase in the lungs of parients with pulmonary hyperrension. N. Engl. J. Med. 1995;333:1642-1644.

156. Giaid A, Saleh D. Reduced expression of endothelial nitric oxide synthase in the lungs of patients with pulmonary hypertension. N. Engl. J. Med. 1995;333:214-221.

157. Mason NA, Springall DR, Burke M, PollockJ, Mikhail G, Yacoub MH, PolakJM. High expression of endothelial nitric oxide synthase in plexiform lesions of pulmonary hypertension. J. Pathol. 1998;185:313-318.

158. Shaul PW, North AJ, Brannon TS, Ujiie K, Wells LB, Nisen PA, Lowenstein CJ, Snyder $\mathrm{SH}$, Star RA. Prolonged in vivo hypoxia enhances nitric oxide synthase type I and type III gene expression in adult rat lung. Am. J. Respir. Cell. Mol. Biol. 1995;13:167-174.

159. Le-Cras TD, Xue C, Rengasamy A, Johns RA. Chronic hypoxia upregulates endothelial and inducible NO synthase gene and protein expression in rat lung. Am. J. Physiol. 1996;270:L.164-L170.

160. Xue C, Johns RA. Upregularion of nitric oxide synthase correlates temporally with onset of pulmonary vascular remodeling in the hypoxic rat. Hypertension 1996;28:743-753.

161. Zhao L, Crawley DE, Hughes JM, Evans TW, Winter RJ. Endothelium-derived relaxing factor acrivity in rat lung during hypoxic pulmonary vascular remodeling. $J$. Appl. Physiol. 1993;74(3):1061-5.

162. Ziesche R, Petkov V, Williams J, Zakeri SM, Mosgoller W, Knofler M, Block LH. Lipopolysaccharide and interleukin 1 augment the effects of hypoxia and inflammation in human pulmonary arterial tissue. Proc. Nat.l Acad. Sci. USA 1996;93:12478-12483. 
163. McQuillan LP, Leung GK, Marsden PA, Kostyk SK, Kourembanas S. Hypoxia inhibits expression of eNOS via transcriptional and postranscriptional mechanisms. Am.J. Physiol 1994;267:H1921-H1927.

164. Horstman DJ, Frank DU, Rich GF. Prolonged inhaled NO attenuates hypoxic, but not monocrotaline-induced, pulmonary vascular remodeling in rats. Anesth. Analg. 1998;86:74-81.

165. Roos CM, Frank DU, Xue C, Johns RA, Rich GF. Chronic inhaled nitric oxide: effects on pulmonary vascular endothelial function and pathology in rats. J. Appl. Physiol. $1996 ; 80: 252-260$.

166. Kouyoumdjian C, Adnot S, Levame M, Eddahibi S, Bousbaa H, Raffestin B. Continuous inhalation of ritric oxide protects against development of pulmonary hypertension in chronically hypoxic rars. J. Clin. Invest. 1994;94:578-584.

167. Kourembanas S, McQuillan LP, Leung GK, Faller DV. Nitric oxide regulates the expression of vasoconstrictors and growth factors by vascular endothelium under both normoxia and hypoxia. J. Clin. Invest. 1993;92:99-104.

168. Garg UC. Hassid A. Nitric oxide-generating vasodilators and 8-bromo-cyclic guanosine monophosphate inhibit mitogenesis and proliferation of cultured rat vascular smooth muscle cells. J. Clin. Invest. 1989;83:1774-1777.

169. Newby AC, Southgatc KM, Assender JW. Inhibition of vascular smooth muscle cell proliferation by endothelium-dependent vasodilarors. Herz 1992; 17:291-299.

170. Nakaki T, Nakayama M, Kato R. Inhibition by nitric oxide and nitric oxide-producing vasodilators of DNA synthesis in vascular smooth muscle cells. Eur. J. Phirmacol. 1990;189:347-353.

171. Sitbon O, Brenot F, Denjean A, Bergeron A, Parent F, Azarian R, Herve P, Raffestin B, Simonneau $G$. Inhaled nitric oxide as a screening vasodilator agent in primary pulmonary hypertension. A dose-response study and comparison with prostacyclin. Am. J. Respir. Crit. Care Med 1995;151:384-389.

172. Roberts JD, Polaner DM, Lang P, Zapol WM. Inhaled nitric oxide in persistent pulmonary hypertension of the newborn. Lancet 1992;340:818-819.

173. Kinsella JP, Neish SR, Shaffer E, Abman SH. Low-dose inhalation nitric oxide in persistent pulmonary hypertension of the newborn. Lancet 1992;340:819-820.

174. Adnot S, Kouyoumdjian C, Defouilloy C, Andrivet P, Sediame S, Herigault R, Fratacci $\mathrm{MD}$. Hemodynamic and gas exchange responses to infusion of acetylcholine and inhala rion of nitric oxide in parients with chronic obstructive lung disease and pulmonary hypertension. Am. Rev. Respir. Dis. 1993;148:310-316.

175. Curzen $N$, Archer $S$. Chronic lung disease and pulmonary hypertension: yes or no to NO? [editorial]. Thorax 1997;52:105-106.

176. Jones AT, Evans TW. NO: COPD and beyond. Thorax 1997:52 Suppl 3:S16-S21.

177. Barbera JA, Roger J, Rovira I, Higenbortam TW, Rodriguez-Roisin R. Worsening of pulmonary gas exchange with nitric oxide inhalation in chronic obstructive pulmonary disease. Lancet 1996;347:436-440. 
178. Wagenvoort CA, Mooi WJ. Hypoxic arteriopathy. In: Biopsy pathology of the pulmonary vasculature. London: Chapman and Hail Medical, 1989.

179. Okada K, Bernstein ML, Zhang W, Schuster DP', Botney MD. Angiotensin-converting enzyme inhibition delays pulmonary vascular neointimal formation.Am. J. Respir. Crit. Care Med. 1998;158:939-950.

180. Zhao L, Al-Tubuly R, Owji AA, Nunez DJR, Wilkins MR. Angiotensin II receptor expression and inhibirion in the chronically hypoxic rat lung. Br. J. Pharmacol. 1996; 119:1217--1222.

181. Molteni A, Ward WF, Ts'ao CH, Solliday NH. Monocrotaline-induced cardiopulmonary damage in rats: amelioration by the angiotensin-converting enzyme inhibitor CL242817. Proc. Soc. Exp. Biol. Med. 1986;182:483-493.

182. Kentera D, Susic D, Cvetkovic A, Djordjevic G. Effects of SQ 14.225, an orally accive inhibitor of angiotensin-converting enzyme, on hypoxic pulmonary hypertension and right ventricular hypertrophy in rats. Basic. Res. Cardiol. 1981;76:344t-351.

183. Zakheim RM, Matrioli L, Molteni A, Mullis KB, Bartley J. Prevention of pulmonary vascular changes of chronic alveolar hypoxia by inhibition of angiotensin I-converting enzynue in the rat. Lab. Invest. 1975;33:57-61.

184. Morrell NW, Morris KG, Stenmark KR. Role of angiotensin-converting enzyme and angiorensin II in development of hypoxic pulmonary hypertension. Am. J. Physiol. 1995;269:H1186-H1194.

185. Kreutz R, Fernandez-Alfonso MS, Ganten D, Paul M. Effect of losartan on right ventricular hypertrophy and cardiac angiotensin I-converting enzyme activity in pulmonary hypertensive rats. Clin. Exp. Hypertens. 1996;18:101-111.

186. McKenzie JC, Hung K, Matrioli L, Klein RM. Reduction in hypertension-induced protein synthesis in the rat pulmonary trunk after treatment with teprotide (SQ 20881) (41959). Proc. Soc. Exp. Biol. Med. 1984;177:377-382.

187. Clozel JP, Saunier C, Hartemann D, Fischli W. Effects of cilazapril, a novel angiotensin converting enzyme inhibitor, on the structure of pulmonary arteries of rats exposed to chronic hypoxia. J. Cardiovase. Pharmacol. 1991;17:36-40.

188. Cassis LA, Ripperoe PE, Soltis EE, Painter DJ. Firz R, Gillespie MN. Angiorensin II and monocrotaline-induced pulmonary hypertension: effect of losartan (DuP 753), a nonpeptide angiotensin type 1 receptor antagonist. J. Pharmatol. Exp. Ther. 1992;262:1168-1172.

189. van-Suylen RJ, Smits JFM, Daemen MJAP. Pulmonary artery remodeling differs in hypoxia- and monocrotaline induced pulmonary hypertension.Am.J. Respir. Crit. Care Med. 1998;157:1423-1428.

190. Mitani Y, Maruyama K, Sakurai M. Prolonged administration of L-arginine ameliorates chronic pulmonary hypertension and pulmonary vascular remodeling in rats. Circulation 1997;96:689-697.

191. Roberts JD Jr, Roberts CT, Jones RC, Zapol WM, Bloch KD. Continuous nitric oxide inhalation reduces pulmonary arterial strucrural changes, right ventricular hypertrophy, and growth retardation in the hypoxic newborn rac. Circ. Res. 1995;76:215-222. 
192. Le Cras TD, Tyler RC, Horan MP, Morris KG, Tuder RM, MeMurtry IF, Johns RA, Abman SH. Effects of chronic hypoxia and altered hemodynarnics on endorhelial nirric oxide synthase expression in the adult rat lung. J. Clin. Inwest. 1998;101:795-801.

193. Mathew R, Zeballos GA, Tun H, Gewiz MH. Role of nitric oxide and endothelin-1 in monocrotaline-induced pulmonary hypertension in rats. Cardiovasc. Res. 1995;30: $739-746$. 


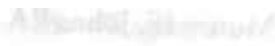

4. 1640

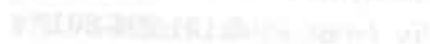

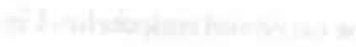

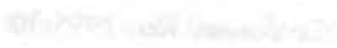


CHAPTER 2

Evaluation of pulmonary vascular hemodynamics and structure and their relation with clinical outcome in children with congenital heart disease 


\section{SUMMARY}

To determine the correlation between hemodynamics, structural pulmonary arterial changes and clinical outcome, we retrospectively studied hemodynamic and histological data and outcome in a group of 47 children with complex congenital heart disease.

Pulmonary artery pressures correlated weakly with increased muscularity of the pulmonary arterial tree $(r=0.46$ to $0.67 ; p<0.05)$ and with advanced plexogenic arteriopathy $(p<0.01)$. Diastolic pulmonary artery pressures lower than $25 \mathrm{mmHg}$ or pulmonary vascular resistances lower than $6 \mathrm{WU} . \mathrm{m}^{2}$ were never found in patients with features of advanced plexogenic arteriopathy. Perioperative mortality, associated with acute pulmonary hypertensive crises, correlated with increased arterial muscularity $(p=0.01)$, but not with advanced plexogenic arteriopathy. Pulmonary hypertensive crises did not correlate with preoperative hemodynamic parameters. Of 15 survivors, 5 showed persistent pulmonary hypertension at follow up ( $69 \pm 39$ months; mean \pm SD). However, no correlation existed between preoperative hemodynamic parameters or the histologic presence of advanced plexogenic arteriopathy and persistent pulmonary hypertension after surgery. All 3 patients with plexiform lesions showed persistent pulmonary hypertension $(p=0.02)$.

Conclusions: We found only limited correlations between hemodynamic data and pulmonary plexogenic arteriopathy. Perioperative mortality due to acute pulmonary hypertensive crises was associated with increased muscularity of the pulmonary arterial tree, but could not be predicted from preoperative hemodynamics or the presence of advanced plexogenic arteriopathy. Both hemodynamic and histologic assessment of plexogenic arteriopathy were of limited predictive value for persistent pulmonary hypertension after corrective surgery. Only plexiform lesions were predictive for persisting pulmonary hypertension. 


\section{INTRODUCTION}

Pulmonary plexogenic arteriopathy is thought to constitute a serious threat to children with congenital heart disease and increased pulmonary blood flow or increased pulmonary artery pressures. It is believed that as long as increased pulmonary bloodflow or elevated pressure in the pulmonary arteries persists, the process of plexogenic arteriopathy may progress towards a "point of no return", at which the process becomes irreversible and precludes a curative effect of surgical repair of the cardiac disease $(1,2)$. In Fontan or Norwood-like procedures, even a slight postoperative increase in the resistance of the pulmonary vascular bed will cause pulmonary hypoperfusion, which may easily result in clinical deterioration. The techniques most commonly used to assess the state of the pulmonary vasculature and to determine operability in children with congenital heart disease are hemodynamic evaluation by cardiac catheterization $(3,4)$ and histological evaluation of structural pulmonary vascular changes in an open lung biopsy $(1,5-7)$. However, important discrepancies between hemodynamic data and structural pulmonary vascular changes have been reported in individual patients with plexogenic arteriopathy $(6,8-11)$, hampering the interpretation of such findings. Furthermore, although widely used for over thirty years, data on the predictive value of both techniques with regards to outcome are scarce $(1,11-13)$. The purpose of the present study is to correlate structural pulmonary vascular changes and hemodynamic data, and relate the findings to clinical outcome in infants and children with complex congenital heart disease.

\section{METHODS}

Patients. 47 patients ( 29 male, 18 female) with congenital heart disease were included in this retrospective study. Hemodynamic and histological daca were obtained between 1983 and 1994.

Lung tissue specimens. Biopsy specimens were taken as an isolated procedure or during cardiac surgery in children (biopsy group). In addition, specimens taken at autopsy were included in the study (auropsy group). Lung rissue was fixed in $10 \%$ phosphate-buffered formalin ( $\mathrm{pH} 7.4$ ), and paraffin embedded. Five $\mu \mathrm{m}$ sections were cut at various levels and stained with hematoxylin-eosin, Elastic Van Gieson stain and Perls' iron stain. All specimens were re-examined independently by two pathologists (CAW, RJS), who were unaware of the diagnosis and hemodynamic data. Only the age of the patient was revealed. Pulmonary vascular lesions were described according to Wagenvoort and Mooi (2). Morphologic features such as medial hypertrophy, muscularization of arterioles, cellular intimal proliferation and concentric-laminar intimal fibrosis were scored semi-quantitatively with regard to severity and frequency $(0=$ absent, 1 = mild, 2 = moderate, 3 = severe), as described earlier (2). In evaluating the muscularity of the pulmonary arterial tree, the scores for medial hypertrophy and 
muscularization of arterioles were adjusted to the age of the patient (14-16). Subsequently, a consensus session revealed the definite scores. For the overall degree of muscularity a single composite score, the total muscularity score (TMS, $0=$ normal, $1=$ mildly increased, 2 = moderately increased, 3 = severely increased), was obtained on the basis of the scores for medial hypertrophy and arteriolar muscularization. Dilatation lesions, fibrinoid necrosis and plexiform lesions were documented as present or absent. The presence of plexiform lesions, fibrinoid necrosis, dilatation lesions or concentriclaminar intimal fibrosis was considered as "advanced pulmonary plexogenic arteriopathy".

Hemodynamic data. Cardiac catheterization was performed in all patients under general anesthesia. Data on pulmonary and systemic arterial and venous pressures, pulmonary blood flow, shunt size and pulmonary and systemic vascular resistance were collected. Pulmonary vascular resistance was determined using pulmonary blood flow, calculated with the Fick principle using assumed oxygen consumption. Pulse pressure and the ratios of pulmonary-to-systemic pressure and pulmonary-to-systemic vascular resistance were calculated.

Follow up data. Outcome was assigned to short-term and mid-term outcome. Perioperative death associated with pulmonary hypertensive crises was studied as short-term outcome variable, where perioperative death was defined as death during or within 21 days after cardiac surgery. Acute pulmonary hypertensive crises were defined as events of progressive and profound pulmonary hypertension and/or systemic desaturation, in the absence of obstruction of the pulmonary artery, combined with a decreased systemic circulation. In patients who underwent a univentricular repair, perioperative death associated with pulmonary hypoperfusion was studied as outcome variable. The persistence of pulmonary hypertension after corrective surgery was studied as mid-term outcome variable. Persistent pulmonary hypertension was defined as a loud second heart sound at physical examination, electrocardiographic evidence of right ventricular hypertrophy and echocardiographic features suggestive for elevated pulmonary artery pressure, in the absence of residual cardiac lesions.

Statistical analysis. Patients in the autopsy and biopsy groups were analysed separately because the indications to obtain lung rissue were dissimilar in both groups. Hemodynamic data were correlated with histologic findings using Pearson's correlation coëfficiënt. Categorical data were compared by Fisher's exact test. Statistical comparisons of hemodynamic and histologic data berween groups of patients were made using the Student's $t$ test or Mann-Whitney $U$ test when distribution was not normal. In the biopsy group comparisons of data were made between patients with and without clinical features of pulmonary hypertension during follow up, using the same tests. A value of $p<0.05$ was considered significant. 
Table 1. - Anatomical Diagnosis.

n

VSD

CAVSD

TGA

Truncus arteriosus

ASD with/without PAPVC

TAPVC

Tricuspid atresia

Fall.ot:

Others
- isolated 6

- with leftsided obstructive lesions 5

- isolated 6

- complex 3

- complex 9

1

$-\frac{1}{3}$

- complex 3

ASD indicates atrial septal defect; cAVSD, complete atrioventricular septal defect; PAPVC, partial abnormal pulmonary venous connection; TAPVC, total abnormal pulmonary venous connection; TGA, transposition of the great arteries; VSD, ventricular septal defect; complex indicates with associated lesions; $n$, number of patients.

\section{RESULTS}

\section{General}

In the study period, 47 patients underwent histologic and hemodynamic evaluation of the pulmonary vasculature. The total study group consisted of 29 males and 18 females, with a variety of complex congenital heart diseases (table 1 ). The median age at the time of the lung biopsy was 6.5 months with a range from 1 day to 16.8 years. The age distribution and the distribution of histological features in relation to age are shown in Figure 1. One patient had two lung biopsies with cardiac catheterizations. Three biopsies were taken as an isolated procedure and 14 during cardiac surgery (biopsy group, $\mathrm{n}=17$ ). Thirty-one specimens were taken at autopsy (autopsy group, $\mathrm{n}=$ 31). For the whole group the median time period between collection of lung specimen and hemodynamic data was 1,0 month, ranging from 3 days - 24 months. In 4 patients this period exceeded 6 months. Baseline characteristics of the autopsy and biopsy groups are shown in table 2. Pulmonary hemodynamics of the total study population are summarized in table 3.

Autopsy group. In the autopsy group, 26 of 31 patients had undergone cardiac surgery. In 9 out of the 21 patients who had undergone a biventricular repair, perioperative death was associated with pulmonary hypertensive crises. Preoperative hemodynamic parameters of these 9 patients did not differ significantly with those from patients who died perioperatively without pulmonary hypertensive crises $(n=4)$ or patients who died after the perioperative period $(n=8)$. Of the 5 patients who had a 
number of patients

\begin{tabular}{|c|c|c|c|c|c|c|}
\hline $\mathrm{MH}$ & 8 & 15 & 2 & 4 & 1 & 3 \\
\hline MA & 7 & 15 & 2 & 4 & 1 & 4 \\
\hline ICP & 0 & 3 & 0 & 0 & 0 & 2 \\
\hline cuIf & 0 & 2 & 0 & 0 & 1 & 1 \\
\hline$\overline{D L}$ & 0 & 0 & 0 & 0 & 1 & 1 \\
\hline $\mathrm{FN}$ & 0 & 2 & 0 & 0 & 1 & 0 \\
\hline $\mathrm{PL}$ & 0 & 1 & 0 & 0 & 1 & 1 \\
\hline
\end{tabular}

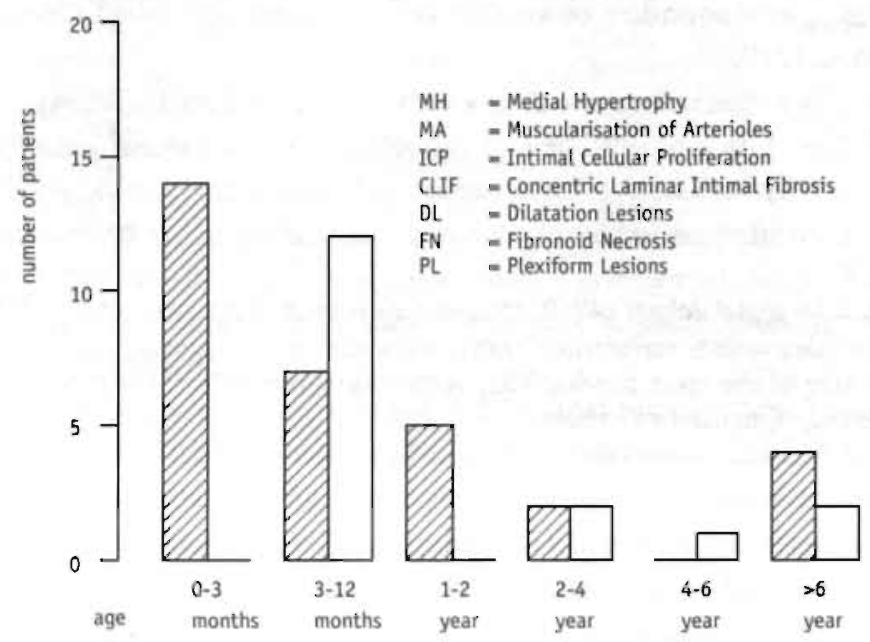

Figure 1. - Age distribution and the distribution of histological features in relation to age. //: Autopsy patients; 1 : Biopsy patients.

univentricular repair, 3 died perioperatively due to pulmonary hypoperfusion, whereas 2 died after the perioperative period. Preoperative hemodynamic data did not differ berween the former and the latter.

Biopsy group. In the biopsy group, 2 of the 17 patients died of causes not related to pulmonary vascular disease ( 1 infectious disease, 1 during a later surgical procedure) after 55 and 11 months respectively. The remaining 15 patients are still alive with a mean follow up of $69 \pm 39$ months (mean $\pm S D$ ), ranging from 14 months to 12.3 years. Five of these patients showed clinical fearures of persistent pulmonary hypertension in the absence of residual cardiac lesions.

Hemodynamic-histologic correlation. In the autopsy group, systolic, diastolic and mean pulmonary artery pressure, pulmonary pulse pressure and the pulmonary-tosystemic pressure ratio correlated significantly with the severity of medial hypertrophy $(r=0.55, r=0.46, r=0.51, r=0.60$ and $r=0.60$ respectively; all $p<0.05)$, arteriolar muscularization $(r=0.53, r=0.46, r=0.50, r=0.57$ and $r=0.56$ respectively; all $p<$ $0.05)$ and total muscularization score $(r=0.59, r=0.46, r=0.54, r=0.67$ and $r=0.64$ respectively; all $p<0.05)$. Pulmonary vascular resistance was correlated significantly 
Table 2. - Patient characteristics of the autopsy and biopsy groups.

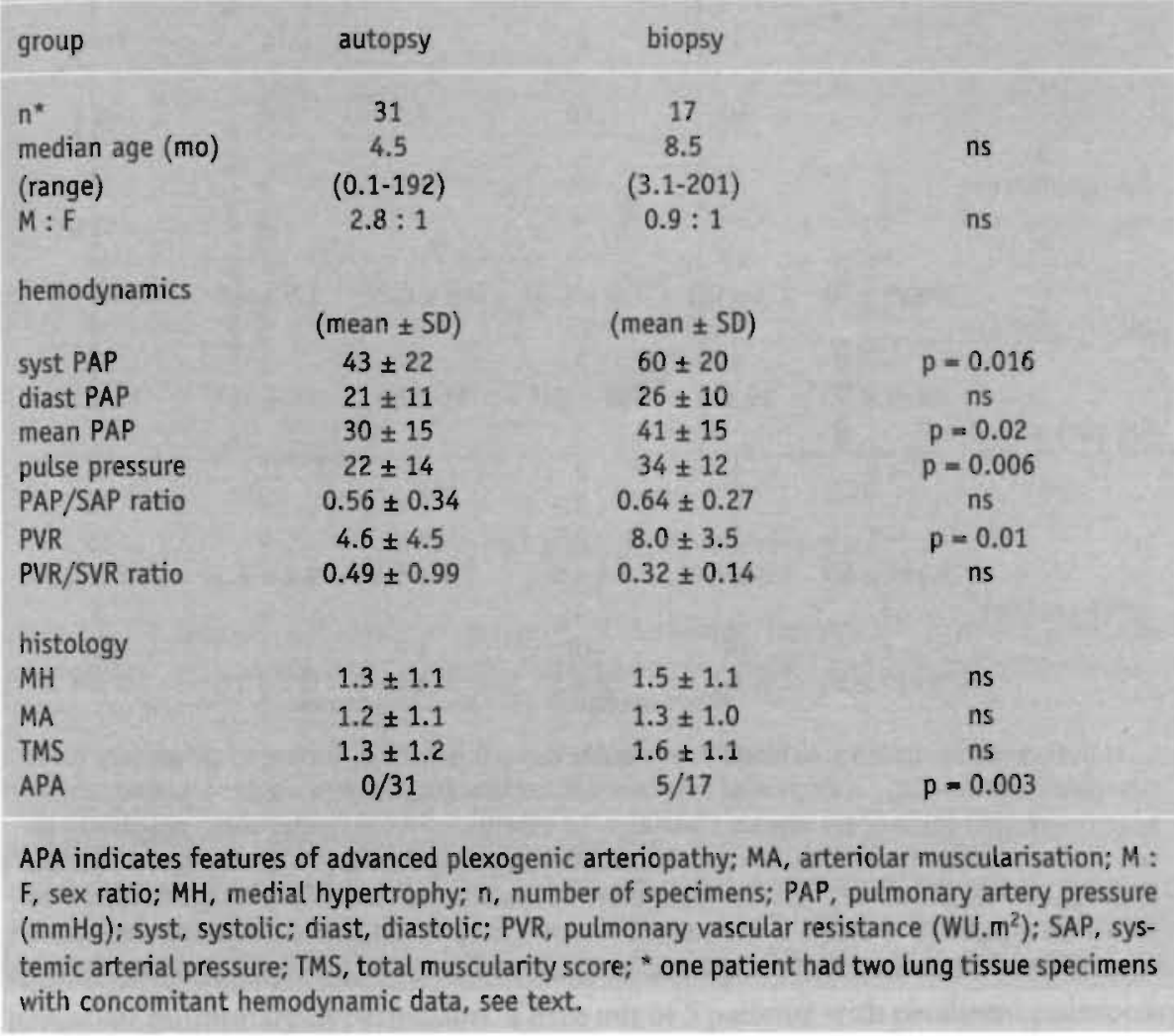

with medial hypertrophy only $(\mathrm{r}=0.39, \mathrm{p}<0.05)$. Pulmonary blood flow, shunt size, pulmonary-to-systemic resistance ratio and pulmonary venous pressures showed no correlation with the features of arterial muscularity.

In the biopsy group, none of the hemodynamic parameters significantly correlated with the features of arterial muscularization or the presence of cellular intimal. proliferation. Pulmonary artery pressures and pulmonary-to-systemic pressure ratio were significantly higher in patients with histologic lesions of "advanced plexogenic arteriopathy" compared to those without these features. This holds for the systolic pulmonary artery pressure $(75 \pm 18$ vs. $53 \pm 18 \mathrm{mmHg}, \mathrm{p}=0.03)$, the diastolic pulmonary artery pressure $(36 \pm 11$ vs. $21 \pm 5 \mathrm{mmHg}, \mathrm{p}=0.002)$, the mean pulmonary artery pressure $(53 \pm 14$ vs $36 \pm 12 \mathrm{mmHg}, \mathrm{p}=0.02)$, and the pulmonary-to-systemic pressure ratio $(0.94 \pm 0.19$ vs. $0.51 \pm 0.18, \mathrm{p}=0.01)$.

None out of 7 patients with pulmonary vascular resistance lower than 6WU.m² and none out of 9 patients with diastolic pulmonary artery pressure lower than $25 \mathrm{mmHg}$, cut-off values reported in earlier studies $(8,11,17)$ showed features of 
Table 3. - Pulmonary hemodynamic characteristics of the total study population.

\begin{tabular}{|c|c|c|c|c|c|c|}
\hline & & 1 & 2 & 3 & 4 & Total \\
\hline$n$ & & 10 & 28 & 4 & 6 & $48 \#$ \\
\hline \multirow[t]{4}{*}{ ap (shuntsize) } & $\hat{\imath}$ & - & 28 & - & 3 & 31 \\
\hline & $\downarrow$ & - & - & 4 & 1 & 5 \\
\hline & $=$ & 10 & - & - & 2 & 12 \\
\hline & mean $\pm S D$ & $1.1 \pm 0.1$ & $4.0 \pm 4.3^{*}$ & $0.6 \pm 0.2^{*}$ & $1.5 \pm 0.8$ & $2.8 \pm 3.6$ \\
\hline \multirow[t]{3}{*}{ mPAP $(\mathrm{mmHg})$} & $\uparrow$ & 5 & 25 & 2 & 5 & 37 \\
\hline & $=$ & 5 & 3 & 2 & 1 & 11 \\
\hline & mean $\pm S D$ & $19 \pm 6$ & $38 \pm 14^{\circ}$ & $31 \pm 22$ & $48 \pm 15^{*}$ & $35 \pm 16$ \\
\hline \multicolumn{7}{|l|}{ PVR (WU. $\left.\mathrm{m}^{2}\right)$} \\
\hline & $<4$ & 4 & 9 & - & 2 & 15 \\
\hline & $4-7$ & 4 & 8 & 2 & - & 14 \\
\hline & $>7$ & 1 & 9 & 1 & 4 & 15 \\
\hline & mean \pm SD & $3.9 \pm 2.6$ & $6.4 \pm 5.1$ & $8.1 \pm 5.8$ & $9.2 \pm 7.1$ & $6.3 \pm 5.1$ \\
\hline \multirow[t]{3}{*}{$\mathrm{mPVP}(\mathrm{mmHg})$} & $\uparrow$ & - & - & - & 6 & 6 \\
\hline & $=$ & 10 & 28 & 4 & - & 42 \\
\hline & mean $\pm S D$ & $8 \pm 3$ & $9 \pm 2$ & $6 \pm 1$ & $21 \pm 3^{*}$ & $9 \pm 5$ \\
\hline
\end{tabular}

1 , indicates normal pulmonary blood flow $(Q p / Q$ s ratio: $0.8-1.2) ; 2$, increased pulmonary blood flow (Qp/Qs ratio >1.2); 3, decreased pulmonary blood flow (Qp/Qs ratio $<0.8$ ); 4, pulmonary venous congestion (pulmonary venous pressure $>17 \mathrm{mmHg}$ ). $\mathrm{mPAP}$ indicates mean pulmonary artery pressure $(\uparrow>20 \mathrm{mmHg}) ; \mathrm{mPVP}$, mean pulmonary venous pressure $(\uparrow>17 \mathrm{mmHg}) ; n$, number of patients; PVR, puimenary vascular resistance; Qp, pulmonary blood flow; * significant difference with group I $(p<0.05)$. \# one patient had two lung tissue specimens with concomitant hemodynamic data, see text.

advanced plexogenic arteriopathy in the lung biopsy, while 5 out of 10 patients with pulmonary vascular resistance higher than $6 \mathrm{WU} \cdot \mathrm{m}^{2}$ and 5 out of 8 patients with a diastolic pulmonary artery pressure higher than $25 \mathrm{mmHg}$ did show these features $(\mathrm{p}=$ 0.04 and $p=0.009$ respectively, analysed for biopsy and autopsy groups together: $p=$ 0.003 and $p=0.002$ respectively; Figure 2).

Structure-function correlation with short-term outcome. Patients who died perioperatively associated with pulmonary hypertensive crises showed significantly increased medial hypertrophy, arteriolar muscularization and a higher muscularization score compared to those who died perioperatively without such crises (medial hypertrophy: $2.1 \pm 0.9$ vs. $0.5 \pm 1.0(p=0.01)$; arteriolar muscularization: $1.8 \pm 1.1$ vs. $0.5 \pm$ $1.0(p=0.04)$; muscularization score: $2.2 \pm 1.0$ vs. $0.5 \pm 1.0(p=0.01$, mean $\pm S D)$.

Structure-function correlation with mid-term outcome. Preoperative hemodynamic data from children with persistent pulmonary hypertension did not differ significantly from those without persistent pulmonary hypertension. This holds for the mean pulmonary artery pressure $(50 \pm 18 \mathrm{vs} .41 \pm 9 \mathrm{mmHg}, \mathrm{p}=0.22)$, the diastolic pulmonary artery pressure ( $32 \pm 15$ vs. $24 \pm 6 \mathrm{mmHg}, \mathrm{p}=0.38$ ), the pulmonary-to- 

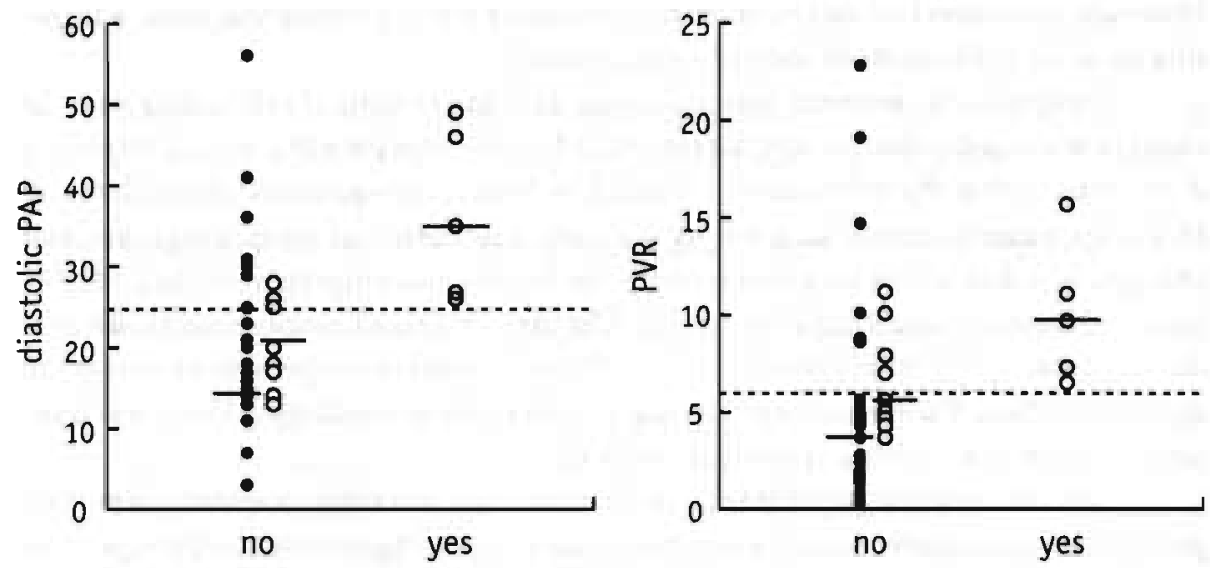

Advanced plexogenic arteriopathy

Figure 2. - Relation between the presence of histologic features of advanced plexogenic arteriopathy and diastolic PAP (pulmonary artery pressure, $\mathrm{mmHg}$ ) and PVR (pulmonary vascular resistance, WU. $\left.\mathrm{m}^{2}\right)$. O. Autopsy patients; 0: Biopsy patients.

systemic pressure ratio $(0.81 \pm 0.32$ vs. $0.58 \pm 0.15, \mathrm{p}=0.17)$, the pulmonary vascular resistance $\left(10.1 \pm 4.7\right.$ vs. $7.7 \pm 2.2$ WU. $\left.\mathrm{m}^{2}, \mathrm{p}=0.20\right)$, and the pulmonary-to-systemic resistance ratio $(0.31 \pm 0.18$ vs. $0.34 \pm 0.13, \mathrm{P}=0.82)$. Of the histological features studied, only the presence of plexiform lesions was significantly associated with signs of persistent pulmonary hypertension. Three out of 5 patients with persistent pulmonary hypertension showed plexiform lesions, which indicates that the presence of plexiform lesions has a high positive predictive value $(p=0.02$, positive predictive value $100 \%)$ for persistent pulmonary hypertension, but is rather insensitive. The histological classification "features of advanced plexogenic arteriopathy" did not correlate significantly with signs of persistent pulmonary hypertension at follow up $(\mathrm{p}=0.26$, positive predictive value $60 \%$ ).

\section{DISCUSSION}

The present study demonstrates merely limited correlations between hemodynamic and histologic assessment of the pulmonary vascular bed in a highly selected group of children with complex congenital heart disease. Both techniques appeared of limited value in predicting persistent pulmonary hypertension after corrective surgery at midterm follow up. Only plexiform lesions in the lung biopsy were predictive, although rather insensitive, for persisting pulmonary hypertension. Patients with features of advanced plexogenic arteriopathy had significantly higher pulmonary artery pressures. 
However, the individual variation of the pulmonary artery pressure was wide, hampering accurate predictions in the individual patient.

Discrepancies between hemodynamic data and structural pulmonary vascular changes in the individual patient, as frequently found in our patients, are not surprising if one realizes that the information obtained by both techniques is far from identical. Histologic examination of lung biopsy is a static description of morphologic vascular changes, which does not take into account the functional component of the endothelium and smooth muscle cells $(16,18,19)$. On the other hand, hemodynamic data are derived data, which reflect merely indirect the functional consequences of changes in the vascular bed. Various assumptions have to be made in calculating flows and resistances, which may result in potential errors (3).

It is believed that patients with early, potentially reversible, stages of pulmonary plexogenic arterioparhy may develop pulmonary hypertensive crises in perioperative periods (7). In this study, we have indeed shown that increased muscularity of the pulmonary tree, expressed as medial hypertrophy, muscularization of arterioles or the combined total muscularity score, was associated significantly with perioperative pulmonary hypertensive crises. Preoperative hemodynamic data, however, did not allow the prediction of perioperative mortality associated with pulmonary hypertensive crises. Although treatment results have improved with the introduction of vasodilators like epoprostenol and, more recently, inhaled nitric oxide, these life-threatening events continue to lead to significant perioperative mortality.

Assessment of an increased muscularity of the pulmonary tree in an open lung biopsy can therefore help to identify children at risk for the development of a perioperative pulmonary hypertensive crises. Moreover, the presence of plexiform lesions in an open lung biopsy was $100 \%$ predictive for persistent pulmonary hypertension after corrective surgery.

A limitation of the present study is that lung biopsies were not performed routinely, but in patients judged to be at risk for pulmonary vascular disease. Thirty-one samples were obtained at autopsy. As a result, the patients in this study represent a highly selected group with a variety of complex cardiac anomalies. Cases were not classified on the basis of anatomical diagnosis because mechanical forces, acting on the pulmonary vasculature and resulting from abnormal pulmonary hemodynamics caused by the anomaly, rather than the anatomical diagnosis itself, are responsible for the initiation of this specific vascular disease process in children with congenital heart disease.

We conclude that, preoperative hemodynamic data in children with congenital heart disease are of limited predictive value for perioperative pulmonary hypertensive crises and for persistent pulmonary hypertension after corrective surgery. Increased muscularity of the pulmonary arterial tree is associated with perioperative pulmonary hypertensive crises and plexiform lesions are $100 \%$ predictive for persistent pulmonary hypertension after corrective surgery. 


\section{REFERENCES}

1. Wagenvoort CA. Open lung biopsies in congenital heart disease for evaluation of pulmonary vascular disease. Predictive value with regard to corrective operability. Histopathology 1985;9:417-436.

2. Wagenvoort CA, Mooi WJ. Biopsy pathology of the pulmonary vasculature. London: Chapman and Hall, 1989.

3. Hoffman JI. Diagnosis and treatment of pulmonary vascular disease. Birth Defects 1972;8:9-18.

4. Hoffman JI, Rudolph AM, Heymann MA. Pulmonary vascular disease with congenital heart lesions: pathologic features and causes. Circulation 1981;64:873-877.

5. Heath D, Edwards J. The pathology of hypertensive pulmonary vascular disease. A description of six grades of structural changes in the pulmonary arteries with special reference to congenital cardiac septal defects. Circulation 1958;18:533-547.

6. Rabinovitch M, Haworth SG, Castaneda AR, Nadas AS, Reid LM. Lung biopsy in congenital heart disease: a morphometric approach to pulmonary vascular disease. Circulation 1978;58:1107-1122.

7. Haworth SG, Radley-Smith R, Yacoub M. Lung biopsy findings in transposition of the great arteries with ventricular septal defect: potentially reversible pulmonary vascular disease is not always synonymous with operability. J. Am. Coll. Cardiol. 1987;9: 327-333.

8. Haworth SG. Pulmonary vascular bed in children with complete atrioventricular sepral defect: Relation between structural and hemodynamic abnormalities. Am. J. Cardiol. 1986;57:833-839.

9. Frescura C, Thiene G, Franceschini E, Talenti E, Mazzucco A. Pulmonary vascular disease in infants with complete atrioventricular septal defect. Int. J. Cardiol. 1987;15:91-103.

10. Haworth SG. Pulmonary vascular disease in ventricular septal defect: Structural and functional correlations in lung biopsies from 85 patients, with outcome of intracardiac repair. J. Pathol. 1987;152:157-168.

11. Bush A, Busst CM, Haworth SG, Hislop AA, Knight WB, Corrin B, Shinebourne EA. Correlations of lung morphology, pulmonary vascular resistance, and outcome in chit dren with congenital heart disease. Br. Heart J. 1988;59:480-485.

12. Rabinovitch M, Keane JF, Norwood WI, Castaneda AR, Reid L. Vascular structure in lung tissue obtained at biopsy correlated with pulmonary hemodynamic findings after repair of congenital heart defects. Circulation 1984;69:655-667.

13. Braunlin EA, Moller JH, Parton C, Lucas RV Jr, Lillehei CW, Edwards JE. Predictive value of lung biopsy in ventricular septal defect: long-term follow-up. J. Am. Coll. Cardiol 1986;8:1113-1118.

14. Reid L. The pulmonary circulation: remodeling in growth and disease. Am. Rev. Respir. Dis. 1979;119:531-546. 
15. Haworth SG, HislopAA. Pulmonary vascular development: normal values of peripheral vascular structure. Am. J. Cardiol. 1983;52:578-583.

16. Reid L. Structure and function in pulmonary hypertension. New perceptions. Chest 1986;89:279-288.

17. Wilson NJ, Seear MD, Taylor GP, LeBlanc JG, Sandor GG. The clinical value and risks of lung biopsy in children with congenital heart disease. J. Thorac. Cardiovasc. Surg. 1990;99:460-468.

18. Haworth SG. Understanding pulmonary vascular disease in young children. Int. J. Cardiol. 1987;15:101-103.

19. Haworth SG. Pathophysiological and metabolic manifestations of pulmonary vascular disease in children. Herz 1992;17:254-261. 
CHAPTER 3

Pulmonary artery remodeling differs in hypoxia- and monocrotaline-induced pulmonary hypertension 


\section{SUMMARY}

In the present study we analyzed structural characteristics of muscular pulmonary arteries and arterioles in two classic models of pulmonary hypertension, the rat hypoxia and monocrotaline models. We hypothesized that an increase in medial cross-sectional area would result in reduction of the lumen area and that these parameters would correlate with the increase in pulmonary artery pressure (PAP). Four weeks after a single injection of monocrotaline (MCT) or after four weeks of hypoxic exposure the rats were killed. Both MCT and chronic hypoxia induced right ventricular hypertrophy. In separate groups of rats both MCT and chronic hypoxia increased PAP. MCT increased the media crosssectional area of pulmonary arteries with an external diameter between 30-100 $\mu \mathrm{m}$ and 101-200 $\mu \mathrm{m}$ and reduced the lumen area of pulmonary arteries with an external diameter between 101-200 $\mu \mathrm{m}$. Chronic hypoxia only slightly increased the media cross-sectional area without a change of the lumen area. Both MCT and hypoxia increased the percentage of partly muscularized and muscularized arterioles. The angiotensin converting enzyme (ACE) inhibitor captopril $(0.5 \mathrm{mg} / \mathrm{kg} / \mathrm{hr})$ had no effect on MCT-induced pulmonary hypertension, right ventricular hypertrophy and pulmonary artery remodeling. In chronic hypoxic rats it prevented an increase in medial cross-sectional area of pulmonary arteries with an external diameter between $30-100 \mu \mathrm{m}$ and attenuated the increase in the percentage of muscularized arterioles, without any effect on the PAP.

We conclude that MCT, in contrast to chronic hypoxia, induces structural changes of muscular pulmonary arteries with an external diameter between 101-200 $\mu \mathrm{m}$ which may contribute to an increased PAP and right ventricular hypertrophy. These data also suggest that angiotensin II plays a pivotal role in remodeling of pulmonary arteries in hypoxia but not in MCT-induced pulmonary hypertension. 


\section{INTRODUCTION}

Pulmonary hypertension is a common complication of cardio-pulmonary diseases. Regardless of the etiology, all patients with chronic pulmonary hypertension have structural pulmonary vascular changes, right ventricular hypertrophy and, in the long term, right ventricular failure (1-3). In patients with congenital heart disease, however, preoperative hemodynamic findings and postoperative clinical outcome do not always correlate with structural pulmonary artery changes (4-8). This discrepancy between hemodynamics and pulmonary artery structure is also true for animal studies. For example, the angiotensin converting enzyme (ACE) inhibitor cilazapril completely prevented the thickening of the media of pulmonary arteries in chronic hypoxic rats but did not decrease the pulmonary artery pressure (PAP) or right ventricular weight (9). The apparent discrepancies between changes in pulmonary vascular structure and hemodynamic function may be explained by the fact that vasoconstriction, rather than structural narrowing of pulmonary arteries, plays a pivotal role in the rise of the PAP. An alternative explanation is that previous studies have focused on the wrong parameters of structural pulmonary vascular changes. In most studies medial wall thickness is expressed as a percentage of the arterial external diameter (10-12). This parameter, however, does not adequately reflect changes in medial cross-sectional area and lumen area since the external diameter of arteries may also change during the complex process of vascular remodeling (13). Recently, Mulvany and co-workers introduced an adaptation of terminology to allow a precise description of the structural changes that can occur in the vasculature (13). The media to lumen ratio and the lumen area, rather than medial wall thickness, are essential parameters in this analysis. In contrast to the systemic circulation, description of structural vascular changes according to the concept of Mulvany (14-19) has not yet been employed in the pulmonary circulation. We therefore determined the lumen area, the medial cross-sectional area and the ratio of media to lumen area of muscular pulmonary arteries with an external diameter between 30-100 and 101-200 $\mu \mathrm{m}$ in two classic rat models of pulmonary hypertension, the rat hypoxia- and monocrotaline models $(11,20,21)$. To optimize structural analyses, the pulmonary vessels were fixed under standard intravascular pressure and maximal vasodilatation. Right ventricular weight and PAP were measured to correlate structural pulmonary vascular changes with hemodynamic function. Moreover, we investigated the effects of the ACE inhibitor captopril on pulmonary vascular remodeling and pulmonary hemodynamics, because angiotensin II (AII) is believed to be involved in hypoxia and MCT-induced pulmonary hypertension. In both the systemic and pulmonary circulation AII acts as a vasoconstrictor and can induce structural arterial changes like smooth muscle hypertrophy and proliferation as well as matrix protein synthesis (22-26). In animal models of pulmonary hypertension, several ACE inhibitors are known to prevent or attenuate the development of pulmonary hypertension and medial thickening of pulmonary arteries $(9,27-32)$. 
The consequences of this intervention for the lumen area of pulmonary arteries have, however, not been described.

Thus we hypothesized that both chronic hypoxia and monocrotaline would increase the medial cross-sectional area and decrease the lumen area of muscular pulmonary arteries. Second, we hypothesized that changes in the media to lumen ratio and lumen area of muscular pulmonary arteries would correlate with changes in PAP. Finally we hypothesized that captopril would prevent or attenuate the reduction of the lumen area of the pulmonary arteries, right ventricular hypertrophy, and the increase in PAP in these two rat models.

\section{METHODS}

\section{Morphological Studies}

Forty young male Wistar rats (Iffa Credo, Someren, The Netherlands) were used. Body weight was $145-200 \mathrm{~g}$ at the start of the experiments. The rats were randomly assigned to one of four treatment groups. Food (RMH-TM, Hope Farms, Woerden, The Netherlands) and water were freely available to all groups of animals. The experiments were performed according to instirutional guidelines for the use and care of animals. All rats were killed four weeks after the start of the experiment.

Group 1: $n=8$, Monocrotaline (MCT)

At day one these rats received a single subcutaneous injection of monocrotaline $(300 \mu \mathrm{l}, 60 \mathrm{mg} / \mathrm{kg}$ in $0.2 \mathrm{~N} \mathrm{HCl}$, Sigma, St Louis, MO).

\section{Group 2: $n=8$, Hypoxia $(H)$}

At day one these rats were placed into a normobaric chamber for four weeks. Hypoxic exposure was accomplished by ventilation with room air $(2.5 \mathrm{~L} / \mathrm{min})$ and $\mathrm{N}_{2}$ $(2.5 \mathrm{~L} / \mathrm{min})$ resulting in a constant $\mathrm{O}_{2}$ concentration of $10 \%$. The $\mathrm{O}_{2}$ concentration was checked every day using an $\mathrm{O}_{2}$ analyzer (AVL 993, AVL LIST GmbH, Graz, Austria). Each day the chamber was opened for approximately 2 minutes to replenish food and water.

\section{Group 3: $n=8$, Monocrotaline and captopril (MCTcap)}

At day one these rats received a single subcutaneous injection of monocrotaline $(300 \mu \mathrm{l}, 60 \mathrm{mg} / \mathrm{kg}$ in $0.2 \mathrm{~N} \mathrm{HCl})$. The ACE-inhibitor captopril $(0.5 \mathrm{mg} / \mathrm{kg} / \mathrm{hr}$ in $0.9 \% \mathrm{NaCl}$, Sigma) was given for four weeks via osmotic minipumps (Alzet model 2002, Alza Corp., Palo Alto, $\mathrm{Ca}$ ) implanted subcutaneously between the shoulder blades under ether anesthesia. Before implantation the minipumps were placed in $0.9 \%$ $\mathrm{NaCl}$ at $37^{\circ} \mathrm{C}$ for four hours. After 14 days the minipumps were replaced and a new pump filled with captopril was inserted at the same site. 
Group 4: $n=8$, Hypoxia and captopril (Hcap)

These rats were kept under hypoxic conditions for four weeks as described for group 2. During this period the rats received captopril in the same way as described for group 3.

Group 5: $n=8$, Control rats (C)

These rats were kept under normoxic conditions (room air) without intervention.

Preparation of lung tissue for morphological measurements

After induction of anesthesia with sodium pentobarbital $(60 \mathrm{mg} / \mathrm{kg}$ intraperitoneally), the right jugular vein was cannulated and the tip of the Silastic canula was positioned into the right atrium. After opening the abdominal wall and the thoracic caviry a clamp was placed on the inferior caval vein. The abdominal aorta was cut open to allow maximal perfusion of the lung vessels. A solution containing phosphate buffered saline (PBS, pH 7.4) and nitroprusside ( $1 \mathrm{mg} / \mathrm{ml}$, Sigma) was perfused at a pressure of $18 \mathrm{~mm} \mathrm{Hg}$ for ten minutes through the pulmonary vessels via the canula in the right atrium. Subsequently, a solution of $10 \%$ phosphate buffered formalin $(\mathrm{pH} 7.4)$ and nitroprusside $(1 \mathrm{mg} / \mathrm{ml})$ was infused for ten minutes for perfusion fixation under maximal vasodilatation. At the same time $10 \%$ phosphate buffered formalin ( $\mathrm{pH} 7.4)$ was administered into the lungs via a trachea tube, at a pressure of $20 \mathrm{~cm} \mathrm{H} \mathrm{H}_{2} \mathrm{O}$. Subsequently, heart and lungs were removed and fixed overnight in $10 \%$ phosphate buffered formalin ( $\mathrm{pH} 7.4$ ). Both left and right lung were processed for light microscopy. The lungs were paraffin embedded and $4 \mu \mathrm{m}$ sections were stained with Lawson's stain (Klinipath, Zevenaar, The Netherlands).

\section{Assessment of right ventricular hypertrophy}

Both atria, the pulmonary trunk, and the aorta were removed from the heart. The right ventricular wall was separated from the left ventricular wall and ventricular septum. Wet weight of the right ventricle, free left ventricular wall and ventricular septum was determined. Right ventricular hypertrophy was expressed as the ratio of weight of the right ventricular wall (RV) and that of the free left ventricular wall and ventricular septum $(L V+S)$.

\section{Hematocrit}

The hematocrit was determined using a micro capillary centrifuge for five minutes. After induction of anesthesia with pentobarbital blood samples were drawn from the orbita. 


\section{Light microscopic analysis of pulmonary arteries}

\section{Remodeling of pulmonary arteries}

Slides were analyzed by light microscopy by one observer (RJvS) who was unaware of the treatment group. To assess the type of remodeling of muscular pulmonary arteries, microscopic images were analyzed using a computerized morphometric system (Quantimer 570, Leica, Cambridge, U.K.). Total vessel area was defined as the area within the lamina elastica externa and lumen area was defined as the area within the lamina elastica interna. Medial area is the area between the lamina elastica interna and the lamina elastica externa. Arteries were categorized depending on the external diameter. Category I included arteries with an external diameter between 30 and 100 $\mu \mathrm{m}$, and category II included arteries with an external diameter between 101 and 200 $\mu \mathrm{m}$. Within each category ten arteries were measured per animal. The average of 10 values obtained were used for calculations.

\section{Assessment of muscularization of arterioles}

Extension of smooth muscle cells into usually nonmuscular arterioles of the alveolar wall and alveolar duct was assessed as follows. At $\times 400$ magnification 100 alveolar wall and alveolar duct vessels were counted and noted as muscular, partially muscular, or nonmuscular. These alveolar wall and alveolar duct vessels included small venules which could not be distinguished from normal pulmonary arterioles. A completely muscular arteriole was defined as an arteriole with a double elastic lamina for more than half of its circumference. An arteriole was categorized as partially muscular if the double elastic lamina was less than half of its circumference. A normal nonmuscular arteriole had a single elastic lamina. Intra observer variation was $10 \%$.

\section{Hemodynamic Studies}

For hemodynamic measurements, separate groups of male Wistar rats (mean initial body weight $178 \mathrm{gr}$ ) were used and treated in an identical way as the rats used for structural pulmonary vascular analysis (MCT $n=6$, MCTcap $n=7, H n=7$, Hcap $\mathrm{n}=7, \mathrm{C}, \mathrm{n}=6$ ).

PAP was measured using the technique described by Rabinovitch and coworkers (33). In brief, the animals were anesthetized $(60 \mathrm{mg} / \mathrm{kg}$ pentobarbital, intraperitoneally) and placed on a heated table $\left(37^{\circ} \mathrm{C}\right)$. The trachea was intubated and the animals were respirated with room air at 60 strokes $/ \mathrm{min}$. and $2.5 \mathrm{ml}$ tidal volume. The right jugular vein was isolated and a stainless steel introducer and catheter were passed via a small transverse cut. The catheter was connected to a pressure monitor and was advanced into the right ventricle and pulmonary trunk under guidance of the pressure tracing. With the catheter in place, the introducer was carefully retracted. Following stabilization during 15 minutes, PAP was recorded during a 15-minute period using a miniature pressure transducer (CP-01; Century Technology, Ingle- 
wood, CA) and a computerized data-acquisition system (HDAS; Instruments Service's Dept., UM, Maastricht, The Netherlands). Mean pulmonary artery pressure was calculated by digital integration.

\section{Statistical analysis}

Data are expressed as means \pm SD. Statistical significance was defined at $p<0.05$. Intergroup differences were evaluared with a non-parametric Mann-Whitney $U$ test with a Bonferroni correction for multiple group comparison (34).

\section{RESULTS}

\section{Morphological Studies}

\section{Body and cardiac weights}

Rats in the control group gained $124 \pm 24 \mathrm{~g}$ during four weeks. Rats exposed to hypoxia or treated with MCT only gained half the weight compared to the control group. In the MCT group, captopril had no significant influence on the body weight change (Table 1). In the hypoxic group captopril treatment diminished the gain in body weight further. The MCT and hypoxic groups exhibited significant right ventricular hypertrophy, defined as an increase of the ratio of right ventricular weight and the sum of the weight of the left ventricular free wall and interventricular seprum $(\mathrm{RV} / \mathrm{LV}+\mathrm{S}$ ratio) $(\mathrm{MCT}=0.69 \pm 0.16, \mathrm{H}=0.51 \pm 0.09, \mathrm{C}=0.22 \pm 0.03$, both $\mathrm{p}<$ $0.001)$ compared with the control group. In both groups captopril treatment had no significant effect on the $\mathrm{RV} / \mathrm{LV}+\mathrm{S}$ ratio. Hematocrit values significantly increased in the hypoxic rats $(H=72 \pm 6, C=47 \pm 2, p<0.001)$, whereas the hematocrit significantly decreased in the MCT-treated rats (MCT $=42 \pm 4, C=47 \pm 2, p<0.05)$. Captopril treatment had no effect on the hematocrit (Table 1).

\section{Vessel dimensions}

\section{Category I arteries (external diameter 30-100 $\mu \mathrm{m}$ )}

MCT significantly increased the media to lumen ratio (MCT $=46 \pm 9, \mathrm{C}=24 \pm 4, \mathrm{p}<$ 0.001 ) and the medial cross-sectional area $(\mathrm{MCT}=1,435 \pm 344, \mathrm{C}=961 \pm 387, \mathrm{p}<$ 0.05 ) of category I pulmonary arteries. The lumen area showed a trend to decrease although this does not reach significant levels $(\mathrm{p}=0.2)$ (Table 2 and Figure $1 \mathrm{~A}$ and $1 \mathrm{~B})$. Hypoxia also increased the media to lumen ratio $(\mathrm{H}=38 \pm 13, \mathrm{C}=24 \pm 4, \mathrm{p}=0.02)$. The medial cross-sectional area showed a trend to increase $(\mathrm{H}=1,326 \pm 410, \mathrm{C}=961$ $\pm 387, \mathrm{p}=0.07$ ) whereas the lumen area was not changed. In MCT-rreated rats captopril did not effect the media to lumen ratio nor the lumen area. In the hypoxic rats captopril prevented an increase in the media to lumen ratio (Hcap $=28 \pm 17, \mathrm{H}=38 \pm$ 


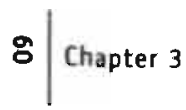

Table 1. - Body weight, heart weight and hematocrit of the five experimental groups.

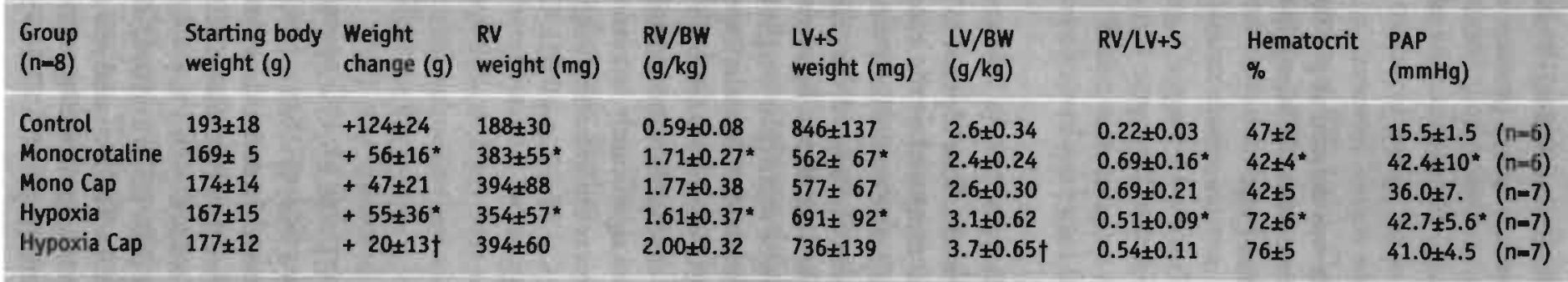

All values are means $\pm S D ; n$, number of animals per group; $R V$, right ventricular weight; $B W$, body weight; $L V$, left ventricular weight; $L V+S$, left ventricular weight plus septal weight; PAP, pulmonary artery pressure (data from separate groups of rats). ${ }^{*} p<0.05$ compared with control group. $\dagger p<0.05$ compared with hypoxia. 

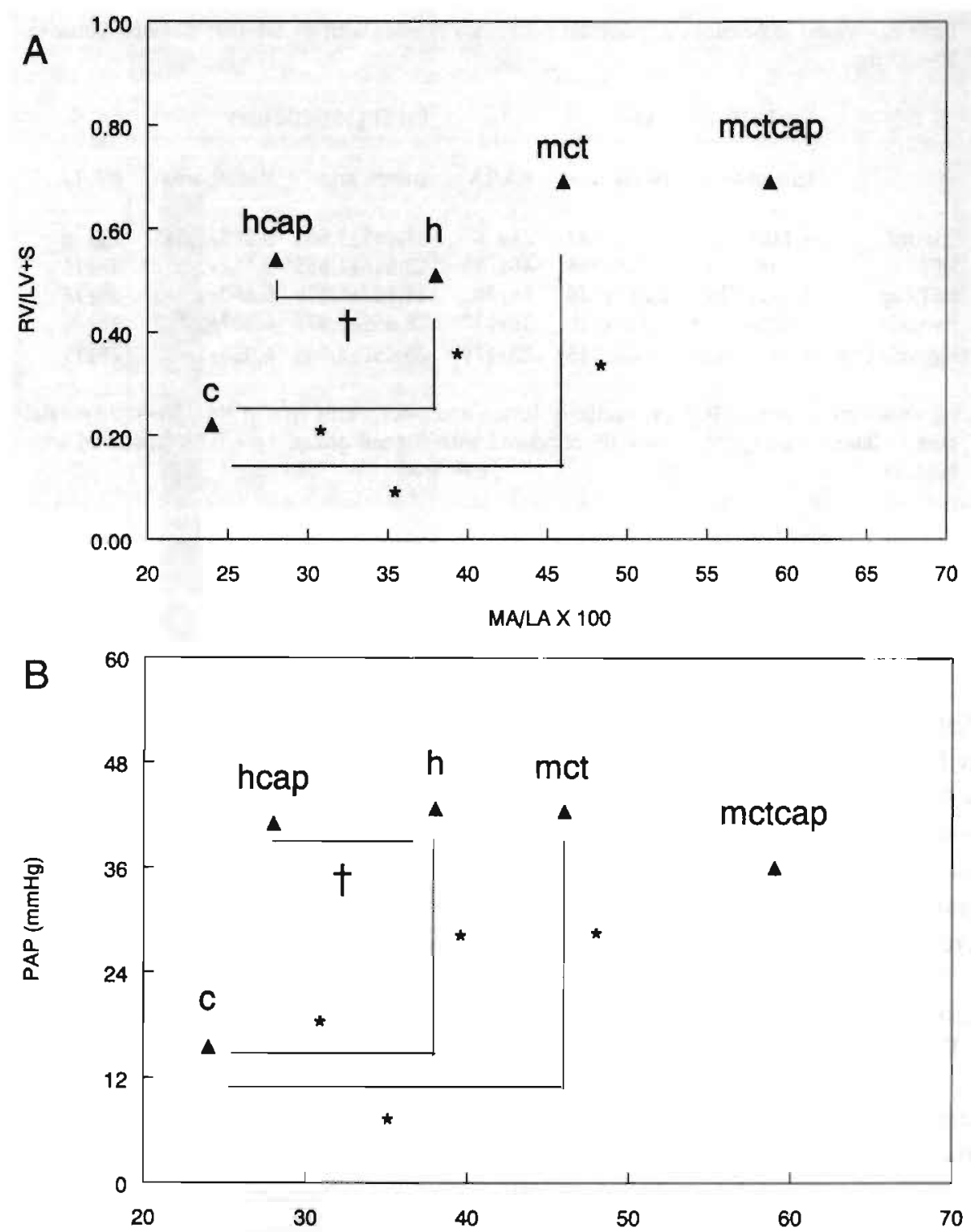

MAILA X 100

Figure $1 \mathrm{~A}$ and B. - Media to lumen ratio (MA/LA) of category I pulmonary arteries in relation to (1A) the ratio of weight of the right ventricular wall and that of the free left ventricular wall and ventricular septum (RV/LV+S) and (1B) pulmonary artery pressure (PAP) in control rats (C), monocrotaline treated rats (MCT), monocrotaline and captopril treated rats (MCTcap), chronic hypoxic rats $(H)$ and chronic hypoxic and captopril treated rats (Hcap). All values are presented as means. For standard deviations see Tables 1 and $2 .{ }^{*} p<0.05$ vs control. $\uparrow p<0.05$ vs hypoxia. 


\begin{tabular}{|c|c|c|c|c|c|c|}
\hline & \multicolumn{3}{|c|}{ Cat I $(30-100 \mu \mathrm{m})$} & \multicolumn{3}{|c|}{ Cat II $(101-200 \mu \mathrm{m})$} \\
\hline & Lumen area & Medial area & MA/LA & Lumen area & Medial area & $M A / L A$ \\
\hline Control & $4,146 \pm 1,466$ & $961 \pm 387$ & $24 \pm 4$ & $17,463 \pm 3,601$ & $3,826 \pm 1,545$ & $21 \pm 6$ \\
\hline $\mathrm{MCT}$ & $3,292 \pm 383$ & $1,435 \pm 344^{\star}$ & $46 \pm 9^{*}$ & $13,514 \pm 1,555^{*}$ & $5,112 \pm 1,502^{\prime}$ & $38 \pm 10^{*}$ \\
\hline МСТ Сар & $3,225 \pm 899$ & $1,451 \pm 326$ & $59 \pm 28$ & $16,192 \pm 4,119$ & $5,890 \pm 1,743$ & $39 \pm 18$ \\
\hline Hypoxia & $4,020 \pm 1,218$ & $1,326 \pm 410$ & $38 \pm 13^{*}$ & $18,855 \pm 3,977$ & $4,807 \pm 1,167$ & $26 \pm 6$ \\
\hline Hypoxia Cap & $4,180 \pm 528$ & $944 \pm 115 t$ & $28 \pm 17 \dagger$ & $20,452 \pm 3,045$ & $4,932 \pm 1,407$ & $29 \pm 19$ \\
\hline
\end{tabular}

13, $\mathrm{p}<0.05)$ and medial cross-sectional area (Hcap $=944 \pm 115, \mathrm{H}=1,326 \pm 410, \mathrm{p}<$ $0.05)$. Captopril had no effect on the lumen area.

Category II arteries (external diameter 101-200 $\mu \mathrm{m}$ )

MCT significantly increased the media to lumen ratio (MCT $=38 \pm 10, C=21 \pm 6, p$ $<0.05)$ and medial cross-sectional area $(\mathrm{MCT}=5,112 \pm 1,502, \mathrm{C}=3,826 \pm 1,545, \mathrm{p}$ $<0.05$ ) of category II pulmonary arteries whereas the lumen area decreased compared to control rats $(\mathrm{MCT}=13,514 \pm 1,555, \mathrm{C}=17,463 \pm 3,601, \mathrm{p}<0.05)$. Hypoxia did not affect the media to lumen ratio or the lumen area, whereas the medial cross-sectional area increased to some extent $(H=4,807 \pm 1,167, C=3,826 \pm 1,545$, $\mathrm{P}$ $=0.07$ ). Captopril treatment had no effect on the media to lumen ratio, medial cross-secrional area and lumen area neither in MCT-treated rats nor in hypoxic rats (Table 2).

\section{Arterioles}

Both MCT and hypoxia increased the percentage of pardy muscularized and muscularized arterioles and decreased the percentage of nonmuscularized arterioles (Figure 2). In the MCT-treated rats captopril had no effect on muscularization of arterioles, whereas in hypoxic rats it reduced the percentage of muscularized arterioles and signifcantly increased the percentage of partly-muscularized and nonmuscularized arterioles.

Hemodynamic Studies

MCT and chronic hypoxia induced a significant increase in PAP (MCT $=42.4 \pm 10$ $\mathrm{mmHg}, \mathrm{H}=42.7 \pm 5.6 \mathrm{mmHg}, \mathrm{C}=15.5 \pm 1.5 \mathrm{mmHg}, \mathrm{p}<0.005$, Table 1). In both 


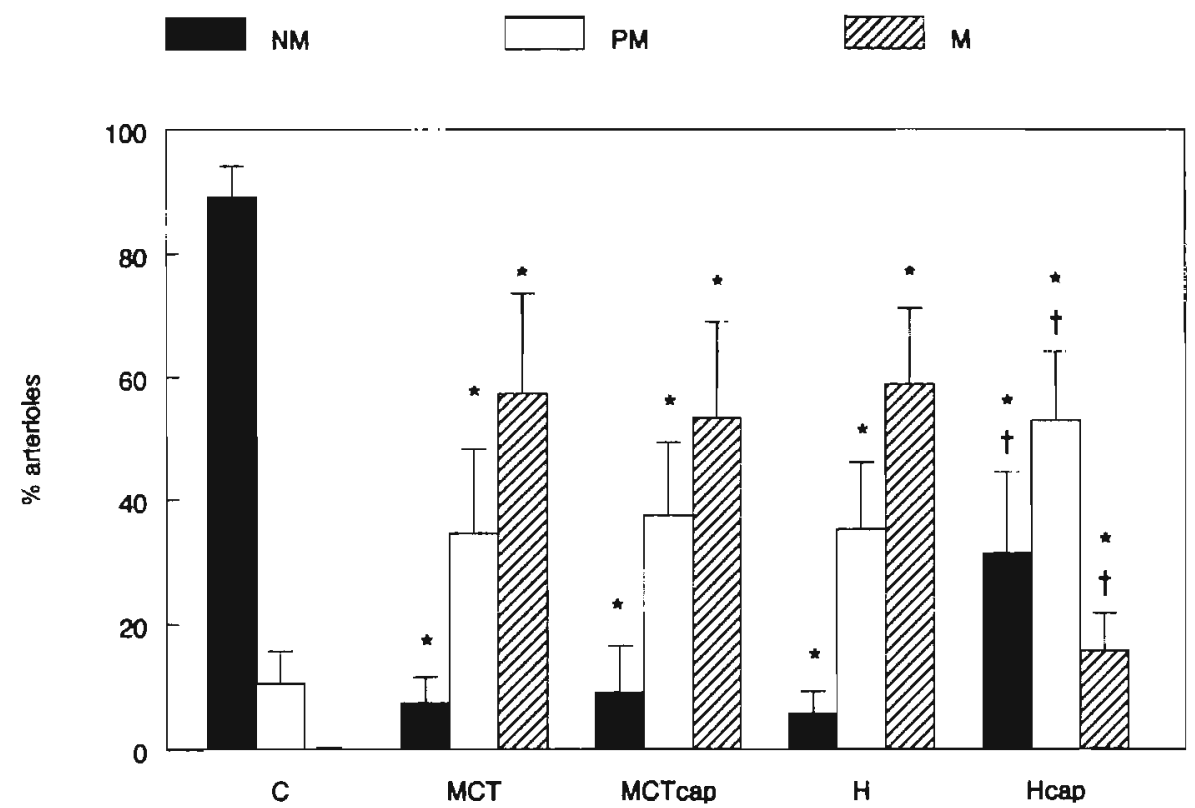

Figure 2. - The percentage of nonmuscular (NM), partially muscular (PM) and muscular (M) arterioles in control rats (C), monocrotaline treated rats (MCT), monocrotaline and captopril treated rats (MCTCap), chronic hypoxic rats $(\mathrm{H})$ and chronic hypoxic and captopril treated rats (Hcap). All values are presented as means \pm SD. ${ }^{*} p<0.05$ vs control. $\dagger p<0.05$ vs hypoxia.

groups captopril did not affect PAP. Captopril treatment had no significant effect on the PAP in control rats (data not shown).

\section{DISCUSSION}

This is one of the first morphometrical studies of muscular pulmonary arteries, analyzed under standard intravascular pressure and maximal vasodilatation, in which changes of pulmonary artery structure and changes in pulmonary artery pressure are compared.

Although the increases in PAP and right ventricular hypertrophy were compa rable in the rat hypoxia and MCT model, structural analysis of muscular pulmonary arteries reveals major differences between the two models which may be due to the way we analyzed the pulmonary vascular structure. In general, structural pulmonary vascular changes in animal models of chronic pulmonary hypertension include thickening of the media of muscular pulmonary arteries and muscularization of normally nonmuscular arterioles. Some studies have shown that chronic hypoxia and MCT 
induce different patterns of pulmonary vascular remodeling. Muscularization of arterioles is seen in both models, however, medial hypertrophy of muscular pulmonary arteries is more extensive in monocrotaline treated rats $(35,36)$. Only a few studies report the consequences of these structural vascular changes for the lumen diameter $(11,20,37)$. These investigators stated that thickening of the wall of pulmonary arteries contribured to a decrease in the lumen diameter. Changes in lumen diameter, however, were based on arteriograms and were investigated withour maximal vasodilatation. Thus vasoconstriction rather than structural vascular changes may have been responsible for the reported reduction of the lumen diameter. To exclude the possible effects of vasoconstriction on medial cross-sectional area and lumen area, we performed morphometrical analysis of pulmonary arteries after maximal vasodilatation and fixed the vessels in situ at standard intravascular pressures. By this way we are assured that an increase in medial cross-sectional area indeed reflects a strucrural increase of the medial cross-sectional area rather than active pulmonary vasoconstriction. Moreover, in those conditions a reduction of the lumen area reflects a structural reduction rather than a functional reduction of the lumen area as a consequence of pulmonary vasoconstriction.

Under these conditions MCT increased the medial cross-sectional area and media to lumen ratio of pulmonary arteries with an external diameter between 30-100 $\mu \mathrm{m}$ and 101-200 $\mu \mathrm{m}$. The consequences for the lumen area, however, were different in these two categories of pulmonary arteries. As expected, an increase in medial crosssectional area was associated with a reduction of the lumen area of pulmonary arteries with an external diameter between 101-200 $\mu \mathrm{m}$. The lumen area of pulmonary arteries with an external diameter between $30-100 \mu \mathrm{m} \mathrm{did}$, however, not change. This indicates that the type of pulmonary vascular remodeling in MCT-induced pulmonary hypertension differs in different segments of the pulmonary arterial tree.

In contrast to MCT, hypoxia only slightly increased the medial area and did not alter the lumen area of pulmonary arteries with an external diameter berween 30-200 $\mu \mathrm{m}$. Several studies have shown a significant increase in media thickness of muscular pulmonary arteries in chronic hypoxic rats whereas we only showed a trend to an increase of the medial cross-sectional area $(20,38)$. We assume that, in those studies in which pulmonary arteries were studied without fixation under standard intravascular pressure and without maximal vasodilatation, a significant part of the media thickening can be attributed to active pulmonary vasoconstriction rather than a structural increase in media thickness. Previous studies have shown that the development of an increase in the PAP and media thickening of pulmonary arteries differs in the hypoxia and MCT model $(11,20)$. Hypoxia induces a significant increase in the PAP and media thickness after 3 days, whereas in MCT-treated rats significant changes in the PAP and media thickne'ss were observed after 21 days. In these studies the level of PAP correlated with the degree of arterial wall thickness. The present study shows differences of pulmonary artery remodeling, not only between the rwo models but also in different segments of the pulmonary artery tree. This suggests that different mechanisms other than pressure contribute to pulmonary artery remodeling. 
These structural pulmonary vascular changes, such as an increase in medial cross-sectional area and a reduction of the lumen area in MCT-treated rats, correlate well with an increased PAP and right ventricular hypertrophy. Although chronic hypoxia also increased the PAP and induced right ventricular hypertrophy, the medial area only slightly increased in absence of changes of the lumen area. As stated earlier, vasoconstriction rather than structural vascular changes of muscular pulmonary arteries may contribute to hypoxia-induced pulmonary hypertension. Structural vascular changes of arterioles rather than small sized muscular pulmonary arteries could provide an alternative explanation for hypoxia-induced pulmonary hypertension as hypoxia increased the number of muscularized and partially muscularized arterioles. Hypoxia-induced polycythemia, however, could be a confounding factor, because an increase in blood viscosity contributes to an increase in pulmonary vascular resistance (39).

Previous studies have demonstrated that ACE inhibitors can at least partially prevent the development of MCT and hypoxia-induced pulmonary hypertension and structural pulmonary vascular changes $(9,27-32)$. In the present study the ACE inhibitor captopril did not prevent the MCT-induced increase in medial mass of muscular pulmonary arteries, had no effect on the lumen area, and did not reduce the percentage of muscularized arterioles. Moreover, captopril did not prevent MCTinduced increase in PAP and right ventricular hypertrophy. We therefore believe that angiotensin II (AII) is an unimportant modulator of structural pulmonary vascular changes in this model. This hypothesis is supported by a previous report of Cassis who showed that the specific nonpeptide AII type 1 receptor antagonist, Losartan, could nor prevent MCT-induced PAP and structural pulmonary vascular changes (10).

In contrast to the lack of effect in MCT-treated rats, captopril prevented the increase in medial cross-sectional area of pulmonary arteries in chronic hypoxic rats and reduced the percentage of muscularized arterioles. This effect was, however, without a decrease in PAP or right ventricular hypertrophy. From this observation we conclude that the effect of captopril on the pulmonary vascular structure is a direct one and not due to an effect on pulmonary hemodynamics.

There may be several explanations for the inability of capropril to reduce PAP and right ventricular hypertrophy despite its potential to prevent an increase in medial cross-sectional area and reduce the percentage of muscularized arterioles. As previously stated, one possibility is that the increased blood viscosity due to polycythemia is responsible for the increased PAP and right ventricular hypertrophy, as captopril had no effect on the increased hematocrit in chronic hypoxic rats. Another possibility is that, despite a significant reduction of the percentage of muscular arterioles in captopril treated hypoxic rats, the percentage of muscularized and partially muscularized arterioles is still significantly increased compared to control rats (Figure 2). The vascular tone of these muscularized and partially muscularized arterioles may, even under normoxic conditions, still be increased and therefore contribute to a sustained increased PAP (40).

One of the limitations of this study is that we did not analyze the lumen area of arterioles because it is technically impossible to perform on these small vessels the rype 
of morphometrical analysis that was performed on muscular arteries. To optimize morphometrical analysis of pulmonary artery dimensions we compared pulmonary arteries with approximately the same external diameter. Within each experimental group we therefore analyzed two categories of pulmonary arteries (30-100 and 101-200 $\mu \mathrm{m})$, with comparable median external diameters between the groups.

In conclusion, this study demonstrates that the type of pulmonary artery remodeling in chronic hypoxic and MCT-treated rats is heterogeneous, not only between the groups but also in different segments of the pulmonary arterial tree. Moreover, these data suggest that AII plays a role in hypoxia but not in MCT-induced pulmonary artery remodeling. Finally, we showed that morphometric analysis of structural changes of muscular pulmonary arteries, in the rat hypoxia and MCT models of pulmonary hypertension, under optimal conditions only reveals a limited correlation between changes in pulmonary artery structure and changes in pulmonary artery pressure. Other factors like vasoconstriction or structural vascular changes at the level of arterioles may play a more important role in the increase in pulmonary artery pressure.

\section{REFERENCES}

1. Klinger JR, Hill NS. Right ventricular dysfunction in chronic obstructive pulmonary disease. Evaluation and management. Chest 1991;99:715-723.

2. Weitzenblum E, Kessler R, Oswald M, Fraisse P. Medical treatment of pulmonary hypertension in chronic lung disease. Eur. Respir. J. 1994;7:148-152.

3. D'Alonzo GE, Barst RJ, Ayres SM, et al. Survival in patients with primary pulmonary hypertension. Results from a national prospective registry. Ann. Intern. Med. 1991;115:343-349.

4. Rabinovitch M, Haworth SG, Castaneda AR, Nadas AS, Reid LM. Lung biopsy in congenital heart disease: a morphometric approach to pulmonary vascular disease. Circulation 1978;58:1107-1122.

5. Bush A, Busst CM, Haworth SG, et al. Correlations of lung morphology, pulmonary vascular resistance, and outcome in children with congenital heart disease. Br. Heart J. 1988:59:480-485.

6. Frescura $C$, Thiene G, Franceschini $E$, et al. Pulmonary vascular disease in infants with complete atrioventricular sepral defect. Int. J. Cardiol. 1987;15:91-100.

7. Haworth SG. Pulmonary vascular disease in ventricular septal defect: Structural and functional correlations in lung biopsies from 85 patients, with outcome of intracardiac repair. J. Pathol. 1987;152:157-168.

8. Haworth SG. Pulmonary vascular bed in children with complete atrioventricular septal defect: Relation between structural and hemodynamic abnormalities. Am. J. Cardiol. $1986 ; 57: 833-839$. 
9. Clozel JP, Saunier C, Hartemann D, Fischli W. Effects of cilazapril, a novel angiotensin converting enzyme inhibitor, on the structure of pulmonary arteries of rats exposed to chronic hypoxia. J. Cardiovasc. Pharmacol. 1991;17:36-40.

10. Cassis LA, Rippetoe PE, Soltis EE, Painter DJ, Firz R, Gillespie MN. Angiciensin II and monocrotaline-induced pulmonary hypertension: effect of losartan (DuP 753), a. nonpeptide angiotensin type 1 receptor antagonist. J. Pharmacol. Exp. Ther. 1992;262:1168-1172.

11. Meyrick B, Gamble W, Reid L. Development of Crotalaria pulmonary hypertension: hemodynamic and structural study. Am. J. Physiol. 1980;239:H692-H702.

12. Rabinovitch M, Mullen M, Rosenberg HC, Maruyama K, O’Brodovich H, Olley PM. Angiotensin II prevents hypoxic pulmonary hypertension and vascular changes in rat. Am. J. Physiol. 1988;254:H500-H508.

13. Mulvany MJ, Baumbach GL, Aalkjaer C, et al. Vascular remodeling. Hypertension 1996;28:505-506.

14. Heagerty AM, Aalkjaer C, Bund SJ, Korsgaard N, Mulvany MJ. Small artery structure in hypertension: Dual processes of remodeling and growth. Hypertension 1993;21:391-397.

15. Thybo NK, Stephens N, Cooper A, Aalkjaer C, Heagerty AM, Mulvany MJ. Effect of antihypertensive treatment on small arteries of patients with previously untreated essential hypertension. Hypertension 1995;25:474-481.

16. Deng LY, Schiffrin EL. Effects of endothelin-1 and vasopressin on resistance arteries of spontaneously hypertensive rats. Am. J. Hypertens. 1992;5:817-822.

17. Thybo NK, Korsgaard N, Eriksen S, Christensen KL, Mulvany MJ. Dose-dependent effects of perindopril on blood pressure and small-artery structure. Hypertension 1994;23:659-666.

18. Norrelund H, Christensen KL, Samani NJ, Kimber P, Mulvany MJ, Korsgaard N. Early narrowed afferent arteriole is a contributor to the development of hypertension. Hyper. tension 1994;24:301-308.

19. Korsgaard N, Mulvany MJ. Cellular hypertrophy in mesenteric resistance vessels from renal hypertensive rats. Hypertension 1988;12:162-167.

20. Rabinovitch M, Gamble W, Nadas AS, Miettinen OS, Reid L. Rat pulmonary circula tion after chronic hypoxia: hemodynamic and structural features. Am. J. Physiol. 1979;236:H818-H827.

21. Hislop A, Reid L. New findings in pulmonary arteries of rats with hypoxia-induced pulmonary hypertension. Br. J. Exp. Pathol. 1976:57:542-554.

22. Meyrick B, Reid L. Hypoxia and incorporation of $3 \mathrm{H}$-thymidine by cells of the rat pulmonary arteries and alveolar wall. Am. J. Pathol. 1979;96:51-70.

23. Wohrley JD, Frid MG, Moiseeva EP, Orton EC, Belknap JK, Stenmark KR. Hypoxia selectively induces proliferation in a specific subpopulation of smooth muscle cells in the bovine neonatal pulmonary arterial media. J. Clin. Invest. 1995:96:273-281.

24. Stenmark KR, Durmowicz AG, Roby JD, Mecham RP, Parks WC. Persistence of the fetal pattern of tropoelastin gene expression in severe neonatal bovine pulmonary hypertension. J. Clin. Invest. 1994;93:1234-1242. 
25. Prosset IW, Stenmark KR, Suthar M, Crouch EC, Mecham RP, Parks WC. Regional heterogeneity of elastin and collagen gene expression in intralobar arteries in response to hypoxic pulmonary hypertension as demonstrated by in situ hybridization. $A m$. J. Pathol. 1989;135:1073-1088.

26. Durmowicz AG, Parks WC, Hyde DM, Mecham RP, Stenmark KR. Persistence, re-expression, and induction of pulmonary arterial fibronectin, tropoelastin, and type I procollagen mRNA expression in neonatal hypoxic pulmonary hypertension. $\mathrm{Am}$. J. Pathol. 1994;145:1411-1420.

27. McKenzie JC, Hung K, Mattioli L, Klein RM. Reduction in hypertension-induced protein synthesis in the rat pulmonary trunk after treatment with teprotide (SQ20881) (41959). Proc. Soc. Exp. Biol. Med. 1984;177:377-382.

28. Zakheim RM, Martioli L, Molteni A, Mullis KB, Bartley J. Prevention of pulmonary vascular changes of chronic alveolar hypoxia by inhibition of angiorensin I-converting enzyme in the rat. Lab. Invest. 1975;33:57-61.

29. Molteni A, Ward WF, Ts'ao CH, Solliday NH. Monocrotaline-induced cardiopulmonary damage in rats: amelioration by the angiotensin-converting enzyme inhibitor CL242817. Proc. Soc. Exp. Biol. Med. 1986;182:483-493.

30. Morrell NW, Morris KG, Stenmark KR. Role of angiorensin-converting enzyme and angiotensin II in development of hypoxic pulmonary hypertension. Am. J. Physiol. 1995;269:H1186-H1194.

31. Kentera D. Susic D. Cvetkovic A. Djordjevic G. Effects of SQ 14.225, an orally active inhibitor of angiotensin-converting enzyme, on hypoxic pulmonary hypertension and right ventricular hypertrophy in rats. Basic. Res. Cardiol. 1981;76:344-351.

32. Nong Z, Stassen J-M, Moons L, Collen D, Janssens S. Inhibition of tissue angiotensinconverting enzyme with Quinapril reduces hypoxic pulmonary hypertension and pulmonary vascular remodeling. Circulation 1996;94:1941-1947.

33. Rabinovitch M, Gamble W, Nadas AS, Mietrinen OS, Reid L. Rat pulmonary circula tion after chronic hypoxia: hemodynamic and structural fearures. Am. J. Physiol. 1979;236:H818-H827.

34. Wallenstein S, Zucker CL, Fleiss JL. Some statistical mechods useful in circularion research. Circ. Res. 1980;47:1-9.

35. Kay JM, Suyama KL, Keane PM. Failure to show decrease in small pulmonary blood vessels in rats with experimental pulmonary hypertension. Thorax 1982;37:927-930.

36. Kay JM, Keane PM, Suyama KL. Pulmonary hypertension induced in rats by monocrotaline and chronic hypoxia is reduced by p-chlorophenylalanine. Respiration 1985;47:48-56.

37. Hislop A, Reid L. Changes in the pulmonary arteries of the rat during recovery from hypoxia-induced pulmonary hypertension. Br. J. Exp. Pathol 1977;58:653-662.

38. Meyrick B. Reid L. Hypoxia-induced structural changes in the media and adventitia of rat hilar pulmonary artery and their regression. Am. J. Pathol. 1980;100:151-178. 
39. Janssens SP, Thompson BT, Spence CR, Hales CA. Polycythemia and vascular remodeling in chronic hypoxic pulmonary hypertension in guinea pigs. J. Appl. Physiol. 1991;71:2218-2223.

40. Barer G, Emery C, Stewart A, Bee D. Howard P. Endothelial control of the pulmonary circulation in normal and chronically hypoxic rats. J. Physiol. Lond. 1993:463:1-16. 

CHAPTER 4

Dissociation of pulmonary vascular remodeling and right ventricular pressure in tissue ACE-deficient mice in conditions of chronic alveolar hypoxia 
The present study was designed to characterize the effects of chronic hypoxia on pulmonary vascular remodeling and its functional consequences in tissue ACE-deficient mice. Based on the data obtained by pharmacological inhibition of ACE in rats we hypothesized that under chronic hypoxic conditions tissue ACE-deficient mice show less remodeling of pulmonary arterioles as compared to wild-type mice, but have equally increased right ventricular pressures. Wild-type and tissue ACE-deficient mice were exposed to chronic hypoxia for 4 weeks. Under normoxic conditions the percentages of non-muscular, partially muscularized and completely muscularized arterioles as well as the mean right ventricular pressure and right ventricular weight were comparable in wild-type and tissue ACE-deficient mice. Under chronic hypoxic conditions the percentage of completely muscularized arterioles was lower in tissue ACE-deficient mice compared to wild-type animals (20.4 \pm 7.9 vs $36.2 \pm 11.6 \%, p<0.01)$, whereas the percentage of partially muscularized arterioles had increased $(51.7 \pm 11.5$ vs $40.8 \pm 5.6 \%, p<0.05)$. The mean right ventricular pressure and the extent of right ventricular hypertrophy were not different in chronic hypoxic wild-type and tissue ACE-deficient mice. We conclude that pulmonary vascular remodeling, but not mean right ventricular pressure is attenuated in chronic hypoxic tissue ACE-deficient mice compared to chronic hypoxic wildtype littermates. 


\section{INTRODUCTION}

Chronic alveolar hypoxia is associated with the development of pulmonary hypertension and right ventricular hypertrophy. Both hypoxia-induced vasoconstriction and structural pulmonary vascular changes contribute to an increased pulmonary artery pressure. Hypoxia-induced structural pulmonary vascular changes include increased medial thickness of small muscular pulmonary arteries and peripheral extension of smooth muscle cells into normally non-muscular arterioles, commonly called pulmonary vascular remodeling $(1,2)$. These structural changes are a result of vascular smooth muscle cell proliferation, hypertrophy and deposition of extracellular matrix components (3-6). In the systemic circulation angiotensin II (AII) has been shown to be a mediator of vascular smooth muscle cell growth and/or proliferation (7-9) and may therefore also be seen as a potential modulator of the structural pulmonary vascular changes associated with pulmonary hypertension. During the development of hypoxic pulmonary hypertension local ACE expression is increased in the walls of small pulmonary arteries (10). Most AII is produced in the lungs through the conversion of Angiotensin I into AII by angiotensin I-converting-enzyme (ACE) at the membrane of endothelial cells. Several studies have investigated the effects of ACE inhibitors on pulmonary artery pressure and pulmonary artery structure under normoxic and chronic hypoxic conditions. Under normoxic conditions ACE inhibition has no effect on rat pulmonary artery pressure and pulmonary artery structure $(11,12)$. Most studies report that in chronic hypoxic rats $\mathrm{ACE}$ inhibitors prevent or attenuate the development of pulmonary artery medial thickening and/or muscularizarion of arterioles (12-14). The literature is, however, less clear on the effects of ACE inhibitors on pulmonary artery pressure. In chronic hypoxic rats it has been shown that the ACE inhibitor cilazapril completely prevents medial thickening of pulmonary arteries without a significant effect on pulmonary artery pressure and right ventricular weight (15). Data from our group show that the ACE inhibitor captopril prevented an increase in medial cross-sectional area of small $(30-100 \mu \mathrm{m})$ muscular pulmonary arteries in chronic hypoxic rats and reduced the percentage of muscularized arterioles (16). This effect occurred, as in the study by Clozel and co-workers (15), without a decrease in pulmonary artery pressure or right ventricular hypertrophy. Others, however, did report a preventive effect of ACE inhibition on the increase in pulmonary artery pressure during hypoxia (12-14).

Recently, tissue ACE-deficient mice have been generated by introducing a modified ACE allele into a mouse line (17). Mice homozygous for this mutant allele $(-/$ ) have significant plasma ACE activity, but no tissue-bound enzyme. They also have a low systemic blood pressure, renal vascular thickening, and a urine concentrating defect. There are no data available on the pulmonary vasculature although this mouse strain provides an excellent tool for studying the role of tissue ACE in the development of pulmonary vascular remodeling and pulmonary hypertension under chronic hypoxic conditions. Based on the data in rats (16) we hypothesized that under 
normoxic conditions tissue ACE-deficient mice have a normal pulmonary arrery pressure and no structural pulmonary vascular changes under normoxic conditions. Under chronic hypoxic conditions, however, they show less remodeling of arterioles compared to wild-type mice, yet pulmonary artery pressure increases to a comparable extent as in hypoxic wild-type mice.

\section{METHODS}

\section{Experimental animals}

We studied mice with a targeted disruption of the ACE gene (homozygous mutant $(-/ /))$ on a C57BL/6J genetic background and wild-type $\left(+/_{+}\right)$littermates. Male and female mice with an age of 6-10 weeks, weighing 18 to $30 \mathrm{~g}$ were used for the experiment. The generation of these mice has been described by Esther and co-workers (17). They were a gift from Dr. Bernstein (Atlanta, Georgia, USA). At an age of 21 days the offspring was weaned and genotyped by PCR analysis (18). Animals were provided food (RMH-TM; Hope Farms, Woerden, The Netherlands) and water ad libitum and were maintained on a 12-hour light/dark cycle. The experiments were performed according to institutional guidelines for the use and care of animals and approved by the local ethical committee. All mice were killed 4 weeks after the start of the experiment.

\section{Exposure to chronic hypoxia}

At day 1 mice were placed into a normobaric chamber for 4 weeks. The chamber was maintained at $10 \% \mathrm{O}_{2}$, which was accomplished by controlling the inflow rates of room air and nitrogen. The $\mathrm{O}_{2}$ concentration was checked every day using an $\mathrm{O}_{2}$ analyzer (AVL 993, AVL LIST GmbH, Graz, Austria). Each day the chamber was opened for approximately 1 minute to replenish food and water.

\section{Experimental groups}

A total of 41 mice were investigated. Wild type $\left(+/ /_{+}\right)$and tissue ACE-deficient $\left(-/_{-}\right)$ mice were studied under normoxic $\left(-I_{-} n=8 ;+I_{+} n=11\right)$ and chronic hypoxic $\left(-I_{-} n=\right.$ $10 ;+, n=12$ ) conditions. Groups were matched for age and gender.

Hemodynamic studies

At the end of the experiment the mice were anesthetized $(110 \mathrm{mg} / \mathrm{kg}$ pentobarbital, intraperitoneally, Sanofi Sante B.V., Maassluis, The Netherlands) and placed on a heated table. The trachea was intubated, and the lungs were ventilated with room air 
at $80 \mathrm{strokes} / \mathrm{min}$ and $1.5 \mathrm{ml}$ tidal volume. A parasternal thoracotomy from the xiphoid to the pretracheal region was performed. A needle (outer diameter $0.6 \mathrm{~mm}$ ) connected to a silastic tube was placed into the right ventricular cavity by direct puncture of the right ventricle. The tube was connected to a pressure monitor. Following stabilization for 10 minutes, the right ventricular systolic and diastolic pressures were recorded during a 10-min period using a miniature pressure transducer (CP-01); Century Technology, Inglewood, CA) and a computerized data-acquisition system (HDAS; Instruments Services Dept., Maastricht University, Maastricht, The Netherlands). Mean right ventricular pressure (MRVP) was calculated by digital integration.

\section{Assessment of right ventricular hypertrophy}

The heart was dissected free and both atria, the aorta and the pulmonary trunk were removed. The right ventricle was separated from the left ventricle and the ventricular septum. Right ventricular hypertrophy was expressed as the ratio of the weight of the right ventricular wall (RV) and that of the left ventricular wall and ventricular septum $(\mathrm{LV}+\mathrm{S})$.

\section{Hematocrit}

After induction of anesthesia with pentobarbital, blood samples were obtained from an orbita puncture. The hematocrit was determined using a micro capillary centrifuge for five minutes.

\section{Assessment of muscularization of arterioles}

After the hemodynamic studies $10 \%$ phosphate-buffered formalin ( $\mathrm{pH} 7.4)$ was infused into the lung via a trachea tube, at a pressure of $20 \mathrm{~cm} \mathrm{H}_{2} \mathrm{O}$. Subsequently the heart and lungs were excised and fixed for 24 hours in $10 \%$ phosphate-buffered formalin ( $\mathrm{pH} 7.4$ ). Both lungs were paraffin embedded and $4-\mu \mathrm{m}$ sections, parallel to the hilus, were stained with a monoclonal antibody against $\alpha$-smooth muscle actin (DAKO, dilution 1:500) using Diaminobenzidine as the chromogen and hemaroxylin as the counter stain (19).

At $\times 400$ magnification 50 alveolar wall and alveolar duct vessels were counted, and the proportion of muscularized and partially muscularized vessels was calculated and recorded as a percentage of the total alveolar wall and alveolar ducr vessels. A completely muscularized arteriole was defined as an arteriole with $\alpha$-smooth muscle actin-positive cells forming a subendothelial layer of more than $50 \%$ of its circumference. A partially muscularized arteriole was defined as an arteriole where $\alpha$-smooth muscle actin-positive cells formed a subendothelial layer of less than $50 \%$ of its circumference. If $\alpha$-smooth muscle actin staining was absent, the vessel was termed 
nonmuscular. This analysis was performed by a single observer (RJvS) who was unaware of the experimental conditions.

\section{Statistical analysis}

All results were expressed as means \pm SD. Differences berween groups were determined using a non-parametric Mann-Whitney $U$ test with a Bonferroni correction for multiple group comparison (20). Statistical significance was defined at $\mathrm{p}<0.05$.

\section{RESULTS}

\section{Cardiac weights}

Under normoxic conditions right ventricular weight and the ratio of right ventricular weight to body weight was comparable in wild-type and tissue ACE-deficient mice. In both wild-type and tissue ACE-deficient mice chronic hypoxic conditions induced right ventricular hypertrophy. The extent of right ventricular hypertrophy did not differ between wild-type and tissue ACE-deficient hypoxic mice (Table 1).

The mean weight of the $\mathrm{LV}+S$ was lower in both normoxic and hypoxic tissue ACE-deficient mice compared to normoxic and hypoxic wild-type mice (normoxia $-I_{-}$ $=87 \pm 7.7 \mathrm{mg}$, normoxia ${ }^{+} I_{+}=114 \pm 17 \mathrm{mg}, \mathrm{p}<0.01$; hypoxia $-I_{-}=103 \pm 28 \mathrm{mg}$, hypoxia $\left.t_{+}=135 \pm 20 \mathrm{mg}, \mathrm{P}<0.01\right)$. The ratio of the $\mathrm{LV}+\mathrm{S} / \mathrm{BW}$, however, was not different berween tissue ACE-deficient mice compared to wild-type mice (normoxia $-I_{-}=3.8 \pm 0.2$, normoxia ${ }^{+} I_{+}=4.3 \pm 0.6 ;$, $y$ poxia $I_{-}=5.2 \pm 1.0$, hypoxia ${ }_{+}=5.8 \pm 0.8$ ). Because the mean right ventricular weights in normoxic tissue ACE-deficient and wild-type mice were also comparable, the higher ratio of $R V / L V+S$ in tissue ACF-deficient mice is mainly due to their lower $\mathrm{LV}+\mathrm{S}$ (normoxia ${ }^{+}{ }_{+}=0.23 \pm 0.03$ vs normoxia $\left.-I_{-}=0.28 \pm 0.05, \mathrm{p}<0.05\right)$.

\section{Hematocrit}

In wild-type mice hypoxia caused hematocrit values to increase from $41 \pm 3.7 \%$ to 70 $\pm 5.5 \%(\mathrm{p}<0.01)$. Also in tissue ACE-deficient mice hypoxia caused an increase in hematocrit values from $39 \pm 2.9 \%$ to $62 \pm 6.2 \%$ ( $p<0.01$ ). The hematocrit in hypoxic, but not in normoxic wild-type mice, was higher than the hematocrit in hypoxic tissue ACE-deficient mice $(70 \pm 5.5$ vs $62 \pm 6.2 \%, \mathrm{p}<0.05)$. 


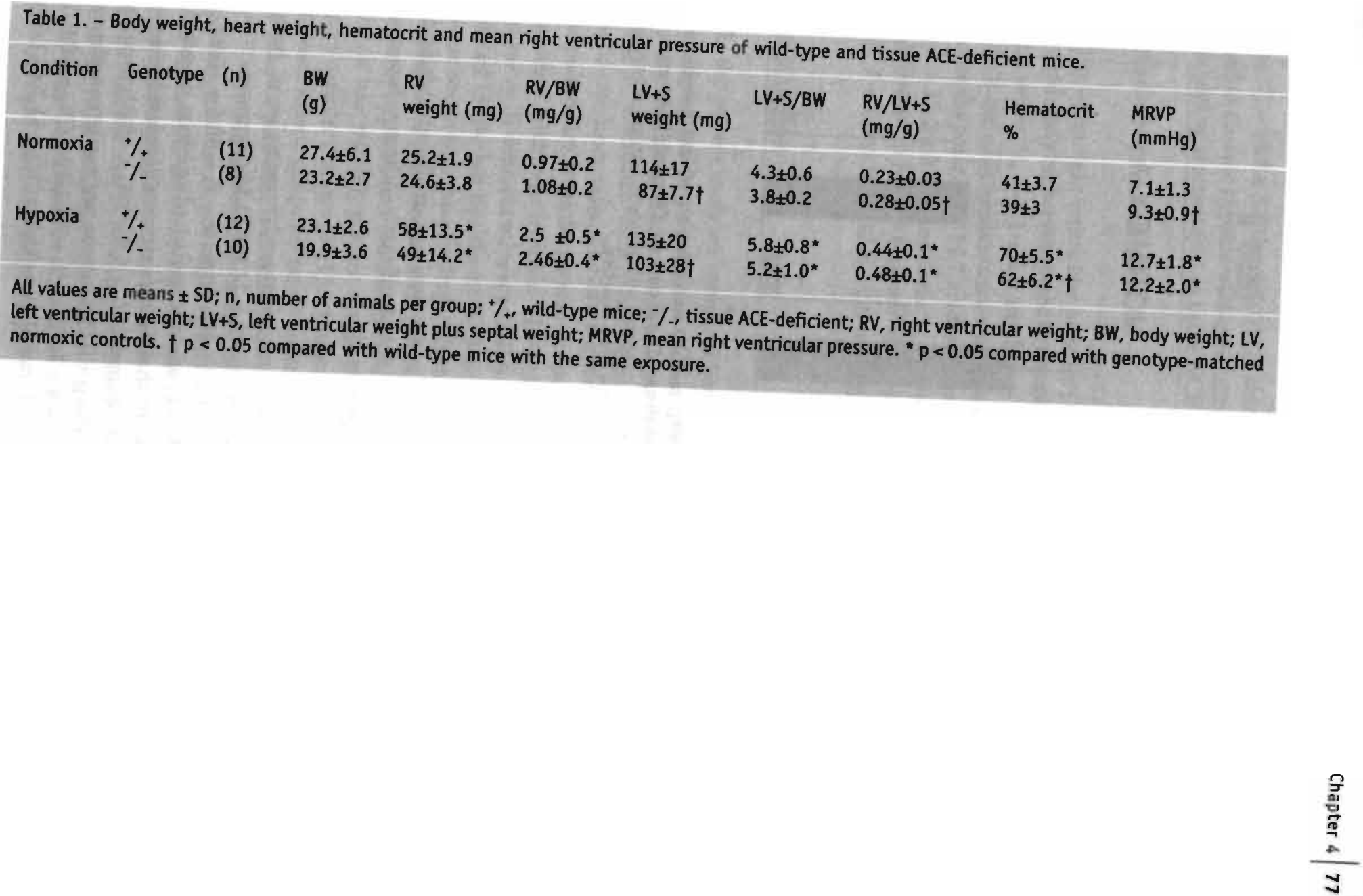




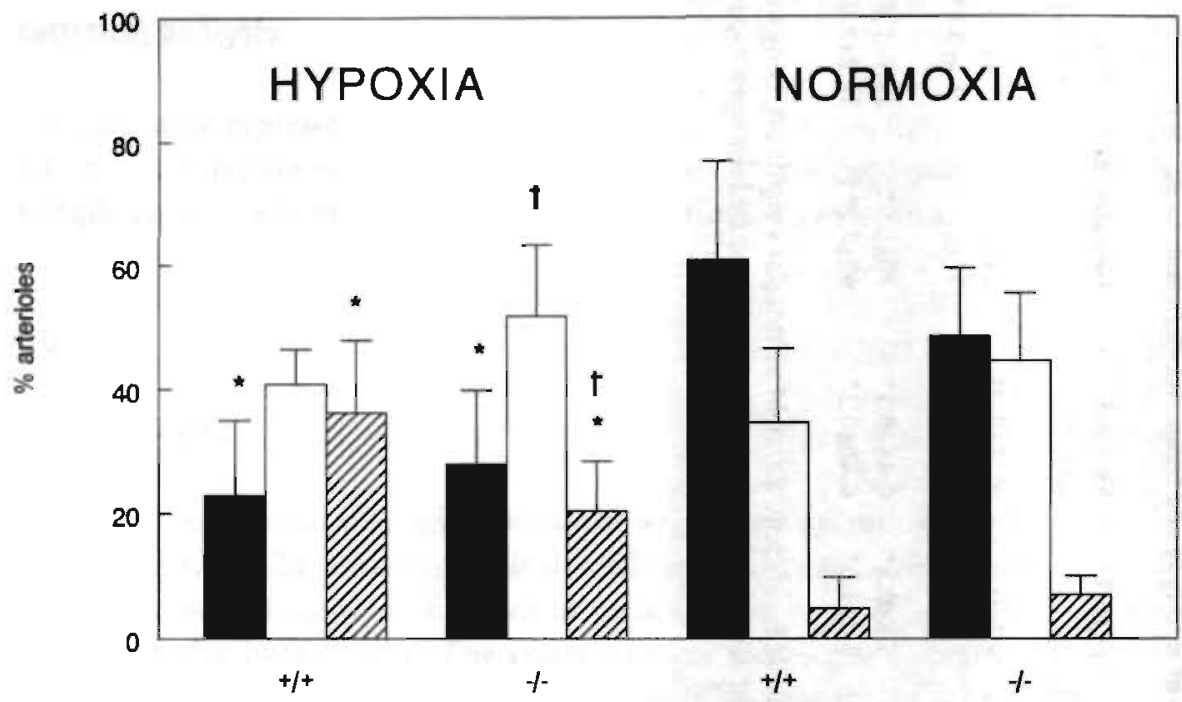

Figure 1. - The percentage of non-muscular (NM), partially muscularized (PM) and completely muscularized $(M)$ arterioles in wild-type $(+/+)$ and tissue ACE-deficient $\left.(-/)_{-}\right)$normoxic and hypoxic mice. All values are presented as means \pm SD. ${ }^{*} p<0.05$ compared with genotype-matched normoxic mice. $f p<0.05$ compared with wild-type mice with the same exposure.

Pulmonary vascular morphology

\section{Normoxia}

Under normoxic conditions the percentage of nonmuscular, partially muscularized and completely muscularized arterioles was not significantly different between wild-type and tissue ACE-deficient mice (Figure 1).

\section{Chronic hypoxia}

Chronic hypoxia decreased the percentage of nonmuscular arterioles in both wild-type and tissue ACE-deficient mice (hypoxia ${ }^{+} \tau_{+}=22.9 \pm 12.5 \%$, normoxia ${ }_{+}=$ $60.9 \pm 16.2 \%, \mathrm{p}<0.01$; hypoxia $-I_{-}=27.9 \pm 11.9 \%$, normoxia $-I_{-}=48.5 \pm 10.9 \%$, $\mathrm{p}<0.01$ ) (Figure 1). The percentage of completely muscularized arterioles increased in both wild-type and tissue ACE-deficient chronic hypoxic mice compared to normoxic mice (hypoxia ${ }_{+}=36.2 \pm 11.6 \%$, normoxia ${ }_{+} I_{+}=4.8 \pm 5 \%, \mathrm{p}<0.01$; hypoxia $-I_{-}=20.4 \pm 7.9 \%$, normoxia $\left.-I_{-}=7 \pm 3 \%, \mathrm{p}<0.01\right)$, but the percentage completely muscularized arterioles was lower $\left(-l_{-}=20.4 \pm 7.9 \%\right.$ vs $\left.t_{+}=36.2 \pm 11.6 \%, p<0.01\right)$ and the percentage of partially muscularized arterioles was higher $\left(-I_{-}=51.7 \pm 11.5 \%\right.$ 
$\left.\mathrm{vs}^{+} /_{+}=40.8 \pm 5.6 \%, \mathrm{p}<0.05\right)$ in chronic hypoxic tissue ACE-deficient mice compared to chronic hypoxic wild-type mice. Thus hypoxia-induced pulmonary vascular remodeling is attenuated in tissue ACE-deficient mice.

Hemodynamic studies

The mean right ventricular pressure (MRVP) in normoxic tissue ACE-deficient mice was slightly higher compared to normoxic wild-type mice (normoxia $I_{-}=9.3 \pm 0.9 \mathrm{vs}$ normoxia $t_{+}=7.1 \pm 1.3 \mathrm{mmHg}, \mathrm{p}<0.01$ ). MRVP in both wild-type and tissue ACE-deficient hypoxic mice was increased compared to genotype matched normoxic mice (hypoxia ${ }^{+}{ }_{+}=12.7 \pm 1.8$ vs normoxia ${ }^{+} I_{+}=7.1 \pm 1.3 \mathrm{mmHg}, \mathrm{p}<0.01$; hypoxia $-I_{-}=12.2 \pm 2.0$ vs normoxia ${ }^{-} I_{-}=9.3 \pm 0.9 \mathrm{mmHg}, \mathrm{p}<0.05$ ) (Table 1$)$. There was no difference in MRVP between wild-type and tissue ACE-deficient hypoxic mice $\left({ }^{+} t_{+}=\right.$ $12.7 \pm 1.8 \mathrm{vs}^{-} /_{-}=12.2 \pm 2.0 \mathrm{mmHg}$ ).

\section{DISCUSSION}

In the present study we compared hemodynamic and structural pulmonary vascular changes in wild-type and tissue ACE-deficient mice under normoxic and chronic hypoxic conditions. The major finding of this study is that pulmonary vascular remodeling is attenuated in hypoxic tissue ACE-deficient mice compared to hypoxic wild-type littermates. The data suggest that, in mice, local production of AII by ACE in pulmonary arterioles plays an important role in pulmonary vascular remodeling secundary to chronic hypoxia. The residual structural pulmonary vascular changes in tissue ACE-deficient mice is probably due to the activity of plasma $\mathrm{ACE}$, which is reduced (30\%) but not absent in these mice. Experiments performed in hypoxic rats corroborate with these findings. Morrell and co-workers have demonstrated that ACE expression is increased in small pulmonary arteries of rats with hypoxia-induced putmonary hypertension (10). Moreover, several studies have shown that ACE inhibitors can at least partially prevent the development of hypoxia-induced structural pulmonary vascular changes $(11,13,15)$ most probably via inhibition of pulmonary vascular smooth muscle cell proliferation and/or growth (12), an effect that is angiocensin rype 1 receptor mediated (21) and apparently pressure independent (16).

Another interesting result of the present study is that the mean right ventricular pressure and the extent of right ventricular hypertrophy was not different in wild-type and tissue ACE-deficient hypoxic mice despite a significant reduction of completely muscularized arterioles in tissue ACE-deficient hypoxic mice. This result is in accordance with the results from a previous study from our group in which we demonstated that the ACE inhibitor captopril also attenuated the increase in the percentage of completely muscularized arterioles, without any effect on the pulmonary artery pressure and right ventricular hypertrophy in chronic hypoxic rats (16). A possible explana- 
tion for the dissociarion between structural ch.ınges of arterioles and right ventricular pressure is that other structural changes like medial thickening of muscular pulmonary arteries (external diameter between 30-200 $\mu \mathrm{m}$ ) contribute to an increase in MRVP. In rats, we have shown that chronic hypoxia only slightly increased the media crosssectional area without a change of the lumen area (16) suggesting that neither changes in media cross-sectional area nor lumen area are significant contributors to hypoxiainduced pulmonary hypertension. In the mouse lung, the number of these muscular pulmonary arteries suitable for morphometrical analyses is too low to allow reliable measurements with respect to total vessel area, medial area and lumen area. Another explanation for the dissociation between arteriolar structure and right ventricular pressure could be the fact that despite a significant reduction of the percentage of completely muscularized arterioles in hypoxic tissue ACE-deficient mice, the percentage of partially muscularized arterioles was significantly increased compared to hypoxic wild-type mice. Constriction of these partially muscularized arterioles may, even under normoxic conditions, obscure potential effects of a reduced percentage of completely muscularized arterioles on the MRVP and right ventricular hypertrophy.

Since the mean right ventricular pressure and the extent of right ventricular hypertrophy was comparable in wild-rype and tissue ACE-deficient hypoxic mice, it is unlikely that right ventricular AII formation plays a crucial role in the development of right ventricular hypertrophy secondary to hypoxia-induced pulmonary hypertension. This would argue against the suggestion of Morrell and co-workers that locally increased right ventricular ACE activity and expression may play a role in the pathogenesis of right ventricular hypertrophy secondary to hypoxic pulmonary hypertension (22).

Hematocrit levels were increased in hypoxic wild-type mice as compared to hypoxic tissue ACE-deficient mice. It is, however, unlikely that a difference in the hematocrit between wild-type and tissue ACE-deficient hypoxic mice obscures a potential effects of a reduced percentage of completely muscular arterioles on the MRVP and right ventricular hypertrophy. First of all Steudel and coworkers have shown that in hypoxic mice, even a very high hematocrit (65-75\%) does not impose sufficient additional work load on the right ventricle to cause hypertrophy (23). Moreover, normalization of the data for hematocrit would result in a lower MRVP in hypoxic tissue ACE-deficient mice compared to wild-rype hypoxic mice.

An unexpected observation was a slightly higher MRVP in normoxic tissue ACE-deficient mice compared to normoxic wild-type mice. This is in contrast with our hypothesis based on previous studies that have shown that in rats under normoxic conditions ACE inhibition has no effect on pulmonary artery pressure $(11,12)$. The mechanism resulting in a higher MRVP in normoxic tissue ACE-deficient mice is unclear. It is known that tissue ACE-deficient mice have a low systemic blood pressure (17). It is, however, unlikely that the higher MRVP in tissue ACE-deficient mice is secondary to left ventricular failure because the cardiac output in these mice is comparable with wild-type mice (W. Aartsen, personal communication). 
In summary, this study demonstrates that pulmonary vascular remodeling is attenuated in hypoxic tissue ACE-deficient mice compared to hypoxic wild-rype littermates which implies that local production of AII by ACE in pulmonary arterioles plays an important role in the pathogenesis of pulmonary vascular remodeling secundary to chronic hypoxia, but not in hypoxia-induced pulmonary hypertension. Local AII formation does not seem to play a crucial role in the development of right ventricular hypertrophy.

\section{REFERENCES}

1. Hicken $P$, Heath $D$, Brewer $D B$, Whitaker W. The small pulmonary arteries in emphy sema. J. Pathol. Bacteriol. 1965;90:107-114.

2. Rabinovitch M, Gamble W, Nadas AS, Miettinen OS, Reid L. Rat pulmonary circulation after chronic hypoxia: hemodynamic and structural features. Am. J. Physiol. 1979:236(6):H818-H827.

3. Prosser IW, Stenmark KR, Surhar M, Crouch EC, Mecham RP, Parks WC. Regional heterogeneity of elastin and collagen gene expression in intralobar arteries in response to hypoxic pulmonary hypertension as demonstrated by in situ hybridization. Am. J. Pathol. 1989;135:1073-1088.

4. Mecham RP, Stenmark KR, Parks WC. Connective tissue production by vascular smooth muscle in development and disease. Chest 1991:99:435-47S.

5. Botney MD, Liptay MJ, Kaiser LR, Cooper JD, Parks WC, Mecham RP. Active collagen synthesis by pulmonary arteries in human primary pulmonary hypertension. Am. J. Pathol. 1993;143:121-129.

6. Stenmark KR, Dempsey EC, Badesch DB, Frid M, Mecham RP, Parks WC. Regulation of pulmonary vascular wall cell growth: developmental and site-specific heterogeneiry. Eur. Respir. Rev. 1993;3:629-637.

7. Geisterfer AAT, Peach MJ, Owens GK. Angiotensin II induces hypertrophy, not hyperplasia, of cultured rat aortic smooth muscle cells. Circ. Res. 1988;62:749-756.

8. Daemen MJ, Lombardi DM, Bosman FT, Schwartz SM. Angiotensin II induces smooth muscle cell proliferation in the normal and injured rat arterial wall. Circ. Res. 1991;68:450-456.

9. Gibbons GH, Prart RE, Dzau VJ. Vascular smooth muscle cell hypertrophy vs. hyperplasia. Aurocrine transforming growth factor-beta 1 expression determines growth response to angiotensin II. J. Clin. Invest. 1992;90:456-461.

10. Morrell NW, Atochina EN, Morris KG, Danilov SM, Stenmark KR. Angiotensin converting enzyme expression is increased in small pulmonary arteries of rats with hypoxia-induced pulmonary hypertension. J. Clin. Invest. 1995;96:1823-1833.

11. Morrell NW, Morris KG, Stenmark KR. Role of angiorensin-converting enzyme and angiorensin II in development of hypoxic pulmonary hypertension. Am. J. Physiol. 1995;269:H1186-H1194. 
12. Nong Z, Stassen J-M, Moons L, Collen D, Janssens S. Inhibition of tissue angiotensinconverting enzyme with quinapril reduces hypoxic pulmonary hypertension and pulmonary vascular remodeling. Circulation 1996;94:1941-1947.

13. Zakheim RM, Mattioli L, Molteni A, Mullis KB, Bartley J. Prevention of pulmonary vascular changes of chronic alveolar hypoxia by inhibition of angiotensin I-converting enzyme in the rat. Lab. Invest. 1975;33:57-61.

14. Kentera D, Susic D, Cvetkovic A, Djordjevic G. Effects of SQ 14.225, an orally active inhibitor of angiotensin-converting enzyme, on hypoxic pulmonary hypertension and right ventricular hypertrophy in rats. Basic. Res. Cardiol. 1981;76:344-351.

15. Clozel JP, Saunier C, Hartemann D, Fischli W. Effects of cilazapril, a novel angiotensin converting enzyme inhibitor, on the structure of pulmonary arteries of rats exposed to chronic hypoxia. J. Cardiovasc. Pharmacol. 1991:17:36-40.

16. van-Suylen RJ, Smits JFM, Daemen MJAP. Pulmonary artery remodeling differs in hypoxia- and monocrotaline induced pulmonary hypertension. Am. J. Respir. Crit. Care Med. 1998;157:1423-1428.

17. Esther ('R, Marino EM. Howard TE, Machaud A, Corvol P, Capecchi MR, Bernstein $\mathrm{KF}$. The critical role of rissue angiotensin-converting enzyme as revealed by gene targeting in mice. J. Clin. Invest. 1997;99:2375-2385.

18. Esther CR Jr, Howard TE, Marino EM, Goddard JM, Capecchi MR, Bernstein KE. Mice lacking angiotensin-converting enzyme have low blood pressure, renal pathology, and reduced male fertility. Lab. Invest. 1996:74:953-965.

19. Willems IE, Havenith MG, De Mey JG, Daemen MJ. The alpha-smooth muscle actinpositive cells in healing human myocardial scars. Am. J. Pathol. 1994;145:868-875.

20. Wallenstein S, Zucker CL, Fleiss JL. Some statistical methods useful in circulation research. Circ. Res. 1980;47:1-9.

21. Morrell NW, Upton PD, Higham MA, Yacoub MH, Polak JM, Wharton J. Angiotensin II stimulates proliferation of human pulmonary artery smooth muscle cells via the AT1 receptor. Chest 1998:114(Suppl):90S-91S.

22. Morrell NW, Danilov SM, Satyan KB, Morris KG, Stenmark KR Right ventricular angiotensin converting enzyme activity and expression is increased during hypoxic pulmonary hypertension. Cardiovasc. Res. 1997;34:393-403.

23. Steudel W. Scherrer-Crosbie M, Bloch KD, Weimann J, Huang PL, Jones RC, Picard $\mathrm{MH}, \mathrm{Zapol}$ WM. Sustained pulmonary hypertension and right ventricular hypertrophy after chronic hypoxia in mice with congenital deficiency of nitric oxide synthase $3 . J$. Clin. Invest. 1998:101:2468-2477. 
CHAPTER 5

The DD genotype of the angiotensin converting enzyme gene is negatively associated with right ventricular hypertrophy in male patients with chronic obstructive pulmonary disease 
The renin angiotensin system plays an important role in the development of pulmonary artery remodeling and right ventricular hypertrophy in hypoxiainduced pulmonary hypertension as may occur in patients with COPD. Several polymorphisms of genes encoding for components of the renin angiotensin system such as the $\mathrm{M}^{235} \mathrm{~T}$ polymorphism in the angiotensinogen gene, the 287-base-pair insertion (I) / deletion (D) polymorphism at intron 16 of the ACE gene and the $A^{1166} C$ polymorphism in the angiotensin II type 1 receptor gene have been associated with an increased risk of cardiovascular diseases. With respect to the pulmonary circulation, only limited data exist on possible associations between polymorphisms of these genes and pulmonary hypertension and/or right ventricular hypertrophy. The objective of the present study was to investigate a possible relationship between polymorphisms of the renin angiotensin system and electrocardiographic evidence of right ventricular hypertrophy in patients with COPD. We therefore determined the angiotensinogen $\left(M^{235} \mathrm{~T}\right)$, angiotensin converting enzyme (I/D), and angiotensin II type 1 receptor $\left(A^{1166} C\right)$ genotypes in 87 patients with severe COPD and correlated these data with electrocardiographic parameters of right ventricular hypertrophy. Thirty-one patients ( $36 \%$ ) of 87 patients with COPD showed electrocardiographic evidence of right ventricular hypertrophy. In the male, but not in the female subgroup, the angiotensin converting enzyme DD genotype was negatively associated with electrocardiographic evidence of right ventricular hypertrophy (male: $\chi^{2}=3.8, p=0.05$, female: $\chi^{2}=0.05, p=0.82$ ). We found no associations between the investigated polymorphisms in the angiotensinogen and angiotensin II type 1 receptor genes and electrocardiographic evidence of right ventricular hypertrophy. 


\section{INTRODUCTION}

The development of pulmonary hypertension in patients with chronic obstructive pulmonary disease (COPD) is associated with hypoxia-induced pulmonary vasoconstricrion and pulmonary vascular remodeling (1). Recent studies suggest that the renin angiotensin system plays an important role in the development of both pulmonary artery remodeling and right ventricular hypertrophy in hypoxia-induced pulmonary hypertension. In rats, angiocensin converting enzyme (ACE) expression is increased in the walls of small pulmonary arteries and in the right ventricle during the development of hypoxia-induced pulmonary hypertension $(2,3)$. Moreover, in several animal models of hypoxia-induced pulmonary hypertension ACE inhibitors and angiotensin II type 1 receptor $\left(A G T_{1} R\right)$ antagonists attenuate or prevent the development of structural pulmonary artery changes and right ventricular hypertrophy (4-7). In patients with COPD most investigarors report a significantly higher serum ACE activity and plasma renin activity than in normoxic-normocapnic subjects $(8,9)$. Plasma ACE levels are also known to be elevated in subjects homozygous for the deletion allele (DD) of the ACE gene compared with heterozygotes (ID) or subjects homozygous for the insertion (II) allele $(10,11)$. The ACE DD genotype has been associated with a variery of cardiovascular diseases such as left ventricular hypertrophy, increased risk of myocardial infarction, cardiomyopathy, and coronary artery disease (11-15). Also, polymorphisms in other genes of the renin angiotensin system such as the $\mathrm{M}^{235} \mathrm{~T}$ polymorphism in the angiotensinogen (AGT) gene and the $\mathrm{A}^{1166} \mathrm{C}$ polymorphism in the angiotensin II type 1 receptor $\left(A G T_{1} R\right)$ gene have been associated with cardiovascular disease such as essential hypertension, coronary heart disease, and myocardial infarction (16-20). With respect to the pulmonary circulation, only limited data exist about an association between pulmonary hypertension, right ventricular hypertrophy, right ventricular function, and polymorphisms of the renin angiorensin system. One study reports that the ACE DD genotype is more prevalent in patients with primary pulmonary hypertension than the non-DD genotype (21). Although the degree of pulmonary hypertension was comparable, patients with the ACE DD genorype had a preserved cardiac output, a lower pulmonary vascular resistance, and lower right atrial pressures than did parients with the non-ACE DD genotype. This finding caused the investigators to suggest that the ACE DD genotype may permit the development of more extensive adaptive right ventricular hypertrophy in patients with primary pulmonary hypertension and may be seen as a marker of maintained right ventricular function. Associations between the $\mathrm{M}^{235} \mathrm{~T}$ polymorphism of the angiotensinogen gene or the $\mathrm{A}^{1166} \mathrm{C}$ polymorphism of the angiotensin II type 1 receptor gene and pulmonary hypertension have not been described. Also the extent to which these polymorphisms may contribute to the development of right ventricular hypertrophy in patients with COPD is unknown. Therefore we determined the distriburion of polymorphisms of the ACE gene (I/D), $A G T_{1} R$ gene $\left(A^{1166} \mathrm{C}\right)$, and $A G T$ gene $\left(\mathrm{M}^{235} \mathrm{~T}\right)$ in patients with severe stable COPD and correlated these data with electro- 
cardiographic paramerers of right ventricular hypertrophy. In analogy with the findings of Abraham and co-workers (21) and data derived from the systemic circulation we hypothesized that, also in patients with COPD, the ACE DD, $A G T_{1} R C C$, and the AGT TT genotype were positively correlated with right ventricular hypertrophy.

\section{METHODS}

\section{Study Population}

The study group consisted of 87 patients with COPD ( 62 male, 25 female), ranging from 46 to $79 \mathrm{yr}$ of age (mean, $65 \mathrm{yr}$ ), who were admitted to the pulmonary rehabilitation centre Hornerheide (Horn, The Netherlands). COPD was diagnosed in all patients according to the criteria of the American Thoracic Society (22), and FEV 1 was expressed as a percentage of the reference values $\left(\mathrm{FEV}_{1} \% \mathrm{pred}\right)<70 \%$ (23). All patients were stable at the time of the study. Patients with electrocardiographic evidence of severe left ventricular hypertrophy and/or myocardial infarction and patients with signs of left ventricular heart failure and/or heart murmers on physical examination were excluded. The research program was approved by the local ethical committee, and informed consent was obtained from all patients.

\section{Control Group}

The control group consisted of 95 subjects ( $42 \mathrm{male}, 53$ female) 41 to $70 \mathrm{yr}$ of age (mean, $50 \mathrm{yr}$ ). They had no clinical history of COPD and a FEV $1 \%$ pred within normal limits (mean $\mathrm{FEV}_{1} \%$ pred, 93\%; $\mathrm{SD}, 8$ ) and were, as the study group, all Caucasians and living in the same region.

\section{Pulmonary Function and Blood Gas Studies}

$\mathrm{FEV}_{1}$ was measured, using the pneumotachograph (Masterlab; Jaeger, Wurzburg, Germany). Values were expressed as a percentage of reference values. For arterial blood gas analysis blood was obtained by puncture of the radial artery while patients breathed room air. The $\mathrm{PaO}_{2}, \mathrm{PaCO}_{2}$, and $\mathrm{SaO}_{2}$ were measured using a blood gas analyzer (ABL 330; Radiometer, Copenhagen, Denmark).

\section{Electrocardiography}

To assess the presence of right ventricular hypertrophy a 12-lead electrocardiogram (ECG) was made. The following ECG criteria of right ventricular hypertrophy were used: (1) Incomplete or complete right bundle branch block. (2) Right axis deviation, defined as a frontal plane $Q R S$ axis of $>90$ degrees. (3) P wave in lead V1, II, or III of 
$>2.5 \mathrm{~mm}$ (P pulmonale). (4) $\mathrm{S}$ wave of $>1.5 \mathrm{~mm}$ in lead $\mathrm{I}$ in combination with a slow $R$ progression. (5) Clockwise rotation of the heart in the horizontal axis defined as a shift in the transition zone to V5 or beyond. (6) Low voltage QRS complex of $<5 \mathrm{~mm}$ in all the limb leads (II, III, and AVF).

The ECGs were evaluated by two cardiologists ( $\mathrm{PvP}$ and EC). In all parients agreement was reached. A positive ECG diagnosis suggestive for right ventricular. hypertrophy was accepted if two or more ECG criteria were present (24).

\section{Extraction and Amplification of Genomic DNA}

Genomic DNA was extracted from peripheral blood leukocytes with the QIAmp Blood Kit (QLAGEN Inc. Chatsworth, CA).

$A C E$ polymorphism. The ACE genotype was determined by the polymerase chain reaction (PCR) and subsequent gel electrophoresis of the PCR products using the method described by Rigat and colleagues (25). All DD genotypes were subjected to a second, independent PCR amplification to avoid mistyping in ID heterozygote subjects in which the I allele is sometimes suppressed (26). This second PCR did not identify any mistyping.

$A G T_{1} R$ polymorphism. The $\mathrm{A}^{1166} \mathrm{C}$ polymorphism was determined by $\mathrm{PCR}$ amplificarion of genomic DNA according to the method described by Bonnardeaux and colleagues (18).

AGT polymorphism. The $\mathrm{M}^{235} \mathrm{~T}$ variant was analyzed after $\mathrm{PCR}$ amplification of genomic DNA and restriction digestion with $\mathrm{Tth} 111 \mathrm{I}$ as described by Russ and colleagues (27).

\section{Statistical Analysis}

Differences in genorype distributions between patients with COPD and without electrocardiographic evidence of right ventricular hypertrophy were tested by the chi-square test $\left(\chi^{2}\right)$. Means of variables potentially related to the development of right ventricular hypertrophy were compared by two-sample $t$ test. Statistical significance was defined at $p<0.05$ (28). The Statistical Package for Social Sciences (release 7.5; SPSS Inc., Chicago, IL) was used for statistical analyses.

\section{RESULTS}

Pulmonary Function Test and Blood Gas Analysis

The mean $\mathrm{FEV}_{1}$ (\% pred) was 37\% (range 16 to $70 \%$ ). The mean $\mathrm{PaCO}_{2}$ and $\mathrm{PaO}_{2}$ were $5.7 \mathrm{kPa}$ (range 4.1 to 8.7 ) and $9.3 \mathrm{kPa}$ (range 6.3 to 12.7 ) respectively. The mean $\mathrm{Sa}_{\mathrm{O} 2}$ was $93.3 \%$ (range 80 to $98 \%$ ). 
Hematocrit and Age

The mean $\mathrm{Ht}$ was $4.3 .3 \%$ (range, 3.3 to $52 \%$ ). The mean age was $65 \mathrm{yr}$ (range, 46 to 79 уг).

\section{Medication}

Patients receiving antihypertensive drug treatment (ACE inhibitors $[n=8]$, angioten$\sin$ II receptor blockers [ $\mathrm{n}=1]$, or calcium antagonists [ $\mathrm{n}=10]$ ) were equally distribured uver the different genotypes and patients with or without right ventricular hypertrophy.

\section{Electrocardiographic Evidence of Right Ventricular Hypertrophy}

Thirty-one patients (36\%) of the entire study group of 87 patients had electrocardiographic evidence of right ventricular hypertrophy. Fourteen patients $(16 \%)$ showed two criteria, nine patients $(10 \%)$ showed three criteria, five patients $(6 \%)$ showed four criteria, and three patients (4\%) showed five criteria of right ventricular hypertrophy.

Frequencies of RAS Genotypes in the Study Group

The distribution of the DD, ID, and II genotypes of the angiotensin converting enzyme gene was 32,49 , and $19 \%$, respectively. The distribution of the AA, AC, and CC genotypes of the angiotensin type 1 receptor gene was 53,37 , and $10 \%$ respectively, and the distribution of the MM, MT, and TT genotypes of the angiotensinogen gene was 33,49 , and $18 \%$ respectively.

Frequencies of RAS Genotypes in the Control Group

The distribution of the DD, ID, and II genotypes of the angiotensin converting enzyme gene was 29,53 , and $18 \%$. The distribution of the $A A, A C$, and CC genotypes of the angiotensin type 1 receptor gene was 42,49 , and $9 \%$ respectively, and the distribution of the MM, MT, and TT genotypes of the angiotensinogen gene was 33,48 , and $19 \%$ respectively. These percentages did not significantly differ from patients with COPD ( $p=0.96,0.33$, and 0.97 , respectively).

Separate analysis of frequencies of RAS genotypes in male and female subgroups in the study group and the control group did nor significantly differ either (data not shown). 
Table 1. - Association between right ventricular hypertrophy and the ACE DD or non-DD genotype.

\begin{tabular}{|c|c|c|c|c|c|c|}
\hline \multirow[t]{2}{*}{ ACE GENOTYPE } & \multicolumn{2}{|l|}{ RVH } & \multirow[t]{2}{*}{$x^{2}$} & \multirow[t]{2}{*}{$p$} & \multirow[t]{2}{*}{ Odds ratio } & \multirow[t]{2}{*}{$95 \% \mathrm{CI}$} \\
\hline & Yes $(\%)$ & No $(\%)$ & & & & \\
\hline \multicolumn{7}{|l|}{ All patients $(n=87)$} \\
\hline$D D(n=27)$ & 22.2 & 77.8 & 3.0 & 0.08 & 1.8 & $0.8-4.0$ \\
\hline non DD (ID, II) $(n=60)$ & 41.7 & 58.3 & & & & \\
\hline \multicolumn{7}{|l|}{ Male patients $(n=62)$} \\
\hline$D D(n=19)$ & 21.1 & 78.9 & 3.8 & 0.05 & 2.2 & $0.8-5.5$ \\
\hline non DD (ID, II) $(n-43)$ & 46.5 & 53.5 & & & & \\
\hline \multicolumn{7}{|l|}{ Female patients $(n=25)$} \\
\hline DD $(n=8)$ & 25 & 75 & 0.05 & 0.82 & 1.1 & $0.2-4.8$ \\
\hline non $D D(n=17)$ & 29.4 & 70.6 & & & & \\
\hline
\end{tabular}

Definition of abbreviations: $n=$ number of patients; $A C E=$ angiotensin converting enzyme; $R V H=$ right ventricular hypertrophy; $\mathrm{CI}=$ confidence interval.

Associations between the ACE genotypes and right ventricular hypertrophy

In the male subgroup, the ACE DD genotype was negatively associated with electrocardiographic evidence of right ventricular hypertrophy $\left(\chi^{2}=3.8\right.$; odds ratio, 2.2; $95 \%$ confidence interval, 0.8 to $5.5 ; \mathrm{p}=0.05$ ) (Table 1 ). In the female subgroup there was no such association $\left(\chi^{2}=0.05\right.$; odds ratio, $1.1 ; 95 \%$ confidence interval, 0.2 to $4.8 ; \mathrm{p}=0.82$ ). There was no association berween the presence of the $\mathrm{D}$ allele (DD and ID) and the presence or absence of electrocardiographic evidence of right ventricular hypertrophy (entire study group: $\chi^{2}=0.56, p=0.45$; male: $\chi^{2}=0.38, p=0.53$; fem:le: $\chi^{2}=0.05, p=0.82$ ).

Possible Confounding Variables in ACE I/D Genotype Subgroups

Mean $\mathrm{PaCO}_{2}, \mathrm{~Pa}_{2}$ and $\mathrm{Sa}_{2}$ were comparable between the different subgroups (for instance, $\mathrm{DD}$ versus non-DD: $\mathrm{PaCO}_{\mathrm{C}}=5.6$ and $5.7 \mathrm{kPa}$, respectively, $\mathrm{Pa}_{\mathrm{C} / 2}=9.1$ and $9.3 \mathrm{kPa}$, respectively, (Table 2). Patients (male and female) with the DD genotype had a significant higher $\mathrm{Ht}$ than did parients with the non-DD genotype (mean, 44.7 and $42.7 \%$, respectively, $t=-2.9, \mathrm{p}=0.004)$. This was also true in the male subgroup with the DD genotype (mean, 45.1 and $42.9 \%$, respectively, $t=-2.6, \mathrm{P}=0.01$ ). $\mathrm{Pa}$ tients with the $\mathrm{D}$ allele (DD and ID) were significantly younger than the patients with the II genotype (mean, 64.7 and $67.8 \mathrm{yr}$, respectively, $\mathrm{t}=1.9, \mathrm{p}=0.05$ ) and had a sig- 


\begin{tabular}{|c|c|c|c|c|c|c|}
\hline & \multicolumn{2}{|c|}{ Male and female } & \multicolumn{2}{|l|}{ Male } & \multicolumn{2}{|l|}{ Female } \\
\hline & DD & non-DD & DD & non-DD & DD & non-DD \\
\hline Age (yr) & $64.1 \pm 6.6$ & $65.9 \pm 7.3$ & $64.6 \pm 7.7$ & $66.6 \pm 7.1$ & $62.8 \pm 3.0$ & $64.1 \pm 7.6$ \\
\hline $\mathrm{FEV}_{1}$ (\%pred) & $38.2 \pm 12.7$ & $36.8 \pm 12.2$ & $36.2 \pm 10.5$ & $35.2 \pm 12.6$ & $43.7 \pm 17.0$ & $40.7 \pm 10.7$ \\
\hline $\mathrm{PacO}_{\mathrm{CO}}(\mathrm{kPa})$ & $5.6 \pm 0.7$ & $5.7 \pm 0.8$ & $5.5 \pm 0.7$ & $5.8 \pm 0.9$ & $5.7 \pm 0.8$ & $5.5 \pm 0.7$ \\
\hline $\mathrm{Pa}_{02}(\mathrm{kPa})$ & $9.1 \pm 1.3$ & $9.3 \pm 1.2$ & $9.2 \pm 1.1$ & $9.3 \pm 1.1$ & $8.8 \pm 1.7$ & $9.3 \pm 1.4$ \\
\hline $\mathrm{Sa}_{02}(\%)$ & $93.2 \pm 3.1$ & $93.4 \pm 2.8$ & $93.5 \pm 2.2$ & $93.4 \pm 2.8$ & $92.3 \pm 5.2$ & $93.2 \pm 2.9$ \\
\hline$H \mathrm{t}(\%)$ & $44.7 \pm 2.6$ & $42.7 \pm 3.4 \dagger$ & $45.1 \pm 2.8$ & $42.9 \pm 3.4 \ddagger$ & $43.8 \pm 2.2$ & $42.1 \pm 3.7$ \\
\hline
\end{tabular}

nificantly higher $\mathrm{FEV}_{1}$ (\% pred) than did patients with the II genotype (mean, 38.5 and $31.7 \%$, respectively, $t=-2.2, p=0.03$ ).
Associations between the $\mathrm{AGT}_{1} \mathrm{R}$ and AGT Genotypes and Right Ventricular Hypertrophy

We found no significant associations between the investigated polymorphisms in the $A G T_{1} R$ and $A G T$ genes and electrocardiographic evidence of right ventricular hypertrophy, neither for the group as a whole nor for female and male subgroups.

Possible Confounding Variables in $\mathrm{AGT}_{1} \mathrm{R}$ and AGT Genotype Subgroups

Mean $\mathrm{PaCO}_{2} \mathrm{~Pa}_{\mathrm{O} 2}$ and $\mathrm{FEV}_{1}$ (\% pred) were comparable between the different subgroups (data not shown). Male patients with the $\mathrm{AGT}_{1} \mathrm{RC}$ allele (CC and $\mathrm{AC}$ ) had a significantly lower $\mathrm{SaO}_{2}$ and were significantly older than the patients with the $\mathrm{AGT}_{1} \mathrm{R}_{\mathrm{AA}}$ genotype (mean $\mathrm{Sa}_{\mathrm{O} 2} 92.7$ and $94.1 \%$, respectively, $\mathrm{t}=2.0, \mathrm{p}=0.04$ and mean age, 68 and $64 \mathrm{yr}$, respecrively, $\mathrm{t}=-2.1, \mathrm{p}=0.03$ ). This was also true for the mean age in the entire group (mean age, 67 and $64 \mathrm{yr}$, respectively, $\mathrm{t}=-1.9, \mathrm{p}=0.05$ ).

\section{DISCUSSION}

The main finding of this study was a negative association between the ACE DD genotype and electrocardiographic evidence of right ventricular hypertrophy in male patients with COPD. This negative association was in contrast with our hypothesis that stated that the ACE DD genotype would be positively associated with right ventricu- 
lar hypertrophy. This hypothesis was based on recent findings of Abraham and colleagues (21) in patients with pulmonary hypertension that indeed showed more extensive adaptive right ventricular hypertrophy. An important difference, however, between those data and our study is that Abraham and coworkers studied parients with primary pulmonary hypertension, whereas we studied patients with COPD who may develop pulmonary hypertension secondary to chronic alveolar hypoxia. The different outcome of the two studies may suggest that the function of the renin angiotensin system differs in primary pulmonary hypertension from that in secondary pulmonary hypertension in COPD. A differential function of the renin angiotensin system was also observed in two different animal models of pulmonary hypertension (7).

Because we realize that the prevalence of right ventricular hypertrophy in patients with COPD increases not only with the severity of airway obstruction but also with several other factors such as age, hypoxemia, $\mathrm{CO}_{2}$ retention, and polycythemia $(29,30)$, we analyzed the effects of these possible confounding variables on the associations between ACE genotypes and electrocardiographic evidence of right ventricular hypertrophy. The mean $\mathrm{PaCO}_{2}, \mathrm{PaO}_{2}, \mathrm{FEV}_{1}$ (\% pred), $\mathrm{Sa}_{2}$, and age were nor significantly different in patients with the $\mathrm{DD}$ genotype from those in patients with the non-DD genotype. However, the mean $\mathrm{Ht}$ was significantly higher in both the patient group as a whole and in the male subgroup with the DD genotype compared with the non-DD genotype patients (mean, 44.7 and $42.7 \%$; mean, 45.1 and $42.9 \%$, respectively). The higher hematocrit reported for the whole patient group with a DD genotype versus patients with the non-DD genotype may be explained by the higher hematocrit in the male subgroup. Although these mean $\mathrm{Ht}$ values are within normal limits and the mean differences are small, the increased $\mathrm{Ht}$ could potentially contribute to increased pulmonary arterial pressures in patients with COPD with the DD genotype. However, an increased $\mathrm{Ht}$ would be associated with an increased right ventricular hypertrophy. Because we found a negative association between the ACE DD genotype and right ventricular hypertrophy, normalization of the data for $\mathrm{Ht}$ would result in an even stronger negative association between the ACE DD genotype and right ventricular hypertrophy.

The ACE DD genotype was negatively associared with right ventricular hypertophy, but only in the male patients. Interestingly, the ACE DD genotype was recencly found to be a sex-specific candidate gene for systemic hypertension (31), albeit that in that study the ACE DD genotype was positively associated with systemic hypertension.

In female patients no association was found between the DD genotype and electrocardiographic evidence of right ventricular hypertrophy. It is well known that the female sex is a cardioprotective factor, and there is a growing body of evidence that estrogens modulate the development of cardiac hypertrophy (32). Estradiol protects against pulmonary vascular remodeling and right ventricular hypertrophy in male monocrotaline treated rats (33). Finally, estradiol treatment has been shown to attenuate hypoxia-induced vasoconstriction in lamb lungs (34). We therefore believe that, although most female patients in this study were postmenopausal, estrogens may 
mask or delay a potential association between the ACE genotype and right ventricular hypertrophy in female patients with COPD.

Patients carrying the $\mathrm{D}$ allele (DD and ID) were significantly younger and had a significantly higher $\mathrm{FEV}_{1}$ (\% pred) than did patients with the II genotype. Younger age and a higher $\mathrm{FEV}_{1}$ (\% pred) could theoretically mean less right ventricular hypertrophy compared with older patients and patients with a lower $\mathrm{FEV}_{1}$ (\% pred). In the present study, however, there was no association between the presence of the D allele (DD and ID genotype) and the presence or absence of electrocardiographic evidence of right ventricular hypertrophy.

No significant associations were found between the angiotensin II type 1 receptor $\left(A^{1166} \mathrm{C}\right)$ and angiotensinogen $\left(\mathrm{M}^{235} \mathrm{~T}\right)$ genotypes and electrocardiographic evidence of right ventricular hypertrophy. In the systemic circulation, the angiotensin II type 1 receptor CC genotype and especially the angiotensinogen TT genotype have been associated with essential hypertension $(18,19)$. The data presented here suggest that these polymorphisms do not significantly contribute to the development of pulmonary hypertension and/or right ventricular hypertrophy in patients with COPD.

In theory, the distribution of RAS genotypes may be different in patients with COPD from that in patients without COPD. However, the distributions of the ACE, $A G T_{1} R$, and $A G T$ genotypes found in the present study did not significantly differ from those in our control group and those described in control populations of other studies $(12,17,20)$. It is therefore unlikely that the negative association between the DD genotype of the ACE gene and electrocardiographic parameters of right ventricular hypertrophy is influenced by differences in ACE genotype distribution in patients with and without COPD. The mean age of the control group was $50 \mathrm{yr}(\mathrm{SD}, 7)$, which is indeed lower than the mean age of the COPD group $(65 \mathrm{yr} ; \mathrm{SD},=7)$. To exclude a possible pre-COPD confounder in the control group we have subanalyzed the data of the control group. Analysis of the RAS genorypes in the older subjects in the control group (mean age, $58 \mathrm{yr} ; \mathrm{SD}, 5 ; \mathrm{n}=27$ ) did not reveal a significant change in genotype distribution, not when compared with the young subgroup (mean age, $45 \mathrm{yr} ; \mathrm{SD}, 3 ; \mathrm{n}=$ $68 ; \mathrm{FEV}_{1} \%$ pred $\left.=94 \% ; \mathrm{SD}, 7\right)$, or when compared with the COPD group. Moreover, mean $\mathrm{FEV}_{1} \%$ pred in that older subgroup of our control population was $90 \%(\mathrm{SD}, 8)$, which is not significantly different from the $93 \%(S D, 8)$ of the total group, and far above that in the COPD group (37\%). Therefore, we think that it is very unlikely that our control group contained a COPD-prone subpopulation.

A limitation of the present study was that evidence of right ventricular hypertrophy was based on electrocardiographic criteria. Although electrocardiography is highly specific for detecting right ventricular hypertrophy in patients with COPD, this technique is rather insensitive (35).

In conclusion, this study has shown a negative association between the ACE DD genorype and electrocardiographic evidence of right ventricular hypertrophy in male patients with COPD. This may indicate that male patients with COPD with the ACE $\mathrm{DD}$ genorype have lower mean pulmonary arterial pressures and in theory have a better 
prognosis than do male patients with the non-DD genotype. On the other hand it could mean that male patients with COPD with the ACE DD genotype show less adaptive right ventricular hypertrophy, which theoretically could mean a worse prognosis when compared with male patients with the non-DD genotype. Further studies that include hemodynamic and echocardiographic measurements are needed to elucidate whether this negative association is a result of lower mean pulmonary arterial pressures or diminished adaptive right ventricular hypertrophy in these patients. Analysis of polymorphisms of the ACE gene may, in the future, play an important role in the risk assessment and medical management of pulmonary hypertension in male patients with COPD.

\section{REFERENCES}

1. Semmens $M$, Reid L. Pulmonary arterial muscularity and right ventricular hypertrophy in chronic bronchitis and emphysema. Br. J. Dis. Chest. 1974;68:253-263.

2. Morrell NW, Atochina EN, Morris KG, Danilov SM, Stenmark KR. Angiotensin converting enzyme expression is increased in small pulmonary arteries of rats with hypoxia-induced pulmonary hypertension. J. Clin. Invest. 1995;96:1823-1833.

3. Morrell NW, Danilov SM, Satyan KB, Morris KG, Stenmark KR. Right ventricular angiotensin converting enzyme activity and expression is increased during hypoxic pulmonary hypertension. Cardiovasc. Res. 1997;34:393-403.

4. Morrell NW, Morris KG, Stenmark KR. Role of angiotensin-converting enzyme and angiotensin II in development of hypoxic pulmonary hypertension. Am. J. Physiol. 1995;269:H1186-H1194.

5. Zhao L, Al-Tubuly R, Owji AA, Nunez DJR, Wilkins MR. Angiotensin II receptor expression and inhibition in the chronically hypoxic rat lung. Br. J. Pharmacol. 1996;119:1217-1222.

6. Nong Z, Stassen J-M, Moons L, Collen D, Janssens S. Inhibition of tissue angiotensinconverting enzyme with quinapril reduces hypoxic pulmonary hypertension and pulmonary vascular remodeling. Circulation 1996:94:1941-1947.

7. van-Suylen RJ, Smirs JFM, Daemen MJAP. Pulmonary artery remodeling differs in hypoxia- and monocrotaline induced pulmonary hypertension. Am. J. Respir. Crit. Care Med. 1998;157:1423-1428.

8. Farber MO, KiblawiSS, Strawbridge RA, Robertson GL, Weinberger MH, Manfredi F. Studies on plasma vasopressin and the renin-angiotensin-aldosterone system in chronic obstructive lung disease. J. Lab. Clin. Med. 1977;90:373-380.

9. Ucar G, Yildirim Z, Ataol E, Erdogan Y, Biber C. Serum angiotensin converting enzyme activity in pulmonary diseases: correlation with lung function parameters. Life Sci. 1997;61:1075-1082. 
10. Rigat B, Hubert C, Alhenc-Gelas F, Cambien F, Corvol P, Soubrier F. An insertion/deletion polymorphism in the angiotensin I-converting enzyme gene accounting for half the variance of serum enzyme levels. J. Clin. Invest. 1990;86:1343-1346.

11. Busjahn A, Knoblauch H, Knoblauch M, Bohlender J, Menz M, Faulhaber HD.. Becker A, Schuster H, Luft FC. Angiotensin-converting enzyme and angiotensinogen gene polymorphisms, plasma levels, cardiac dimensions. A twin study. Hypertension 1997;29:165-170.

12. Cambien F, Poirier O, Lecerf L, Evans A, Cambou JP, Arveiler D, Luc G, Bard JM, Bara L, Ricard S, Tiret L, Amouyel P, Alhenc-Gelas F, Soubrier F. Deletion polymorphism in the gene for angiotensin-converting enzyme is a potent risk factor for myocardial infarction. Nature 1992;359:641-644.

13. Raynolds MV, Bristow MR. Bush EW, Abraham WT, Lowes BD, Zisman LS, Taft CS, Perryman MB. Angiotensin-converting enzyme DD genotype in patients with ischaemic or idiopathic dilated cardiomyopathy. Lancet 1993;342:1073-1075.

14. Nakai K, Itoh C, Miura Y, Hotta K, Musha T, Itoh T, Miyakawa T, Iwasaki R, Hiramori $\mathrm{K}$. Deletion polymorphism of the angiotensin I-converting enzyme gene is associated with serum $A C E$ concentration and increased risk for CAD in the Japanese. Circulation 1994;90:2199-2202.

15. Schunkert H, Hense HW, Holmer SR, Stender M, Perz S, Keil U, Lorell BH, Riegger GA. Association between a deletion polymorphism of the angiotensin-convertingenzyme gene and left ventricular hypertrophy. N. Engl.J. Med. 1994;330:1634-1638.

16. Jeunemaitre X, Soubrier F, Kotelevtsev YV, Lifton RP, Williams CS, Charru A, Hunt SC, Hopkins PN, Williams RR, Lalouel JM, Corvol P. Molecular basis of human hypertension: role of angiotensinogen. Cell 1992;71:169-180.

17. Tiret L, Bonnardeaux A, Poirier O, Ricard S, Marques-Vidal P, Evans A, Arveiler D, Luc G, Kee F, Ducimetiere P, Soubrier F, Cambien F. Synergistic effects of angiotensinconverting enzyme and angiotensin-II type 1 receptor gene polymorphisms on risk of myocardial infarction. Lancet 1994;344:910-913.

18. Bonnardeaux A, Davies E, JeunemaitreX, Fery I, Charru A, Clauser E, Tiret L, Cambien F, Corvol P, Soubrier F. Angiotensin II type 1 receptor gene polymorphisms in human essential hypertension. Hypertension 1994;24:63-69.

19. Caulfield M, Lavender P, Farrall M, Munroe P, Lawson M, Turner P, Clark AJ. Linkage of the angiotensinogen gene to essential hypertension. $N$. Engl. J. Med.1994:330:1629-1633.

20. Katsuya T, Koike G, Yee TW, Sharpe N, Jackson R, Norton R, Horiuchi M, Pratt RE, Dzau VJ, MacMahon S. Association of angiotensinogen gene T235 variant with increased risk of coronary heart disease. Lancet 1995;345:1600-1603.

21. Abraham WT, Raynolds MV, Gottschall B, Badesch DB, Wynne KM, Groves BM, Lowes BD, Bristow MR, Perryman MB, Voelkel NF. Importance of angiotensinconverting enzyme in pulmonary hypertension. Cardiology 1995;86 Suppl 1:9-15.

22. ATS Statement. Standards for the diagnosis and care of patients with chronic obstructive pulmonary disease. Am. J. Respir. Crit. Care Med. 1995;152:S77-S120. 
23. Quanjer PH, Tammeling GJ, Cotes JE, Pedersen OF, Peslin R, Yernault JC. Lung volumes and forced ventilatory flows. Report Working Party Standardization of Lung Function Tests, European Community for Steel and Coal. Official Statement of the European Respiratory Society. Eur. Respir. J. Suppl. 1993;16:5-40.

24. Sreeram N, Cheriex EC, Smeets JL, Gorgels AP, Wellens HJ. Value of the 12-lead electrocardiogram at hospital admission in the diagnosis of pulmonary embolism. Am. J. Cardiol. 1994;73:298-303.

25. Rigat B, Hubert C, Corvol P, Soubrier F. PCR detection of the insertion/deletion polymorphism of the human angiotensin converting enzyme gene (DC.P1) (dipepridyl carboxypeptidase 1). Nucleic Acids Res. 1992;20:1433.

26. Shanmugam V, Sell KW, Saha BK. Mistyping ACE heterozygotes. PCR Methods Appl. 1993;3:120-121.

27. Russ AP, Maerz W, Ruzicka V, Stein U, Gross W. Rapid detection of the hypertensionassociated Met235 $\rightarrow$ Thr allele of the human angiorensinogen gene. Hum. Mol. Genet. 1993;2:609-610.

28. Wallenstein S, Zucker CL, Fleiss JL. Some statistical merhods useful in circulation research. Circ. Res. 1980;47:1-9.

29. Mirchell RS, Webb NC, Filley GF. Chronic obstructive pulmonary disease III. Factors influencing prognosis. Am. Rev. Respir. Dis. 1964;89:878-896.

30. Renzetti AD, McClement JH, Litr BD. The veterans administration cooperative study of pulmonary function. Am. J. Med. 1966;41:115-129.

31. O'Donnell CJ, Lindpaintner K, Larson MG, Rao VS, Ordovas JM, Schaefer EJ, Myers $\mathrm{RH}$, Levy $\mathrm{D}$. Evidence for association and genetic linkage of the angiotensin-converting enzyme locus with hypertension and blood pressure in men but not women in the Framingham Heart Srudy. Circulation 1998;97:1766-1772.

32. Grohe C, Kahlert S, Lobbert K, Meyer R, Linz KW, Karas RH, Vetter H. Modulation of hypertensive heart disease by estrogen. Steroids 1996;61:201-204.

33. Farhat MY, Chen MF, Bhatti T, Iqbal A, Cathapermal S, Ramwell PW. Protection by oestradiol against the development of cardiovascular changes associated with monocrotaline pulmonary hypertension in rats. Br. J. Pharmacol. 1993;110:719-723.

34. Gordon JB, Wetzel RC, McGeady ML, Adkinson Jr. NF, Sylvester JT. Effects of indomethacin on estradiol-induced atrenuation of hypoxic vasoconstriction in lamb lungs. J. Appl. Physiol. 1986;61:2116-2121.

35. MacNee W. Pathophysiology of cor pulmonale in chronic obstructive pulmonary disease. Part One. Am. J. Respir. Crit. Care Med. 1994;150:833-852. 


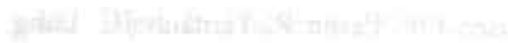

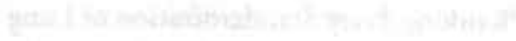

thit

- 
CHAPTER 6

Endothelial nitric oxide synthase gene polymorphisms and right ventricular hypertrophy in patients with chronic obstructive pulmonary disease 


\section{SUMMARY}

Nitric oxide (N0) contributes to the maintenance of low pulmonary vascular tone in healthy humans and there is evidence to suggest that changes in NO production play a role in the pathogenesis of pulmonary hypertension in patients with chronic obstructive pulmonary disease (COPD). The G894T polymorphism in exon 7 of the eNOS gene has been reported to be a strong risk factor for coronary spasm, acute myocardial infarction and essential hypertension, whereas the 27-bp repeat polymorphism in intron 4 of the endothelial nitric oxide synthase (eNOS) gene contributes to the variance of basal NO production. There are, however, no reports on an association between the above mentioned polymorphisms of the eNOS gene and right ventricular hypertrophy in patients with COPD. We correlated electrocardiographic parameters of right ventricular hypertrophy with these two polymorphisms of the eNOS gene in 86 patients with severe stable COPD. $35 \%$ of these patients showed electrocardiographic evidence of right ventricular hypertrophy. No association was found between the investigated polymorphisms of the eNOS gene and electrocardiographic evidence of right ventricular hypertrophy in patients with severe stable COPD. In the present study we found no association between the eNOS T or a alleles and electrocardiographic evidence of right ventricular hypertrophy in patients with severe stable COPD. 


\section{INTRODUCTION}

Nitric oxide (NO) is a potent vasodilator and contributes to the maintenance of low pulmonary vascular tone in healthy individuals (1-3). NO is synthesized from L-arginine by nitric oxide synthase (NOS). Three isoforms of NOS have been identified: the neuronal constitutive nitric oxide synthase (nNOS), the inducible nitric oxide synthase (iNOS) and the endothelial constitutive nitric oxide synthase (eNOS), which is expressed in normal pulmonary endothelial cells. A reduction in basal NO release may predispose to the development of pulmonary hypertension and there is increasing evidence to suggest that alterations of eNOS expression in the lung may play a role in the pathogenesis of hypoxia induced pulmonary hypertension as occurs in patients with COPD. Indeed several authors have reported that endothelium-dependent relaxation is impaired in pulmonary arteries of patients with COPD $(4,5)$. The data on the expression of the eNOS gene are however less clear. Both decreased (6) and increased (7) expression of eNOS have been reported in patients with primary and secondary pulmonary hypertension. Also experimental studies have yielded some contradictory data with respect to NOS mRNA expression under hypoxic conditions. Hypoxia decreases the expression of eNOS mRNA in human pulmonary endothelial cells (8), whereas increased expressions of $\mathrm{nNOS}$, eNOS and iNOS mRNA's have been reported in the rat lung under hypoxic conditions (9-11). In mice with a congenital deficiency in the eNOS gene hypoxic pulmonary vascular remodeling, pulmonary hypertension and right ventricular hypertrophy is enhanced as compared with wild-type animals (12). These latter data suggest that the production of NO by eNOS may provide a counterbalance against hypoxia induced pulmonary vasoconstriction.

There are several possibilities to explain the contradictory data with respect to eNOS expression and pulmonary hypertension. One of those is the effect of the guanine $(\mathrm{G})$ to thymine $(\mathrm{T})$ substitution polymorphism of the eNOS gene (G894T) within exon 7 resulting in a replacement of glutamic acid by asparric acid at codon 298 (Glu298Asp). The functional consequences of this $\mathrm{G}$ to $\mathrm{T}$ substitution are not known yet, but the missense Glu298Asp variant has been reported to be a strong risk factor for coronary spasm, acute myocardial infarction and essential hypertension (13-16). A 27 -bp repeat polymorphism is another variant of the eNOS gene. A recent study in healthy individuals indicates that the 27-bp repeat polymorphism of the eNOS gene contributes to the variance of basal NO production (17). The gene encoding eNOS is located on chromosome $7 q 35-36$. In the fourth intron two alleles have been identified that differ by one 27 base pair repeat. The eNOS a allele has four repeats and the eNOS $\mathrm{b}$ allele has five repeats. For both polymorphisms no data are available for a possible. association with right ventricular hypertrophy in patients with COPD. With respect to the $\mathrm{NOS} \mathrm{G} / \mathrm{T}$ polymorphism we hypothesized that, in analogy with data derived from the systemic circulation, the $\mathrm{eNOS} \mathrm{T}$ allele in patients with COPD is positively associated with right ventricular hypertrophy. With respect to the $\mathrm{NOS} \mathrm{a} / \mathrm{b}$ polymorphism 
the hypothesis was that in patients with COPD, the eNOS a allele is beneficial, because the higher level of basal $\mathrm{NO}$ production in these patients may counterbalance the hypoxia induced pulmonary vasoconstriction. This would mean that patients with COPD and the eNOS a allele have lower pulmonary artery pressures compared with the eNOS bb genorype and as a consequence show less adaptive right ventricular hypertrophy. Since there are no data available with respect to a potential association of the G/T and a/b polymorphisms of the eNOS gene and pulmonary hypertension associated right ventricular hypertrophy in patients with COPD we correlated electrocardiographic parameters of right ventricular hypertrophy with the distribution of eNOS GG, GT, TT, aa. ab and bb genotypes in patients with severe stable COPD.

\section{METHODS}

\section{Study Population}

Eighty-six patients with severe COPD were included in this study (61 male, 25 female) with a mean age of 65 years (range 46-79 years). Informed consent was obrained from all patients, and the research program was approved by the local ethical committee. All patients had COPD according to the criteria of the American Thoracic Society (18) and $\mathrm{FEV}_{1}$ expressed as a percentage of the reference values ( $\mathrm{FEV}_{1} \%$ pred) < $70 \%$ (19). Parients were admitted to the pulmonary rehabilitation centre Hornerheide (Horn, the Netherlands) and were stable at the time of the study. Patients with electrocardiographic evidence of severe left ventricular hypertrophy and/or myocardial infarction and patients with signs of left ventricular heart failure and/or heart murmers on physical examination were excluded.

\section{Control Group}

The control group consisted of 95 individuals ( 42 male, 53 female) without a clinical history of COPD. The mean $\mathrm{FEV}_{1} \%$ pred was $93 \%(\mathrm{SD}, 8)$. The mean age was 50 years (range $41-70 \mathrm{yr}$ ) These individuals were, as the study group, all Caucasians and living in the same region.

\section{Pulmonary Function and Blood Gas Studies}

FEV $_{1}$ was measured, using a pneumotachograph (Masterlab; Jaeger, Wurzburg, Germany) and expressed as a percentage of reference values ( $\mathrm{FEV}_{1} \%$ pred.). Blood was drawn by puncture of the radial artery while patients breathed room air. $\mathrm{Pa}_{2}, \mathrm{PaCO}_{2}$, and $S_{d_{1}(2)}$ were measured using a blood gas analyzer (ABL 330; Radiometer, Copenhagen, Denmark). 


\section{Electrocardiography}

A 12-lead electrocardiogram (ECG) was made to assess the presence of right ventricular hypertrophy. The following ECG criteria of right ventricular hypertrophy were used:

1. Incomplete or complete right bundle branch block. 2 . Right axis deviation, defined as a frontal plane QRS axis of $>90^{\circ}$. 3. P wave in lead V1, II or III of $>2.5 \mathrm{~mm}$ ( $P$ pulmonale). 4 . $S$ wave of $>1.5 \mathrm{~mm}$ in lead $\mathrm{I}$ in combination with a slow $\mathrm{R}$ progression. 5. Clockwise rotation of the heart in the horizontal axis defined as a shift in the transition zone to V5 or beyond. 6. Low voltage QRS complex of $<5 \mathrm{~mm}$ in all the limb leads ( II, III, and AVF).

The ECGs were evaluated by two cardiologists (PvP and EC) and in all patients agreement was reached. A positive ECG diagnosis suggestive for right ventricular hypertrophy was accepted if two or more ECG criteria were present (20).

\section{Genotyping of the G894T Polymorphism in Exon 7 of the eNOS Gene}

Genomic DNA from peripheral blood leukocytes was extracted with the QIAmp Blood Kit (QIAGEN Inc. Chatsworth, California, USA). We adopted the mutagenically separated PCR technique (21) to determine the genotype of the G894T mutation. Briefly, two allele-specific primers and their nonselective complementary strand primer were mixed and used for the PCR amplification in a single reaction. Deliberate differences were introduced into the allele-specific primers in addition to the base substitution, and they were able to drastically reduce cross-reactions between two allelic PCRs in a mixed reaction. The following primers were used: FP894T, 5'-AAACGGTCGCTTCGACGTGCACCCCCTGCTGCTGCAGGCCCCAGA TGGT-3'; FP894G， 5'-TGCCCCTGCTGCTGCAGGCCCCAGATTAG-3'; RP894, 5'-TGTGGGATCAGCACCCCCTTGCAGGCCC-3', in which deliberated differences and base substitutions are underlined. PCR was performed in a $25 \mu \mathrm{l}$ reaction volume containing $50 \mathrm{mmol} / \mathrm{L} \mathrm{KCl}, 10 \mathrm{mmol} / \mathrm{L}$ Tris- $\mathrm{HCl} \mathrm{pH} 8.3,2$ $\mathrm{mmol} / \mathrm{L}, \mathrm{MgCl}_{2}, 0.1 \mathrm{mmol} / \mathrm{L}$ each of the four dNTPs, $5 \mathrm{pmol}$ of primer FP894T, 10 pmol of primer FP894G, 10 pmol of primer RP894, and 1.25 U AmpliTaq ${ }^{\circledR}$ DNA Polymerase (Perkin Elmer Inc.). The initial denaturation for 5 minutes at $94^{\circ} \mathrm{C}$ was followed by $40 \mathrm{cycles}$, each of $94^{\circ} \mathrm{C}$ for 45 seconds, $64^{\circ} \mathrm{C}$ for 45 seconds, and $72^{\circ} \mathrm{C}$ for 45 seconds, and by a final extension at $72^{\circ} \mathrm{C}$ for 10 minutes. The size of PCR products was $180 \mathrm{bp}$ and $200 \mathrm{bp}$ for the $894 \mathrm{G}$ and $894 \mathrm{~T}$ alleles, respectively, which were resolved on a $3 \%$ agarose gel.

Genotyping of the 27-bp Repeat Polymorphism in Intron 4 of the eNOS Gene

DNA was extracted as described above. The $\mathrm{eNOS}$ a/b genotype was determined by the polymerase chain reaction (PCR) and subsequent gel electrophoresis of the PCR products according to the method described by Wang (22). 


\section{Statistical Analysis}

The Hardy-Weinberg equilibrium for the frequencies of the two eNOS genotypes and differences in genotype distributions between patients with COPD with and without electrocardiographic evidence of right ventricular hypertrophy were tested by the chi-square analysis $\left(\chi^{2}\right)$. Means of variables potentially related to the development of right ventricular hypertrophy were compared by a two-sample $t$ test. Statistical significance was defined at $p<0.05$ (23). The Statistical Package for Social Sciences (SPSS Inc., release 7.5, Chicago, IL) was used for statistical analyses.

\section{RESULTS}

Allele Frequencies

Allele frequencies in both control and patient populations were in Hardy-Weinberg equilibrium.

Pulmonary Function Test and Blood Gas Analysis and Hematocrit in Patients with COPD

The mean $H F V_{1}$ (\% pred) was $37 \%$ (range 16 to $70 \%$ ). The mean $\mathrm{PaCO}_{2}$ and $\mathrm{PaO}_{2}$ were $5.7 \mathrm{kPa}$ (range 4.1-8.7) and $9.3 \mathrm{kPa}$ (range 6.4-12.7) respectively. The mean $\mathrm{Sa}_{(1)}$ was $93.5 \%$ (range $80-98 \%$ ). The mean $\mathrm{Ht}$ was $43.3 \%$ (range $33-52 \%$ ).

\section{Medication}

Patients receiving antihypertensive drug treatment (ACE inhibitors [ $\mathrm{n}=8$ ], angioten$\sin$ II receptor blockers [ $n=1], r$ calcium antagonists $[n=10]$ ) were equally distributed over the different genotypes and patients with or without right ventricular hypertrophy.

\section{Electrocardiographic Evidence of Right Ventricular Hypertrophy}

Thirty patients (35\%) of the entire study group of 86 patients showed electrocardiographic evidence of right ventricular hypertrophy. Fourteen patients $(16.3 \%)$ showed two criteria, nine patients (10.5\%) showed three criteria, five patients $(5.8 \%)$ showed four criteria, and two parients (2.3\%) showed five criteria of right ventricular hypertrophy. 
Table 1. - Association between right ventricular hypertrophy and the eNOS $a / b$ and $G / T$ genotype.

\begin{tabular}{|c|c|c|c|c|c|c|}
\hline \multirow[t]{2}{*}{ ENOS GENOTYPE } & \multicolumn{2}{|l|}{ RVH } & \multirow[t]{2}{*}{$x^{2}$} & \multirow[t]{2}{*}{$P$} & \multirow[t]{2}{*}{ Odds ratio } & \multirow[t]{2}{*}{$95 \% \mathrm{CI}$} \\
\hline & Yes $(\%)$ & No $(\%)$ & & & & \\
\hline $\begin{array}{l}\text { eNOS a/b }(n-86) \\
\text { a allele }(a a, a b)(n=28) \\
\text { bb }(n=58)\end{array}$ & $\begin{array}{l}39.3 \\
33.3\end{array}$ & $\begin{array}{l}60.7 \\
66.7\end{array}$ & 0.29 & 0.5 & 0.8 & $0.4-1.5$ \\
\hline eNOS G/T $(n=86)$ & & & & & & \\
\hline $\begin{array}{l}\pi(n=5) \\
\text { non } \pi(N-81)\end{array}$ & $\begin{array}{l}20.0 \\
35.8\end{array}$ & $\begin{array}{l}80.0 \\
64.2\end{array}$ & 0.51 & 0.4 & 1.7 & $0.3-10.5$ \\
\hline $\begin{array}{l}T \text { allele }(\pi, G T)(n=47) \\
\text { GG }(n=39)\end{array}$ & $\begin{array}{l}36.2 \\
33.3\end{array}$ & $\begin{array}{l}63.8 \\
66.7\end{array}$ & 0.07 & 0.7 & 0.9 & $0.5-1.6$ \\
\hline
\end{tabular}

Definition of abbreviations: $n=$ number of patients; RVH = right ventricular hypertrophy; $\mathrm{CI}$ confidence interval.

Frequencies of eNOS G/T Genotypes in Patients with COPD and the Control Group

The genotype frequencies for eNOS GG, GT, and TT in patients with COPD were $45.3(n=39), 48.8(n=42)$ and $5.8 \%(n=5)$ respectively. In the control group the distribution of the GG, GT and TT genotypes of the eNOS gene was 48.4, 40.0, and $11.6 \%$. These percentages did not significantly differ from patients with $\operatorname{COPD}\left(\chi^{2}=\right.$ 2.5; $p=0.2$ ). The frequencies of eNOS G/T genotypes in the male and female subgroups of patients with COPD and the controls did not significantly differ either (dara not shown).

Associations Between the eNOS G/T Genotype and Right Ventricular Hypertrophy

There was no association between the presence of the $\mathrm{eNOS} T$ allele and the presence or absence of electrocardiographic evidence of right ventricular hypertrophy, neither in homozygous (TT) nor in homozygous and heterozygous group of patients (TT and GT) $\left(\chi^{2}=0.51 ; p=0.4\right.$ and $\chi^{2}=0.07 ; p=0.7$ respectively; Table 1$)$.

Possible Confounding Variables in the eNOS G/T Genotype Subgroups

Mean age, $\mathrm{FEV}_{1}$ (\% pred) $\mathrm{PaCO}_{2}, \mathrm{P}_{20}, \mathrm{Sa}_{2}$ and hematocrit were comparable between patients with COPD with the eNOS TT genotype compared with parients 
Table 2. - Mean values of possible confounding variables between the different genotypes of the eNOS gene.

$$
\text { a altele bb } \quad \pi \quad \text { non- } \pi \text { T allele GG }
$$

$\begin{array}{lrrrrrr}\text { Age }(\mathrm{yr}) & 65.5 \pm 6.7 & 65.2 \pm 7.5 & 66.4 \pm 9.7 & 65.2 \pm 7.0 & 65.6 \pm 7.3 & 64.8 \pm 7.0 \\ \mathrm{FEV}_{1}(\% \mathrm{pred}) & 36.9 \pm 12.8 & 37.4 \pm 12.3 & 41.4 \pm 8.1 & 36.9 \pm 12.5 & 38.3 \pm 12.9 & 35.8 \pm 11.5 \\ \mathrm{~Pa}_{\mathrm{CO} 2}(\mathrm{kPa}) & 5.8 \pm 0.9 & 5.6 \pm 0.7 & 5.3 \pm 0.6 & 5.6 \pm 0.8 & 5.6 \pm 0.8 & 5.6 \pm 0.8 \\ \mathrm{~Pa}_{02}(\mathrm{kPa}) & 9.5 \pm 1.0 & 9.2 \pm 1.2 & 8.1 \pm 0.8 & 9.3 \pm 1.2 & 9.2 \pm 1.2 & 9.4 \pm 1.2 \\ \mathrm{Sa}_{02}(\%) & 94.1 \pm 1.5 & 93.2 \pm 3.0 & 91.4 \pm 2.1 & 93.4 \pm 2.9 & 93.1 \pm 2.9 & 93.6 \pm 2.9 \\ \mathrm{Ht}(\%) & 43.0 \pm 2.8 & 43.5 \pm 3.6 & 42.0 \pm 5.7 & 43.4 \pm 3.2 & 43.7 \pm 3.9 & 42.8 \pm 2.5\end{array}$

Definition of abbreviation: $\mathrm{yr}$ - years; $\mathrm{Ht}$ - hematocrit. All values are means \pm SD.

with the non-TT genorype (GT and GG) and patients with the presence of the $T$ allele (TT and GT) compared with patients with the GG genotype (Table 2).

Frequencies of eNOS a/b Genotypes in Patients with COPD and in the Control Group

The genorype frequencies of eNOS aa, eNOS $a b$, and eNOS bb in patients with COPD were $1.2(n=1), 31.4(n=27)$, and $67.4 \%(n=58)$ respectively. In the control group the distribution of the $a \mathrm{a}, \mathrm{ab}$ and bb genotypes of the eNOS gene was 4.2, 28.4, and $67.4 \%$ respectively. These percentages did not significantly differ from patients with COPD $\left(\chi^{2}=1.6 ; p=0.43\right)$. The frequencies of $\mathrm{eNOS} \mathrm{a} / \mathrm{b}$ genorypes in the male and female subgroups of patients with COPD and the controls did nor significantly differ either (data not shown).

Associations Between the eNOS a/b Genotype and Right Ventricular Hypertrophy

Only one patient had the eNOS aa genotype. In the statistical analysis this patient was included in the patients group with the eNOS ab genorype (presence of an a allele). There was no association between the presence of the $\mathrm{eNOS}$ a allele and electrocardiographic evidence of right ventricular hypertrophy, neither in the group as a whole nor in the female and male subgroups (group as a whole: $\chi^{2}=0.29 ; \mathrm{p}=0.5$, female subgroup: $\chi^{2}=0.12 ; \mathrm{p}=0.7$, male subgroup: $\chi^{2}=0.22 ; \mathrm{p}=0.6$; Table 1 ).

Possible Confounding Variables in the eNOS a/b Genotype Subgroups

Mean age, $\mathrm{FEV}_{1}$ (\% pred) $\mathrm{Pa}_{\mathrm{CO}}, \mathrm{PaO}_{2}, \mathrm{SaO}_{2}$ and hematocrit were comparable between parients with COPD with the presence of the a allele (aa and ab genotype) compared with patients with the eNOS bb genotype (Table 2). 


\section{DISCUSSION}

In contrast with our hypothesis we found no association between the eNOS T or a alleles and electrocardiographic evidence of right ventricular hypertrophy in patients with severe COPD. There may be several explanations for the absence of an association between the investigated eNOS polymorphisms and electrocardiographic evidence of right ventricular hypertrophy. The most likely explanation is that the differences in basal NO production in patients with COPD with different $\mathrm{eNOS}$ genotypes, are too small to attenuate or to prevent chronic alveolar hypoxia induced pulmonary vasoconstriction and the development of pulmonary hypertension. This observation does not implicate that NO does not play a role in the pathogenesis of pulmonary hypertension and right ventricular hypertrophy in patients with COPD. The contribution of the investigated eNOS polymorphism to changes in basal NO production in these patients appears, however, to be of minor importance. Other polymorphisms of genes responsible for vasoactive substances like polymorphisms of the angiotensin converting enzyme gene may play a more crucial role in the development of right ventricular hypertrophy in patients with COPD. In fact we have recently shown, in the very same population as used in the present study, that the ACE DD genotype in male patients with COPD is negatively associared with electrocardiographic evidence of right ventricular hypertrophy (24).

Moreover, it may be that not in all patients with COPD, right ventricular hypertrophy was identified by means of electrocardiography. It is well known that electrucardiography is highly specific but rather insensitive for detecting right ventricular hypertrophy in patients with COPD (25). However, the earlier reported association between the ACE DD genotype and right ventricular hypertrophy in the same population makes this less likely (24).

The absence of an association between the eNOS G/T and a/b genotypes and right ventricular hypertrophy is not a result of differences in the distribution of these eNOS genotypes in patients with COPD compared with patients without COPD. The distributions of the eNOS G/T and a/b genotypes found in the present study did not significantly differ from our control group. To exclude a possible pre-COPI) confounder in the control group we have subanalyzed the data of the control group. Analysis of the eNOS genotypes in the older people in the control group (mean age 58 years; $\mathrm{SD}, 5 ; \mathrm{n}=27$ ) did not reveal a significant change in genotype distribution compared with the COPD group. Moreover, mean $\mathrm{FEV}_{1} \%$ pred in the older subgroup of our control population was $90 \%(\mathrm{SD}, 8)$, which is not significantly different from the $93 \%(\mathrm{SD}, 8)$ of the total group, and far above that in the COPD group (37\%). Therefore, we think that it is very unlikely that our control group contained a COPD-prone subpopulation.

In conclusion, in the present study we found no association between the eNOS $\mathrm{T}$ or a alleles and electrocardiographic evidence of right ventricular hypertrophy in patients with severe stable COPD. 


\section{REFERENCES}

1. Vallance $P$, Collier J, Moncada S. Effects of endothelium-derived nitric oxide on peripheral arteriolar tone in man. Lancet 1989;2:997-1000.

2. Stamler JS, Loh E, Roddy MA, Currie KE, Creager MA. Nitric oxide regulates basal systemic and pulmonary vascular resistance in healthy humans. Circulation 1994;89:2035-2040.

3. Celermajer DS, Dollery C, Burch M, Deanfield JE. Role of endorhelium in the maintenance of low pulmonary vascular tone in normal children. Circulation 1994;89:2041-2044.

4. Dinh-Xuan AT, Higenbottam TW, Clelland CA, Pepke-Zaba J, Cremona G, Butt AY, Large SR, Wells FC, Wallwork J. Impairment of endothelium-dependent pulmonaryartery relaxation in chronic obstructive lung disease. $N$. Engl. J. Med. 1991;324:1539-1547.

5. Peinado VI, Barbera JA, Ramirez J, Gomez FP, Roca J, Jover L, Gimferrer JM, Rodriguez-Roisin R. Endothelial dysfunction in pulmonary arteries of patients with mild COPD. Am. J. Physiol. 1998;274:L908-L913.

6. Giaid A, Saleh D. Reduced expression of endothelial nitric oxide synthase in the lungs of patients with pulmonary hypertension. N. Engl.J. Med. 1995;333:214-221.

7. Xue C, Johns RA. Endothelial nitric oxide synthase in the lungs of patients with pulmonary hypertension. N. Engl. J. Med.1995:333:1642-1644.

8. Ziesche R, Petkov V, Williams J, Zakeri SM, Mosgöller W, Knöfler M, Block LH. Lipopolysaccharide and interleukin 1 augment the effects of hypoxia and inflammation in human pulmonary arterial rissue. Proc. Natl. Acad. Sci. USA 1996;93:12478-12483.

9. Shaul PW, North AJ, Brannon TS, Ujiie K, Wells LB, Nisen PA, Lowenstein CJ, Snyder $S H, S t a r$ RA. Prolonged in vivo hypoxia enhances nitric oxide synthase type I and type III gene expression in adult rat lung. Am. J. Respir. Cell. Mol. Biol. 1995;13:167-174.

10. Le-Cras TD, Xue C, Rengasamy A, Johns RA. Chronic hypoxia upregulates endothelial and inducible NO synchase gene and protein expression in rat lung. Am. J. Physiol. 1996;270:L164-L170.

11. Xue C, Johns RA. Upregulation of nitric oxide synthase correlates temporally with onset of pulmonary vascular remodeling in the hypoxic rat. Hypertension 1996:28:743-753.

12. Steudel W, Scherrer-Crosbie M, Bloch KD, Weimann J. Huang PL, Jones RC, Picard MH, Zapol WM. Sustained pulmonary hypertension and right ventricular hyperrrophy after chronic hypoxia in mice with congenital deficiency of nitric oxide synthase 3.. Clin. Invest. 1998;101:2468-2477.

13. Yoshimura M, Yasue H, Nakayama M, Shimasaki Y, Sumida H, Sugiyama S, Kugiyama K, Ogawa H, Ogawa Y, Saito Y, Miyamoto Y, Nakao K. A missense Glu298Asp variant in the endothelial nitric oxide synthase gene is associated with coronary spasm in the Japanese. Hum. Genet. 1998;103:65-69.

14. Shimasaki Y, Yasue H, Yoshimura M, Nakayama M, Kugiyama K, Ogawa H, Harada E, Masuda T, Koyama W, Saito Y, Miyamoto Y, Ogawa Y, Nakao K. Associacion of the 
missense Glu298Asp variant of the endothelial nitric oxide synthase gene with myocardial infarction. J. Am. Coll. Cardiol.1998;31:1506-1510.

15. Hibi K, Ishigami T, Tamura K, Mizushima S, Nyui N, Fujita T, Ochiai H, Kosuge M, Watanabe Y, Yoshii Y, Kihara M, Kimura K, Ishii M, Umemura S. Endothelial nitric oxide synchase gene polymorphism and acute myocardial infarction. Hypertension 1998;32:521-526.

16. Miyamoto $Y$, Saito Y, Kajiyama N, Yoshimura M, Shimasaki Y, Nakayama M, Kamitani S, Harada M, Ishikawa M, Kuwahara K, Ogawa E, Hamanaka I, Takahashi N, Kaneshige T, Teraoka H, Akamizu T, Azuma N, Yoshimasa Y, Yoshimasa T, Itoh H, Masuda I, Yasue H, Nakao K. Endothelial nitric oxide synthase gene is positivcly associated with essential hypertension. Hypertension 1998;32:3-8.

17. Wang XL, Mahaney MC, Sim AS, Wang J, Wang J, Blangero J, Almasy L, Badcnhop $\mathrm{RB}$, Wilcken DE. Genetic contribution of the endothelial constiturive nitric oxide synthase gene to plasma nitric oxide levels. Arterioscler. Thromb. Vasc. Biol. 1997;17:3147-3153.

18. ATS Statement. Standards for the diagnosis and care of patients with chronic obstructive pulmonary disease. Am. J. Respir. Crit. Care Med. 1995;152:S77-\$120.

19. Quanjer PH, Tammeling GJ, Cotes JE, Pedersen OF, Peslin R, Yernault JC. Lung volumes and forced ventilatory flows. Report Working Party Standardization of Lung Function Tests, European Community for Steel and Coal. Official Statement of the European Respiratory Society. Eur. Respir. J. Suppl 1993;16:5-40.

20. Sreeram N, Cheriex EC, Smeets JL, Gorgels AP, Wellens HJ. Value of the 12-lead electrocardiogram at hospital admission in the diagnosis of pulmonary embolism. Am. J. Cardiol. 1994;73:298-303.

21. Rust S, Funke H, Assmann G. Mutagenically separated PCR (MS-PCR): a highly specific one step procedure for easy mutation detection. Nucleic. Acids Res. 1993;21:3623-3629.

22. Wang XI, Sim AS, Badenhop RF, McCredie RM, Wilcken DE. A smoking-dependent risk of coronary artery disease associated with a polymorphism of the endothelial nitric oxide synthase gene. Nat. Med. 1996;2:41-45.

23. Altman DG, Gore SM, Gardner MJ, Pocock SJ. Statistical guidelines for contributors to medical journals. Br Med. J. 1983;286:1489-1493.

24. van-Suylen RJ, Wouters EF, Pennings HJ, Cheriex EC, van-Pol PE, Ambergen AW, Vermelis $A$, Daemen MJ. The DD genotype of the angiotensin converting enzyme gene is negatively associated with right ventricular hypertrophy in male patients with chronic obstructive pulmonary disease. Am. J. Respir. Crit. Care Med. 1999;159:1791-1795.

25. MacNee W. Pathophysiology of cor pulmonale in chronic obstructive pulmonary disease. Part One. Am. J. Respir Crit. Care Med 1994;150:833-852. 


\section{General discussion}

\subsection{INTRODUCTION}

In this thesis we have studied mediators that control the growth of pulmonary vascular smooth muscle cells in the development of pulmonary vascular remodeling in pulmonary hypertension.

First, we explored the role of AII in pulmonary vascular remodeling in the animal models. We consistently found that AII plays an important role in pulmonary vascular remodeling, but not in the development of right ventricular hypertrophy secondary to hypoxia induced pulmonary hypertension.

We extended the studies on involvement of the renin angiotensin system as well as nitric oxide by investigating whether polymorphisms of the RAS and eNOS contribute to the development of pulmonary hypertension and right ventricular hypertrophy in patients with severe COPD. We demonstrated that the ACE DD genorype is negatively associated with electrocardiographic evidence of right ventricular hypertrophy in male patients with COPD.

Furthermore the data show that there is limited correlation between structural pulmonary arterial changes and hemodynamic parameters, even if one optimizes the measurement of pulmonary vascular remodeling.

\subsection{PULMONARY ARTERY STRUCTURE AND FUNCTION}

Two techniques most commonly used to determine operability in children with congenital heart disease are hemodynamic evaluation by cardiac catheterization and histological evaluation of structural pulmonary arterial changes in open lung biopsies. There is, however, a great need for an optimal assessment of structural pulmonary vascular changes and the functional consequences of this remodeling process, since important discrepancies have been reported between structural pulmonary vascular changes and hemodynamic parameters and clinical outcome in individual patients with congenital heart disease (1-4). Our data, described in chapter 2, also show that in children with congenital heart disease medial thickening of muscular pulmonary arteries and muscularization of arterioles weakly correlate with pulmonary artery pressures. Moreover, there was no correlation between preoperative hemodynamic parameters and the presence of advanced plexogenic arteriopathy. 
One explanation for the apparent lack of a structure-function relation could be the fact that histological evaluation of structural pulmonary vascular changes was performed using inadequate parameters of structural pulmonary artery changes. In most studies evaluation of structural pulmonary vascular changes in children with congenital heart disease is performed using the grading system described by Heath and Edwards (5). The most important drawback of this grading system is that severe structural pulmonary vascular changes (grade 4 and higher) are unusual in the first two years of life, even in the presence of severely elevated pulmonary vascular resistance (6), which limits the value of this grading system.

Second, most studies using the morphometric approach to evaluate structural pulmonary vascular changes express the medial wall thickness as a percentage of the external diameter $(1,2,4,7,8)$. This parameter does not adequately reflect changes in medial cross-sectional area and lumen area, since the external diameter may change during the complex process of pulmonary vascular remodeling. In Mulvany's description of remodeling of arteries the ratio of media area to lumen area and the lumen area rather than medial wall thickness are essential parameters (9). A prerequisite for the analysis of structural pulmonary vascular changes as suggested by Mulvany and co-workers is that the analysis is performed under standard intravascular pressure and maximal vasodilatation. At autopsy or open lung biopsies it is technically almost impossible to process lung tissue and pulmonary arteries under these conditions. This limits the value of morphometric analysis of pulmonary arteries in open lung biopsies.

Third, even if morphometric analysis of structural pulmonary arterial changes is performed under standard intravascular pressure and maximal vasodilatation, we found, as described in chapter 3, for the rat hypoxia- and monocrotaline models of pulmonary hypertension, only limited correlations berween changes in pulmonary artery structure and changes in pulmonary artery pressure.

Medial thickening and muscularization of arterioles in children with congenital heart disease, however, was associated with perioperative hypertensive crisis. Moreover, patients with plexiform lesions showed persistent pulmonary hypertension after surgery.

It is known that medial thickening and muscularization of arterioles is associated with increased pulmonary contractile responses (10). Constriction rather than structural lumen narrowing of pulmonary arteries may therefore be the major determinant of an increased pulmonary artery pressure. In children with congenital heart disease and in animal models of pulmonary hypertension, morphometric paramerers and/or grading systems of structural pulmonary vascular changes do not take into account this functional component of the pulmonary vascular endothelium and smooth muscle cells. The hypothesis that may be derived from these data is that the muscularized arterioles constitute an important determinant of pulmonary artery pressure as a result of chronic hypoxia or in children with congenital heart disease. This is not only based on the data in children with congenital heart disease, where we found a positive correlation between muscularization of arterioles and hypertensive crises, but 
also on the data obtained from the rat studies, where chronic hypoxia and MCT increased both the number of muscularized arterioles and pulmonary artery pressure. Also during ACE inhibition, which did not affect pulmonary artery pressure, a substantial number of arterioles remained muscularized. Finally, in chronic hypoxic mice with a genetic disruption of the $A C E$ gene, the majority of arterioles remained muscularized while the right ventricular pressure was not affected.

\subsection{ROLE OF AII IN HYPOXIA-INDUCED PULMONARY HYPERTENSION AND RIGHT VENTRICULAR HYPERTROPHY}

AII is produced in the lungs through the conversion of angiotensin I (AI) into AII by $\mathrm{ACE}$. AII induces vasoconstriction, and is known to induce structural arterial changes like-matrix protein synthesis and smooth muscle cell hypertrophy and proliferation (11-15). In hypoxia-induced pulmonary hypertension in rats, local ACE expression is increased in the wall of small pulmonary arteries and right ventricular ACE expression is upregulated $(16,17)$. ACE inhibition in rats, in part reverses established hypoxia-induced pulmonary hypertension probably via inhibition of pulmonary vascular smooth muscle cell proliferation and/or growth (18).

From the data described in chapters 3 and 4, where we lowered the activity of $A C E$ by a pharmacologic (ACE inhibitor) or genetic intervention (tissue ACEdeficient mice) (19) we conclude that $\mathrm{ACE}$, and therefore also AII, plays a role in hypoxia-induced pulmonary vascular remodeling, but not in the development of pulmonary hypertension and right ventricular hypertrophy. In theory, alternative AII generating pathways, like AII formation by chymase, could play a role in constriction of partially muscularized arterioles and/or in the development of right ventricular hypertrophy (20).

Our first conclusion from these data is that the effect of a lowered ACE activity on the pulmonary vascular structure is a direct one, and nor due to an effect on pulmonary artery pressure. AII is known to stimulate proliferation of human pulmonary artery smooth muscle cells via the angiotensin type 1 receptor (21). Recent data suggest that AII also induces muscularization of arterioles in the chick embryo chorio-allantoic membrane (thesis le Noble 1997). The reduction of the percentage of completely muscularized arterioles in our animal models is most likely a result of inhibition of pulmonary vascular smooth muscle cell proliferation and/or growth, as suggested by Nong and co-workers (18). Recent data show that hypoxia-inducible factor l (HIF-1) is an important mediator of transcriptional responses to decreased oxygen availability. Several hypoxia-inducible genes like those encoding erythropoietin, vascular endothelial growth factor, inducible nitric oxide synthase, and endothelin-1 contain functionally important HIF-1 binding sites (22). Whether the ACE gene contains a HIF-1 binding site or affects the expression of HIF-1 in any other way is at this moment unknown and warrants further investigation. 
Second, these data show that despite a reduction of the percentage of completely muscularized arterioles there was no effect on pulmonary artery pressure/mean right ventricular pressure or right ventricular hypertrophy. As suggested above, constriction of parrially muscularized arrerioles may obscure effects of a reduced percentage of completely muscularized arterioles on the pulmonary artery and/or right ventricular pressure and right ventricular hypertrophy.

Also in patients with COPD and secondary pulmonary hypertension most studies report that treatment with ACE inhibitors does not improve survival and has no clinically significant effect on pulmonary hemodynamics (23-26). A possible explanation for the lack of effect of ACE inhibitors alone could be that, as we have shown in chronic hypoxic rats and mice, attenuation of this pulmonary vascular remodeling process alone is not enough to attenuate pulmonary artery pressure and right ventricular hypertrophy probably because of a persistent vasoconstrictive component. In theory, optimal treatment of pulmonary hypertension in patients with COPD should include a selective pulmonary vasodilator to attenuate the pulmonary vasoconstrictive component in combination with an ACE inhibitor to attenuate the development of structural pulmonary vascular changes. Indeed, oxygen, a potent pulmonary vasodilator, in combination with the ACE inhibitor captopril has been shown to reduce the pulmonary artery pressure and improved tissue oxygenation, although this study was based on 5 patients only (27).

\subsection{POTENTIAL ROLE OF GENE POLYMORPHISMS IN HYPOXIA-INDUCED PULMONARY HYPERTENSION}

COPD is a complex disease and likely results from a complex interplay between genetic and environmental factors. Polymorphisms of genes, like the polymorphisms of the $\alpha_{1}$-antitrypsin gene may be associared with alrered susceptibility to disease, to disease severity, and to the response to treatment $(28,29)$. Also a genetic predisposition in some instances of primary pulmonary hypertension (PPH) has been described, since a familial form of PPH is characterized by linkage to chromosome $2 \mathrm{q} 31-\mathrm{q} 32$ (30).

In the systemic circulation polymorphisms of genes of the RAS and eNOS are associated with an increased risk to cardiovascular diseases (31-38). With respect to the pulmonary circulation, very few data exist on a potential association between polymorphisms of genes of the RAS and $\mathrm{eNOS}$ and pulmonary hypertension, right ventricular hypertrophy and right ventricular function (39).

In chapters 5 and 6 , we therefore investigated potential associations between polymorphisms of the angiotensinogen gene, the ACE gene, the angiotensin type I receptor gene (chapter 5 ) and the eNOS gene (chapter 6 ) and electrocardiographic evidence of right ventricular hypertrophy. We have shown that the ACE DD polymorphism, but not the $A G T_{1} R, A G T$ and $\mathrm{NOS}$ polymorphisms, are negatively associated with electrocardiographic evidence of right ventricular hypertrophy in male patients 
with COPD. Right ventricular hypertrophy in our studies was determined by electrocardiographic criteria which is a specific but rather insensitive method. We were therefore unable to discriminate whether male patients with COPD and the ACE DD genorype had lower pulmonary arterial pressures or showed less adaprive right ventricular hypertrophy than did male patients with the non-DD genotype. Data of a recent study by Morrell and coworkers (40) show that people with hypoxia-induced pulmonary hypertension who were living at high altitude had a 6-fold higher frequency of the ACE II genotype compared with those without. Based on these findings we believe that it is more likely that in our study patients with COPD and the ACE DD genotype have lower pulmonary arterial pressures and as a consequence show less right ventricular hypertrophy than do patients with COPD with the non-DD genotype. Our data in the rat (chapter 3 ) and the mouse (chapter 4), however, suggest that pulmonary artery pressure will not be affected. The pulmonary artery pressures in the study of Morrell were measured during right heart catheterization. Future studies using the non-invasive and sensitive echo-doppler technique (41) to determine pulmonary artery pressure may provide a definitive answer to the question whether pulmonary artery pressures are changed in male COPD patients with the $\mathrm{DD}$ genotype.

Gender and susceptibility to develop pulmonary hypertension in patients with COPD

The negative association between the ACE DD genotype and electrocardiographic evidence of right ventricular hypertrophy was only present in male but nor in femalc patients with COPD. It is known that the female sex is a cardioprotective factor and that estrogens modulate the development of cardiac hypertrophy (42). As most femile patients with COPD in our study were postmenopausal, estrogens may mask or delay a potential association between the ACE genotype and right ventricular hypertrophy in female patients with COPD. Indeed several papers show that female sex hormones protect against pulmonary vascular remodeling and right ventricular hypertrophy in both hypoxia and MCT induced pulmonary hypertension $(43,44)$. In the study of Morrell (40), who showed that hypoxia-induced pulmonary hypertension had a 6-fold higher frequency of the ACE II genorype compared with those without, only males were included and it therefore provides no further evidence for a gender difference with respect to the ACE genotypes and development of pulmonary hypertension and/or right ventricular hypertrophy as we have shown in our study in patients with COPD. 


\subsection{CONCLUSIONS AND FUTURE PERSPECTIVES}

In conclusion, we found limited correlations between structural pulmonary vascular changes and pulmonary artery pressure. The best candidate that may improve the structure-function correlation in the lungs is the muscularized arteriole.

Second, angiotensin II plays a crucial role in the development of hypoxiainduced pulmonary vascular remodeling, but not in the development of pulmonary hypertension and right ventricular hypertrophy. The exact pathway how angiotensin II induces changes in pulmonary artery structure is not known. HIF-1 could be an important mediator in these hypoxia-induced structural pulmonary vascular changes.

Third, the ACE DD genotype was negatively associated with electrocardiographic evidence of right ventricular hypertrophy, but only in male patients with COPD. Analysis of polymorphisms of genes of vasoactive mediators may play an important role in the risk stratification and medical management of pulmonary hypertension in patients with congenital heart disease and COPD. The finding of gender differences in the susceptibility of patients with COPD for the development of right ventricular hypertrophy may also open up new strategies for therapy.

\section{REFERENCES}

1. Rabinovitch M, Haworth SG, Castaneda AR, Nadas AS, Reid LM. Lung biopsy in congenital heart disease: a morphometric approach to pulmonary vascular disease. Circulation 1978;58:1107-1122.

2. Haworth SG. Pulmonary vascular bed in children with complete atrioventricular septal defect: Relation between structural and hemodynamic abnormalities. Am. J. Cardiol. 1986;57:833-839.

3. Haworth SG. Pulmonary vascular disease in ventricular sepral defect: Structural and functional correlations in lung biopsies from 85 patients, with outcome of intracardiac repair. J. Pathol 1987;152:157-168.

4. Bush A, Busst CM, Haworth SG, Hislop AA, Knight WB, Corrin B, Shinebourne EA. Correlations of lung morphology, pulmonary vascular resistance, and outcome in children with congenital heart disease. Br. Heart J. 1988:59:480-485.

5. Heath D, Edwards J. The pathology of hypertensive pulmonary vascular disease. A description of six grades of structural changes in the pulmonary arteries with special reference to congenital cardiac septal defects. Circulation 1958;18:533-547.

6. Wagenvoort CA, Nauta J. The pulmonary vasculature in complete transposition of the great vessels judged from lung biopsies. Circulation 1968:38:746-754.

7. Haworth SG, Reid L. A morphometric study of regional variation in lung structure in infants with pulmonary hypertension and congenital cardiac defect. A justification of lung biopsy. Br. Heart J. 1978;40:825-831. 
8. Haworth SG. Pulmonary vascular disease in different types of congenital heart disease Implications for interpretation of lung biopsy findings in early childhood. Br. Heart J. 1984;52:557-571.

9. Mulvany MJ, Baumbach GL, Aalkjaer C, Heagerty AM, Korsgaard N, Schiffrin EL, Heistad DD. Vascular remodeling. Hypertension 1996;28:505-506.

10. Haworth SG, Radley-Smith R, Yacoub M. Lung biopsy findings in transposition of the great arteries with ventricular septal defect: porentially reversible pulmonary vascular disease is not always synonymous with operability. I. Am. Coll. Cardinl. 1987;9:327-333.

11. Geisterfer AAT, Peach MJ, Owens GK. Angiutensin II induces hypertrophy, not hyper plasia, of cultured rat aortic smooth muscle cells. Circ. Res. 1988;62:749-756.

12. Scott-Burden T, Hahn AWA, Resink TJ, Buhler FR. Modulation of extracetlular matrix by angiotensin II: Stimulated glycoconjugate synthesis and growth in vascular smooth muscle cells. J. Cardiovasc. Pharmacol 1990;16(Suppl. 4):S36-S41.

13. Chiu AT, Roscoe WA, McCall DE, Timmermans PB. Angiotensin II-1 receptors mediate both vasoconstrictor and hypertrophic responses in rat aortic smooth muscle cells. Receptor 1991;1:133-140.

14. Daemen MJ, Lombardi DM, Bosman FT, Schwartz SM. Angiotensin II induces smooth muscle cell proliferation in the normal and injured rat arterial wall. Circ. Res. $1991 ; 68: 450-456$.

15. Gibbons GH, Pratt RE, Dzau VJ. Vascular smooth muscle cell hypertrophy vs. hyperplasia. Autocrine transforming growth factor-beta 1 expression determines growth response to angiotensin II. J. Clin. Invest. 1992;90:456-461.

16. Morrell NW, Atochina EN, Morris KG, Danilov SM, Stenmark KR. Angiotensin converting enzyme expression is increased in small pulmonary arteries of rats with hypoxia-induced pulmonary hypertension. J. Clin. Invest. 1995;96:1823-1833.

17. Morrell NW, Danilov SM, Satyan KB, Morris KG, Stenmark KR. Right ventricular angiotensin converting enzyme activity and expression is increased during hypoxic pulmonary hypertension. Cardiovasc. Res. 1997;34:393-403.

18. Nong Z, Stassen J-M, Moons L, Collen D, Janssens S. Inhibition of tissue angiotensinconverting enzyme with quinapril reduces hypoxic pulmonary hypertension and pulmonary vascular remodeling. Circulation 1996:94:1941-1947.

19. Esther CR, Marino EM, Howard TE, Machaud A, Corvol P, Capecchi MR, Bernstein $\mathrm{KE}$. The critical role of tissue angiotensin-converting enzyme as revealed by gene targeting in mice. J. Clin. Invest. 1997;99:2375-2385.

20. Daemen MJ, Urata $H$. Healing human myocardial infarction associated with increased chymase immunoreactivity. Heart Vessels 1997:Suppl 12:113-115.

21. Morrell NW, Upton PD, Higham MA, Yacoub MH, Polak JM, Wharron J. Angiotensin II stimulates proliferation of human pulmonary artery smooth muscle cells via the AT1 receptor. Chest 1998;114(Suppl):90S-91S.

22. Yu AY, Shimoda LA, Iyer NV, Huso DL, Sun X, McWilliams R, Beaty T, Sham JS, Wiener CM, Sylvester JT, Semenza GL. Impaired physiological responses to chronic 
hypoxia in mice partially deficient for hypoxia-inducible factor lalpha. J. Clin. Invest. 1999;103:691-696.

23. Bertoli L, Lo Cicero S, Busnardo I, Rizzato G, Montanari G. Effects of captopril on hemodynamics and blood gases in chronic obstructive lung disease with pulmonary hypertension. Respiration 1986;49:251-256.

24. Zielinski J, Hawrylkiewicz I, Gorecka D, Gluskowski J, Koscinska M. Captopril effects on pulmonary and systemic hemodynamics in chronic cor pulmonale. Chest 1986;90:562-565.

25. Patakas D, Georgopoulos D, Rodini H, Christaki P. Effects of captopril in patients with chronic obstructive pulmonary disease and secondary pulmonary hypertension. Postgrad. Med. J. 1988;64:193-195.

26. Pison CM, WolfJE, Levy PA, Dubois F, Brambilla CG, Paramelle B. Effects of captopril combined with oxygen therapy at rest and on exercise in patients with chronic bronchitis and pulmonary hypertension. Respiration 1991;58:9-14.

27. Burke CM, Harte M, Duncan J, Connolly HM, Horgan JH, Theodore J, Callaghan B. Captopril and domiciliary oxygen in chronic airflow obstruction. Br. Med. J. 1985;290:1251.

28. Poller W, Meisen C, Olek K. DNA polymorphisms of the alpha 1-antitrypsin gene region in patients with chronic obstructive pulmonary disease. Eur. J. Clin. Invest. 1990;20:1-7.

29. Barnes PJ. Molecular genetics of chronic obstructive pulmonary disease. Thorax 1999;54:245-252.

30. Morse JH, Jones AC, Barst RJ, Hodge SE, Wilhelmsen KC, Nygaard TG. Mapping of familial primary pulmonary hypertension locus (PPH1) to chromosome $2 \mathrm{q} 31-\mathrm{q} 32$. Girculation 1997;95:2603-2606.

31. Cambien F, Poirier O, Lecerf L, Evans A, Cambou JP, Arveiler D, Luc G, Bard JM, Bara L. Ricard S, Tiret L, Amouyel P, Alhenc-Gelas F, Soubrier F. Deletion polymorphism in the gene for angiorensin-converting enzyme is a potent risk factor for myocardial infarction. Nature 1992;359:641-644.

32. Bonnardeaux A, Davies E, JeunemaitreX, Fery I, Charru A, Clauser E, Tirer L, Cambien $\mathrm{F}$, Corvol P, Soubrier F. Angiotensin II type 1 receptor gene polymorphisms in human essential hypertension. Hypertension 1994;24:63-69.

33. Tiret L, Bonnardeaux A, Poirier O, Ricard S, Marques-Vidal P, Evans A, Arveiler D, Luc G. Kee F, Ducimeriere P, Soutrier F, Cambien F. Synergistic effects of angiotensinconverting enzyme and angiotensin-II type 1 receptor gene polymorphisms on risk of myocardial infarction. Lancet 1994:344:910-913.

34. Schunkert H, Hense HW, Holmer SR, Stender M, Perz S, Keil U, Lorell BH, Riegger GA. Association between a deletion polymorphism of the angiotensin-convertingenzyme gene and left ventricular hypertrophy. N. Engl.J. Med. 1994:330:1634-1638.

35. Benetos A, Gaurier S, Ricard S, Topouchian J, Asmar R, Poirier O, Larosa E, Guize L, Safar M, Soubrier F, Cambien F. Influence of angiotensin-converting enzyme and 
angiotensin II type 1 receptor gene polymorphisms on aortic stiffness in normotensive and hypertensive patients. Circulation 1996;94:698-703.

36. Katsuya T, Koike G, Yee TW, Sharpe N, Jackson R, Norton R, Horiuchi M, Prat RE, Dzau V], MacMahon S. Association of angiotensinogen gene T235 variant with increased risk of coronary heart disease. Lancet 1995;345:1600-1603.

37. Hibi K, Ishigami T, Tamura K, Mizushima S, Nyui N, Fujita T, Ochiai H, Kosuge M, Watanabe Y, Yoshii Y, Kihara M, Kimura K, Ishii M, Umemura S. Endothelial nitric oxide synchase gene polymorphism and acute myocardial infarction. Hypertension 1998;32:521-526.

38. Miyamoto Y, Saito Y, Kajiyama N, Yoshimura M, ShimasakiY, Nakayama M, Kamitani S, Harada M, Ishikawa M, Kuwahara K, Ogawa E, Hamanaka I, Takahashi N, Kaneshige T, Teraoka H, Akamizu T, Azuma N, Yoshimasa Y, Yoshimasa T, Itoh H, Masuda 1, Yasue H, Nakao K. Endothelial nitric oxide synthase gene is positively associated with essential hypertension. Hypertension 1998;32:3-8.

39. Abraham WT, Raynolds MV, Gotrschall B, Badesch DB, Wynne KM, Groves BM, Lowes BD, Bristow MR, Perryman MB, Voelkel NF. Importance of angiorensinconverting enzyme in pulmonary hypertension. Cardiology 1995;86 Suppl 1:9-15.

40. Morrell NW, Sarybaev AS, Alikhan A, Mirrakhimov MM, Aldashev AA. ACE genotype and risk of high altitude pulmonary hypertension in Kyrghyz highlanders. Lancet 1999;353:814.

41. Berger M, Haimowiz A, Van Tosh A, BerdoffRL, Goldberg E. Quantitative assessment of pulmonary hypertension in patients with tricuspid regurgitation using continuous wave Doppler ultrasound. J. Am. Coll. Cardiol. 1985;6:359-365.

42. Grohe C, Kahlert S, Lobbert K, Meyer R, Linz KW, Karas RH, Verter H. Modulation of hypertensive heart disease by estrogen. Steroids 1996;61:201-204.

43. Farhat MY, Chen MF, Bhatri T, Iqbal A, Cathapermal S, Ramwell PW. Protection by oestradiol against the development of cardiovascular changes associated with monocroraline pulmonary hypertension in rats. Br. J. Pharmacol. 1993:110:719-723.

44. Ou LC, Sardella GL, Leiter JC, Brinck-Johnsen T, Smirh RP. Role of sex hormones in development of chronic mountain sickness in rats. J. Appl. Physiol. 1994;77:427-33. 


\section{Summary}

Pulmonary hypertension is a common complication of cardiopulmonary diseases. All patients with chronic pulmonary hypertension, irrespective of the etiology, have structural pulmonary vascular changes, commonly called pulmonary vascular remodeling. The pathogenesis of pulmonary vascular remodeling in patients with chronic obstructive pulmonary disease (COPD) and in children with congenital heart disease is poorly understood. Moreover, discrepancies between pulmonary hemodynamics and pulmonary artery structure have been described in children with congenital heart disease and animal models of pulmonary hypertension. In this thesis, experiments were performed to study the role of angiotensin II (AII) in hypoxia-induced pulmonary vascular remodeling as occurs in patients with COPD. Furthermore, we studied the correlation between pulmonary vascular remodeling and pulmonary artery pressure. Finally, we studied the role of polymorphisms of genes of the renin angiotensin system (RAS) and endothelial nitric oxide synthase (eNOS) in the development of pulmonary hypertension in patients with severe COPD.

In chapter 2 we determined the correlation between pulmonary hemodynamics, structural pulmonary arterial changes and outcome in 47 children with congenital heart disease. Structural pulmonary arterial changes were evaluated in open lung biopsies or in lung tissue obtained at autopsy. We found only limited correlations between hemodynamic data and structural pulmonary vascular changes. Perioperative mortality, associated with acute pulmonary hypertensive crises, positively correlated with increased arterial muscularity, but could not be predicted from preoperative hemodynamics or the presence of advanced plexogenic arteriopathy. Only plexiform lesions were predictive for persistent pulmonary hypertension.

In chapter 3 we correlated structural pulmonary vascular changes of muscular pulmonary arteries and arterioles in chronic hypoxic and monocrotaline (MCT) treated rats with pulmonary artery pressure and right ventricular hypertrophy. Discrepancies between pulmonary artery pressure and pulmonary artery structure may be explained by the fact that constriction, rather than structural narrowing of pulmonary arteries, plays a role in the rise of the pulmonary artery pressure. We therefore performed morphometrical analysis on pulmonary arteries fixed under standard intravascular pressure and maximal vasodilatation. An alternative explanation for discrepancies between pulmonary artery pressure and pulmonary artery structure is that previous studies have focussed on the wrong parameters of structural pulmonary vascular changes. The medial wall thickness expressed as a percentage of the arterial external diameter does not adequately reflect changes in medial cross-sectional area and lumen area since the external diameter of arteries may also changes during the process of vascular remodeling. Therefore, morphometrical analysis of structural pulmonary vascular changes was performed according to the concepe of Mulvany in which the 
media area to lumen area ratio and lumen area are essential parameters, rather than medial wall thickness. We observed thar MCT, in contrast to chronic hypoxia, induces structural changes of muscular pulmonary arteries which may contribure to an increase in pulmonary artery pressure and right ventricular hypertrophy. The ACE inhibitor captopril had no effect on MCT-induced pulmonary hypertension, right ventricular hypertrophy and pulmonary artery remodeling. In chronic hypoxic rats, however, captopril prevented an increase in medial cross-sectional area of muscular pulmonary arteries and attenuated the increase in the percentage of muscularized arterioles, without any effect on pulmonary artery pressure and right ventricular hypertrophy.

In chapter 4 we investigated the effects of chronic hypoxia on pulmonary vascular remodeling and its functional consequences in tissue ACE-deficient mice. Under chronic hypoxic conditions the percentage of completely muscularized arterioles was lower in tissue ACE-deficient mice compared to wild-type animals whereas the mean right ventricular pressure and the extent of right ventricular hypertrophy was not different. We concluded that pulmonary vascular remodeling is attenuated in tissue ACE-deficient mice compared to wild-type animals. Local production of angiotensin II by ACE in pulmonary arterioles plays an important role in the pathogenesis of hypoxia-induced pulmonary vascular remodeling.

In chapters 5 and 6 we studied the potential role of polymorphisms of genes of the renin angiotensin system (RAS) and endothelial nitric oxide synthase (eNOS) in the development of pulmonary hypertension induced right ventricular hypertrophy in patients with severe COPD. Polymorphisms of the RAS included the $\mathrm{M}^{235} \mathrm{~T}$ polymorphism of the angiorensinogen gene, the 287 base-pair insertion (I)/ deletion (D) polymorphism at intron 16 of the $\mathrm{ACE}$ gene and the $\mathrm{A}^{1106} \mathrm{C}$ polymorphism in the angiotensin II type 1 receptor gene. The eNOS gene polymorphisms included a guanine to thymine substitution within exon 7 and a 27 base-pair repeat polymorphism in the fourth intron of the $\mathrm{NOS}$ gene. We observed that only the ACE DD genotype was negatively associated with electrocardiographic evidence of right ventricular hypertrophy but only in male patients with COPD. The other polymorphisms investigated did nor show an association with electrocardiographic evidence of right ventricular hypertrophy.

Finally, in chapter 7 the results are discussed and the main conclusions of this thesis are summarized. 


\section{Samenvatting}

Pulmonale hypertensie is een veel voorkomende en soms levensbedreigendt cumplicatie die kan optreden bij kinderen met een aangeboren hartafwijking waarbij er sprakc is van een toegenomen bloeddoorstroming door de longarteriën en pariënten mer chronisch obstructief longlijden (COPD). Patiënten met chronische pulmonalc hypertensie hebben, onafhankelijk van de oorzaak, structurele longvaatveranderingen; afwijkingen die ook wel omschreven worden als remodellering van de longvaatwand. De pathogenese van dit remodelleringsproces is niet bekend. Bovendien zijn er discrcpanties beschreven tussen structurele longvaatveranderingen bij kinderen met een aangeboren hartafwijking en drukken gemeten in deze longarteriën. In dit proefschrift worden experimenten beschreven met als doel om meer inzicht te krijgen in de regulatic van dit remodellerings proces van longarteriën. Allereerst hebben we de resultaten van hemodynamische evaluatie en structurele longvaatveranderingen met elkaar vergeleken in zowel diermodellen voor pulmonale hypertensie alsmede in kinderen mer een aangeboren hartafwijking. Vervolgens wordt de rol van angiotensine II (AII) bestudeerd in dit remodellerings proces. Tenslotte, wordt de rol van varianten (polymorfismen) van genen van het renine angiotensine systeem en endotheliaal stikstofoxide synthase ( $\mathrm{eNOS}$ ) bestudeerd in relatie tot de ontwikkeling van pulmonale hypertensie bij patiënten met COPD.

In hoofdstuk 2 werden hemodynamische gegevens gecorreleerd met structurele longvaatveranderingen en het klinisch beloop van 47 kinderen met een aangeboren hartafwijking.

Longvaarveranderingen werden bestudeerd in open longbiopten of longweefsel verkregen bij obductie. Er bleek sprake te zijn van een slechte correlatie tussen hemody. namische parameters en structurele longvaatveranderingen. Perioperatieve mortalitcit, geassocieerd mer zogenaamde pulmonale hypertensieve crisen, bleck positief te curreleren met een toegenomen verdikking van de wand van longarteriën en arteriolen. Peri operatieve mortaliteit kon echter niet worden voorspeld op grond van preoperatieve hemodynamische gegevens en/of structurele longvaatveranderingen in een vergevorderd stadium.

Alleen de aanwezigheid van zogenaamde plexiforme afwijkingen van longarreriën was in alle gevallen geassocieerd met het persisteren van pulmonale hypertensie.

De correlatie tussen structurele longvaatveranderingen en de druk in de longarteriën en rechter ventrikelwand hypertrofie werd beschreven in hoofdstuk 3. De experimenten werden uitgevoerd in een tweetal veelvuldig gebruikte ratten modellen, te weten het chronische alveolaire hypoxie model en het door monocrotaline (MCT) geïnduceerde pulmonale hypertensie model. Een mogelijke oorzaak van discrepanties tussen structurele longvaatveranderingen en hemodynamische gegevens zou gelegen kunnen zijn in het feit dat morfometrische analyse van longvaatveranderingen nier 
onder optimale perfusie condities werd uitgevoerd. Doel van dit onderzoek was het om structurele longvaatveranderingen te bestuderen onder gestandaard iseerde omstandigheden. Morfometrie werd verricht nadat de longvaten waren gefixeerd onder maximale vaatverwijding en standaard druk. Bovendien werden parameters als de ratio media oppervlakre/lumen oppervlakte en lumen oppervlakte gebruikt, daar deze parameters de gevolgen van het remodellerings proces voor de vaatwand nauwkeuriger weergeven. De in de literatuur veel gebruikte ratio media dikte/vaatwand diameter is een minder nauwkeurige parameter, omdat tijdens het remodellerings proces van de vaatwand de diameter van het vat ook kan veranderen. Morfometrische analyse uitgevoerd onder deze omstandigheden toonde aan dat alleen MCT geïnduceerde media verdikking van longarteriën resulteerde in een reductie van het lumen oppervlak. Een tweede doel van het in hoofdstuk 3 beschreven onderzoek was het bestuderen van de rol van AII in het remodellerings proces. De angiotensine I converting enzyme remmer captopril had geen invloed op MCT geïnduceerde structurele longvaatveranderingen, de mate van pulmonale hypertensie en de mate van rechter ventrikelwand hypertrofie. Onder chronische hypoxische omstandigheden voorkwam captopril vaatwandverdikking van musculaire longarteriën en verminderde het aantal gemusculariseerde arteriolen, echter zonder effect op de druk in de longarteriën en zonder effect op de mate van rechter ventrikelwand hypertrofie.

In hoofdstuk 4 werden de effecten van chronische hypoxie beschreven op her remodellerings proces van arteriolen in genetisch gemanipuleerde (weefsel AC'E-deficiënte) muizen. Onder chronische hypoxische omstandigheden was her percentage arteriolen dat volledig omgeven was door een laag gladdespiercellen (gemuscularizeerde arteriolen) lager in weefsel ACE-deficiënte muizen vergeleken met de controle groep. De minder uirgesproken remodellering van arteriolen in weefsel ACE deficiënte muizen had echter geen invloed op drukken in longarteriën en op de mate van rechter ventrikelwand hypertrofie. Uit deze studie kan worden geconcludeerd dat locale productie van AII door ACE in longarteriolen een belangrijke rol speelt bij de pathogenese van chronische hypoxie-geïnduceerde remodellering van deze arteriolen.

In de hoofdstukken 5 en 6 werd de rol van varianten (polymorfismen) van genen van het renine angiotensine systeem (RAS) en endotheliaal stikstofoxide synthase (eNOS) bestudeerd bij het ontstaan van, door pulmonale hypertensie geïnduceerde, rechter ventrikelwand hypertrofie bij patiënten met COPD. Verschillende varianten van genen het het RAS werden geanalyseerd. Her betrof een thymine/cytosine-puntmutatie op positie 704 van exon 2 van het angiotensinogeen gen leidende tot een aminozuur substitutie waarbij methionine op positie 235 vervangen wordt door threonine ( $\mathrm{M}^{235} \mathrm{~T}$-variant), een 287 baseparen insertie (I)/deletie (D) variant in intron 16 van het $A C E$ gen en een $A^{1166} \mathrm{C}$ variant in het gen coderend voor de angiotensine II type 1 receptor waarbij op positie 1166 de base adenine vervangen is door cytosine. Varianten van het eNOS gen waren een guanine/thymine substitutie in exon 7 ( $\mathrm{eNOS} \mathrm{G} / \mathrm{T}$ ) en een 27 baseparen verschillende variant in intron $4(\mathrm{eNOS} \mathrm{a} / \mathrm{b})$. Electrocardiografische criteria werden gebruikt om 
eventuele rechterventrikelwand hypertrofie aan te tonen. $\mathrm{Bij} 36 \%$ van de patiënten met COPD bleek er sprake te zijn van rechterventrikelwand hypertrofie. Van alle onderzochte varianten van genen van het RAS en $\mathrm{eNOS}$ kon alleen een negatieve associatie worden aangetoond tussen mannelijke patiënten mer COPD met het ACE DD genotype en rechterventrikelwand hypertrofie.

Tenslotte worden in hoofdstuk 7 de resultaten van de hierboven beschreven hoofdstukken met elkaar in verband gebracht en worden er enkele suggesties gedaan om te komen tot een betere inventarisatie van structurele longvaatverandering en behandelingsmogelijkheden om deze structurele longvaatveranderingen te voorkomen of te verminderen. 


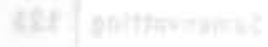




\section{Dankwoord}

Dit proefschrift is tot stand gekomen dankzij de unieke samenwerking tusscn medewerkers van de vakgroepen pathologie en farmacologie. Enkele mensen echter wil ik in het bijzonder bedanken:

Allereerst mijn promotor Mat Daemen. Beste Mat, snel, helder en vaak geniaal. Veel ideeën ontstonden tijdens een rondje Observant of Savelsbos. Dit is zowel het proefschrift als ook het lichaam ten goede gekomen.

Vervolgens mijn promotor Jos Smits. Beste Jos, kritisch, meedenkend en in combinatie met Mat uniek maar vaak wat lastig voor de kandidaat.

Prof. dr. C.A. Wagenvoort, die helaas kort na her tot stand komen van het eerst manuscript overleed. Een beter leermeester voor het leren beoordelen van longvaatveranderingen was er nier.

De leden van de beoordelingscommissie Prof. dr. J.G.R. De Mey, Prof. dr. C.E. Blanco, Prof. dr. P.W. de Leeuw. Prof. dr. W.J. Mooi en Dr. G.J. Wesseling wil ik bedanken voor het kritisch doorlezen van het manuscript.

Peet, Mo, An en Loes. DNA isoleren en PCR technieken leerden jullie me snel, echter her leren bereken van verdunningen duurde langer.

Jacques en Peter, in combinatie op het lab bijna net zo dodelijk als de combinatie Smits-Daemen. Nicole dank voor de hulp bij alle drukmetingen.

Emiel Wouters ben ik dank verschuldigd voor het tor stand komen van contacten mer het Astma Centrum Hornerheide. Herman-Jan Pennings bedankt voor de hulp bij her invoeren van patiëntengegevens en beiden bedankt voor het kritisch doorlezen van de manuscripten die hieruit voortkwamen.

Emile Cheriex en Petra van Pol voor het beoordelen van de ECG's. Het zal wel altijd "Petra van de P-toppen" blijven.

John Hess en Rolf Berger stonden misschien wel aan de basis van dit proefschrift. Zij hadden vanaf het begin een kritische houding ten aanzien van een relatie tussen longvaatstructuur en hemodynamische consequenties en naar later bleek deels terecht.

Cor Beek, Jack Cleurjens, Wendy Aartsen, Wilko Spiering, Jacques Baltis en mensen die ik vergeten ben dank voor de hulp met computers, morfometrie, polymorfismen, TWACE muizen, afbranden, etc.

De paranimfen en maten Rob Homburg en Joep Gerards.

Mijn schoonouders die me er van konden overtuigen om geneeskunde te gaan studeren.

Mijn vader voor alle "zerjes" in de rug vooral tijdens mijn middelbare schooltijd. Mijn moeder die als enige begreep dat de studie geneeskunde meer inhield dan de bloedsomloop van de kikker.

Tenslorte de ouwe Dibbes en de oelewappers: het viel eigenlijk allemaal wel mee! 



\section{Publications}

This thesis is based on the following papers

1. Berger RMF, van-Suylen RJ, van-Zuuren DAK, Wagenvoort CA, Mooi WJ, Bogers AJJC, Hess J. Evaluation of pulmonary hemodynamics and structure and their relation with clinical outcome in children with congenital heart disease. Submitted.

2. van-Suylen RJ, Smits JFM, Daemen MJAP. Pulmonary artery remodeling differs in hypoxia- and monocrotaline induced pulmonary hypertension. Am. J. Respir. Crit. Care Med. 1998;157:1423-1428.

3. van-Suylen RJ, Aartsen W, Smits JFM, Daemen MJAP. Dissociation of putmonary vascular remodeling and right ventricular pressure in tissue ACE-deficient mice in conditions of chronic alveolar hypoxia. Submitted.

4. van-Suylen RJ, Wouters EF, Pennings HJ, Cheriex EC, van-Pol PE, Ambergen AW, Vermelis A, Daemen MJ. The DD genotype of the angiotensin converting enzyme gene is negatively associated with right ventricular hypertrophy in male patients with chronic obstructive pulmonary disease. Am. J. Respir. Crit. Care Med. 1999;159:1791-1795.

5. van-Suylen RJ, Pennings HJ, Wouters EF, Cheriex EC, van-Pol PE, Ambergen AW, Spiering W, Aarts PL, Daemen MJAP. Endothelial nitric oxide synthase gene polymorphisms and right ventricular hypertrophy in pa tients with chronic obstructive pulmonary disease. Submitted.

Moreover, the author of this thesis is first author on 3 papers and co-author on 28 papers. 


\title{
Curriculum Vitae
}

\author{
Robert Jan van Suylen \\ 1957 \\ Geboren the Prabumulih (Indonesië) \\ 1976 \\ Eindexamen HAVO Hertog Jan College Valkenswaard \\ 1976 - 1980 Academie voor Lichamelijke Opvoeding KALO te Tilburg \\ 1980 - $1982 \quad$ Militaire Dienst \\ 1982 Staatsexamen Natuurkunde en Scheikunde \\ 1982 - 1988 Studie Geneeskunde Erasmus Universiteit Rotterdam \\ 1986 \\ Doctoraal examen Geneeskunde \\ 1988 \\ Artsexamen \\ 1988 - 1989 AGNIO Heelkunde Ac. Ziekenhuis Dijkzigt Rorterdam \\ 1989 - 1994 Opleiding Pathologie Ac. Ziekenhuis Dijkzigt Rotterdam \\ (Opleiders Prof. dr. R.O. van der Heul, Prof. dr. F.T. Bosman) \\ 1994 - 1995 Staflid afdeling pathologie Ac. Ziekenhuis Dijkzigt Rotterdam \\ 1995 - heden Staflid afdeling pathologie Ac. Ziekenhuis Maastricht
}



